\title{
Preliminary Evaluation of the Hydrogeologic System in Owens Valley, California
}

By Wesley R. Danskin

U.S. GEOLOGICAL SURVEY

Water-Resources Investigations Report 88-4003

Prepared in cooperation with INYO COUNTY and the

LOS ANGELES DEPARTMENT OF WATER AND POWER

ฟั๋

Sacramento, California 1988 


\author{
DEPARTMENT OF THE INTERIOR \\ DONALD PAUL HODEL, Secretary \\ U.S. GEOLOGICAL SURVEY \\ Dallas L. Peck, Director
}

For additional information write to:

District Chief

U.S. Geological Survey

Federal Building, Room W2234

2800 Cottage Way

Sacramento, CA 95825
Copies of this report

can be purchased from:

U.S. Geological Survey

Books and Open-File Reports Section

Box 25425, Building 810

Federal Center

Denver, CO 80225 


\section{CONTENTS}

Page

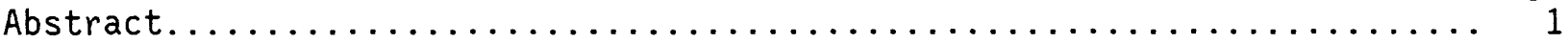

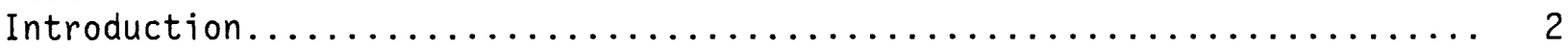

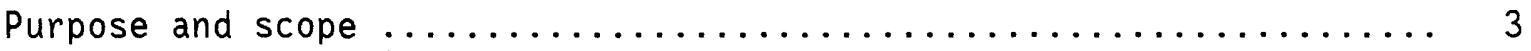

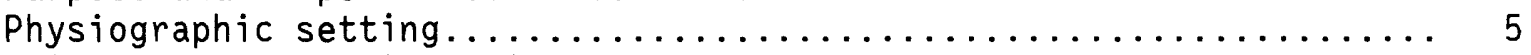

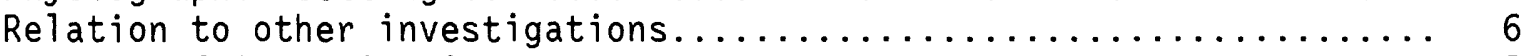

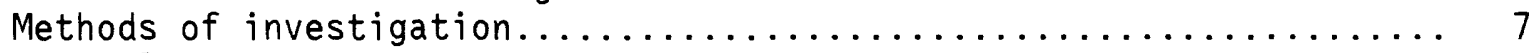

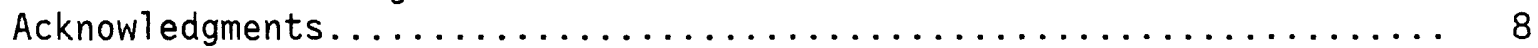

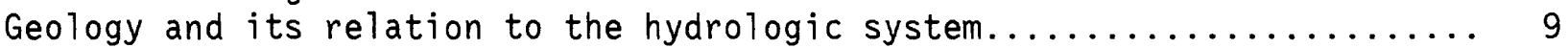

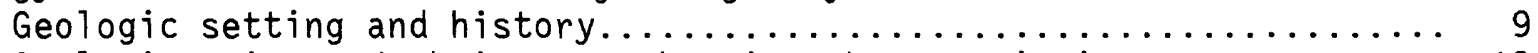

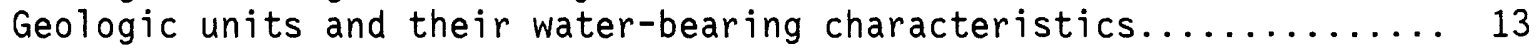

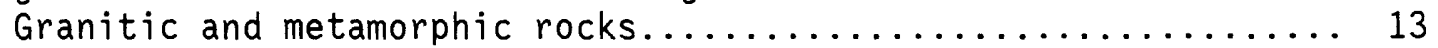

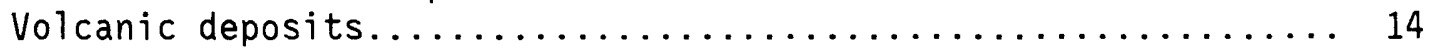

Alluvial deposits................................. 15

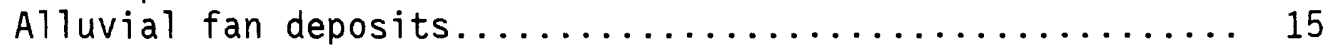

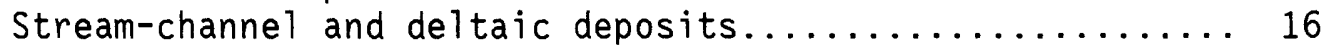

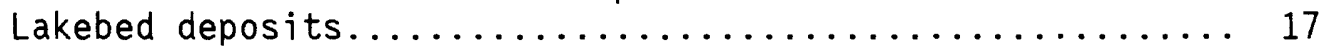

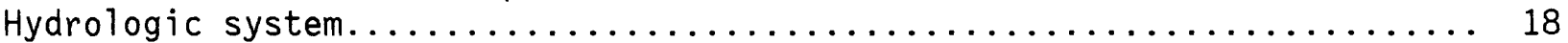

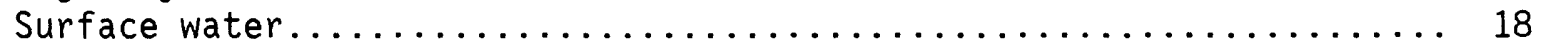

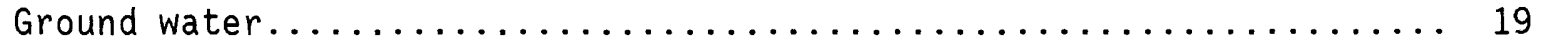

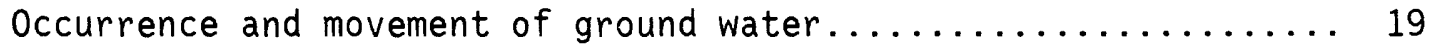

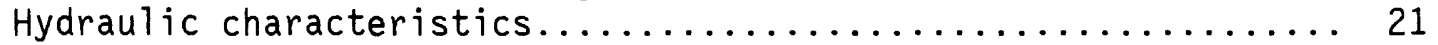

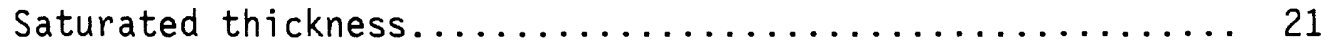

Hydraulic conductivity and transmissivity............. 24

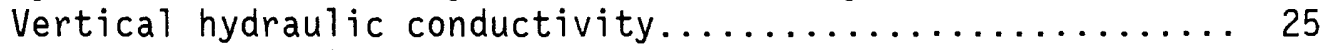

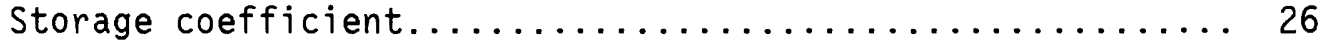

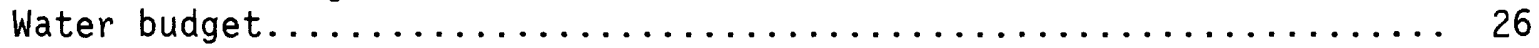

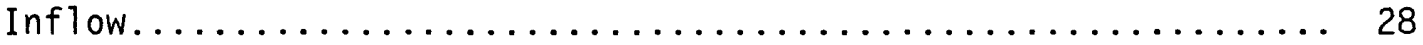

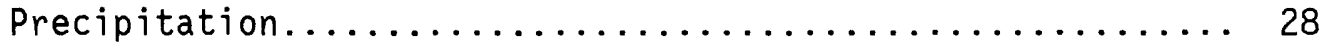

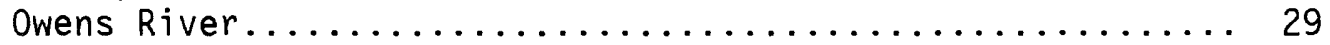

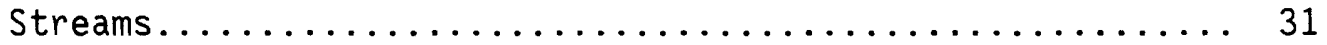

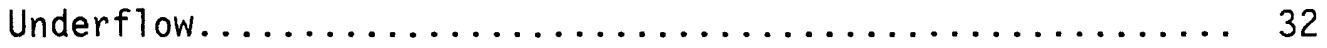

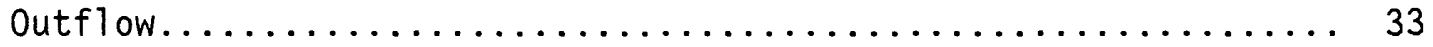

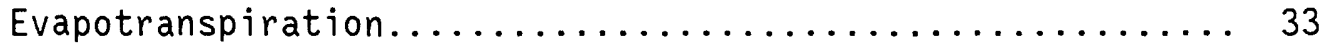

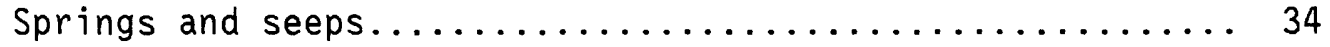

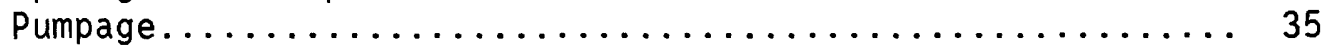

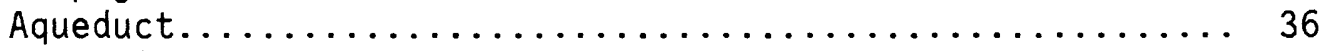

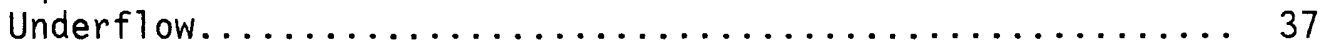

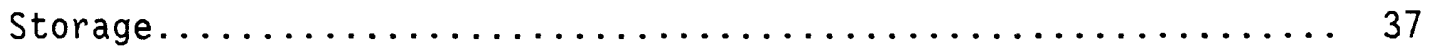

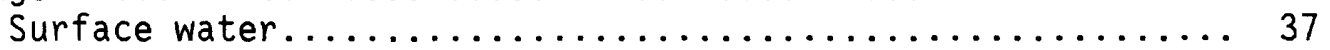

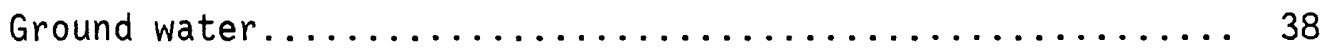

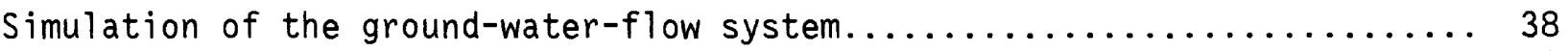

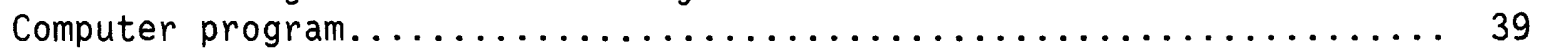

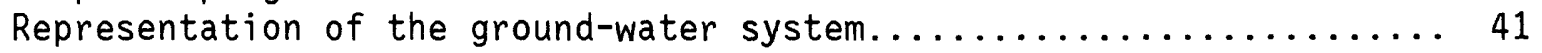

Model boundaries and layers.......................... 41

Areas with similar hydrogeologic characteristics............44

Methods of simulating aquifer recharge and discharge......... 46 
Simulation of the ground-water-flow system--Continued

Simulation of equilibrium conditions ........................ 51

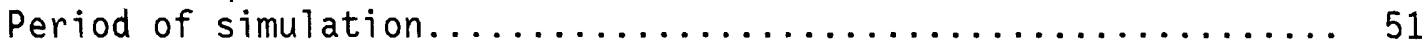

Model calibration.................................. 52

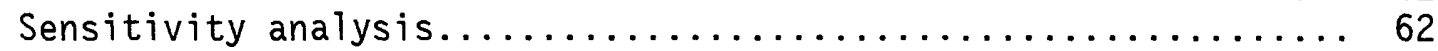

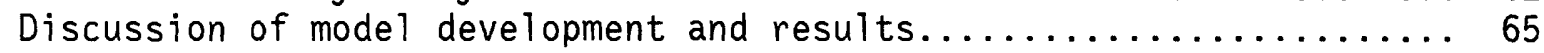

Findings from other ground-water-modeling studies in Owens Valley... 67

Need for future studies........................................ 70

Summary and conclusions $\ldots \ldots \ldots \ldots \ldots \ldots \ldots \ldots \ldots \ldots \ldots \ldots \ldots \ldots \ldots \ldots \ldots \ldots \ldots \ldots, 73$

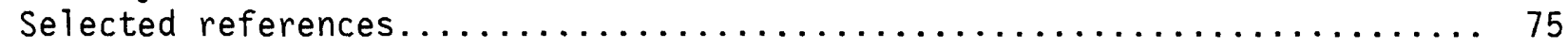

\section{ILLUSTRATIONS}

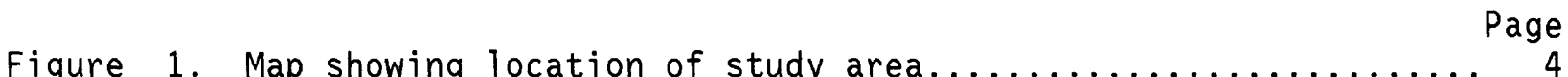

2. Map showing surficial geology of Owens Valiey................. 10

3. Typical geologic section of Owens Valley................ 12 4-9. Maps showing:

4. Contours of measured hydrautic heads for unconfined and confined zones............................ 22

5. Finite-difference grid and boundary conditions used for both layers of the ground-water-flow model......... 40

6. Areas of the ground-water model with similar hydrogeologic characteristics................. 44

7. Location of simulated stream recharge and ground-water pumpage, and constant-head conditions in the ground-water model......................... 48

8. Comparison of simulated and measured hydraulic heads for each layer of the ground-water model............... 58

9. Comparison of simulated and estimated rates of recharge and discharge for the Owens River, Los Angeles Aqueduct, and Tinemaha and Haiwee Reservoirs..........

\section{TABLES}

Table 1. Initial and calibrated values of model parameters for

different hydrogeologic categories.................... 53

2. Simulated steady-state budget for water years $1935-70 \ldots \ldots \ldots .53$

3. Initial and calibrated maximum evapotranspiration rates for different hydrogeologic categories..................... 55 


\section{CONVERSION FACTORS}

The inch-pound system of units is used in this report. For those readers who prefer metric (International System) units, the conversion factors for the terms used in this report are listed below:

Multiply inch-pound unit

acre

acre-foot (acre-ft)

acre-foot per year

(acre-ft/yr)

cubic foot per second $\left(\mathrm{ft}^{3} / \mathrm{s}\right)$

foot ( $f t)$

foot per day $(\mathrm{ft} / \mathrm{d})$

foot squared per day $\left(\mathrm{ft}^{2} / \mathrm{d}\right)$

foot per year (ft/yr)

foot per mile (ft/mi)

gallon per minute (gal/min)

inch (in.)

inch per year (in/yr)

mile (mi)

square mile $\left(m i^{2}\right)$
0.4047

0.001233

0.001233

0.02832

0.3048

0.3048

0.09290

0.3048

0.1894

0.00006309

25.4

25.4

1.609

2.590
To obtain metric unit

hectare

cubic hectometer

cubic hectometer per year

cubic meter per second meter

meter per day

meter squared per day

meter per year

meter per kilometer

cubic meter per

second

millimeter

millimeter per year

kilometer

square kilometer

Temperature is given in degrees Fahrenheit $\left({ }^{\circ} \mathrm{F}\right)$, which can be converted to degrees Celsius $\left({ }^{\circ} \mathrm{C}\right)$ by using the formula:

$$
\text { Temp. }{ }^{\circ} \mathrm{C}=\left(\text { temp. }{ }^{\circ} \mathrm{F}-32\right) / 1.8
$$

Sea level: In this report "sea level" refers to the National Geodetic Vertical Datum of 1929 (NGVD of 1929)--a geodetic datum derived from a general adjustment of the first-order level nets of both the United States and Canada, formerly called Mean Sea Level of 1929.

Trade name: Use of the trade name in this report is for identification purposes only and does not constitute endorsement by the U.S. Geological Survey.

Water year: In this report "water year" refers to the period October 1 through September 30 . 


\title{
Preliminary Evaluation of the Hydrogeologic System in Owens Valley, California
}

\author{
By Wesley R. Danskin
}

\begin{abstract}
Owens Valley is a major source of water for southern California and presently (1986) provides more than 60 percent of the supply for Los Angeles. Since 1970, ground-water withdrawal from Owens Valley has increased, and a decline in the health of vegetation has been reported. In 1982, a cooperative project to study the hydrogeology and plant ecology of Owens Valley was begun by Inyo County, the Los Angeles Department of Water and Power, and the U.S. Geological Survey. As part of this project, the available data and present hydrologic concepts of Owens Valley were evaluated by using a ground-waterflow model. Results of this preliminary evaluation are being used to guide data collection and the development of more sophisticated hydrologic models.

Vast amounts of geologic and hydrologic data have been collected since the early 1900's; however, many parts of the hydrogeologic system have not been defined with sufficient detail to answer present water-management questions. Concepts of local ground-water-flow systems, which are a critical part of water management, are not as well understood as the valleywide flow system. Also, the location and extent of less permeable materials that impede the vertical movement of water are poorly documented. The likely range of aquifer characteristics, except vertical hydraulic conductivity, is well known, but additional work is required to define the spatial distribution of these characteristics.

A set of consistent water budgets is needed, including a surface-water budget, a ground-water budget, and a budget for the entire valley. Ideally, the same items would appear in each budget to assure consistency and faci1itate comparisons with numerical models of either the surface- or ground-water system. The largest component of previous water budgets (evapotranspiration) is largely unverified. Prior estimates of evapotranspiration were based on observed data for grasses and open water; however, there has been no comparison of these estimates with actual field measurements of evapotranspiration for phreatophytic shrubs, the dominant vegetation. Precipitation rates are well documented, but infiltration rates of precipitation on the alluvial fans are virtually unknown. More definitive estimates of local gains and losses for the Owens River are needed to aid in understanding local ground-water-flow systems. Ground-water pumpage from individual wells is measured; however, the quantity of water withdrawn from different zones of permeable material, for example from either side of a confining clay layer, has not been investigated.
\end{abstract}


Simulations of the ground-water system indicate that hydraulic heads are most affected by recharge and discharge in areas near the toes of alluvial fans and along the edge of permeable volcanic deposits. Because these areas are critical in water-management decisions, future data collection and model investigations need to strive to improve hydrologic understanding of these areas and methods of simulating the ground-water-flow system. The two-layer conceptualization of the ground-water system used in the preliminary model produced satisfactory results in most areas of the valley. Ground water flowing in aquifer materials located more than 1,000 feet below land surface did not have a significant effect on hydraulic heads elsewhere in the system. Extensive faulting in the valley produced only localized effects on hydraulic heads. Tungsten Hills, Poverty Hills, and Alabama Hills were found to act as virtually impermeable barriers to ground-water flow, and as such can be excluded from future modeling efforts. In contrast, the importance of inflow through or under the Volcanic Tableland north of Bishop is unknown. Accurate simulation of the ground-water system between Bishop and Lone Pine appears to be possible without simulating the ground-water system in Round Valley or near Owens Lake. Sensitivity analysis for each model parameter indicates that the simulation of steady-state conditions is most sensitive to uncertainty in evapotranspiration rates. In order to accurately simulate the effects of different water-management strategies, an improved quantification of evapotranspiration is needed. Efficient simulation of the ground-water system for water management may require the use of both a general valleywide model and smaller, more detailed area models.

\section{INTRODUCTION}

Owens Valley is a major source of water for southern California and presently (1986) provides more than 60 percent of the supply for the city of Los Angeles (fig. 1). Precipitation in the Sierra Nevada and Inyo and White Mountains, which surround the valley, results in an abundance of water flowing into this high desert basin. Because the valley has no surface-water outlet, streams historically have flowed into Owens Lake, a large saline body of water at the southern end of the valley, and evaporated.

In 1913, the Los Angeles Department of Water and Power constructed a 233-mile-long aqueduct to divert surface water from the Owens River to Los Angeles. This supply was later increased to an average export of 330,000 acre-ft/yr by adding diversions of surface water from Mono Basin, which adjoins the northwestern side of Owens Valley (fig. 1).

In 1970, a second aqueduct to Los Angeles was completed, increasing the total maximum capacity to $565,000 \mathrm{acre}-\mathrm{ft} / \mathrm{yr}$. The average export increased to 482,000 acre-ft/yr. This additional supply was obtained by increasing surface-water diversions from Owens Valley and Mono Basin and by pumping ground water from Owens Valley. Since 1970, the demand for water by Los Angeles has increased. 
Residents of the valley and local businesses that depend on tourism became concerned that the additional export of water by Los Angeles Department of Water and Power was a cause of degradation observed in the Owens Valley environment. Water levels in many wells declined between 1970 and 1978. Vegetation at several locations in the valley showed signs of stress. In some areas, the number of plants was significantly reduced.

In addressing the concerns about water, officials of Inyo County filed a 1 awsuit that required Los Angeles Department of Water and Power to prepare an Environmental Impact Report on increased ground-water pumping. A sequence of litigation ensued and is still pending (1988). The political impasse became more critical because of an impending reduction in one of the alternative sources of water available to Los Angeles. Prior to 1985, Los Angeles, as a member of the Metropolitan Water District of Southern California, was entitled to part of the flow of the Colorado River. This entitlement, which under a judicial mandate was transferred to Arizona, had provided more than 25 percent of the city's water during drought years. As the physical capability of the Central Arizona Water Project increases and more water is taken from the Colorado River, Los Angeles will be forced to rely more heavily on water imported from Owens Valley and northern California. This combination of increasing demand and unresolved litigation emphasizes the need to understand the water resources of Owens valley.

In 1982, the U.S. Geological Survey entered into a cooperative study with Los Angeles Department of Water and Power and Inyo County to evaluate the hydrology of Owens Valley and to provide information that would enable Los Angeles and Inyo County to develop a joint ground-water-management plan for the valley and to assist Los Angeles Department of Water and Power in preparing the required Environmental Impact Report. This 5-year study provides for extensive field investigations in order to (1) determine the evapotranspiration rates of the principal native plant species, (2) determine the effect of water-level fluctuations on the growth and rooting capability of these species, and (3) provide more definitive information about the hydrogeology of Owens Valley. Synthesis of these data will culminate in the development of hydrologic management tools, including a valleywide, hydrologic-optimization model. The part of the overall study presented in this report is a preliminary evaluation of the geologic boundary conditions and aquifer characteristics of the hydrogeologic system in Owens Valley.

\section{Purpose and Scope}

This report has three primary purposes. The first is to evaluate the present (1986) understanding and concepts of the hydrogeologic system. The second is to identify the most important data deficiencies that limit an improved understanding of the hydrogeologic system. The third is to select the most effective mathematical modeling techniques for use in future hydrologic management models. 


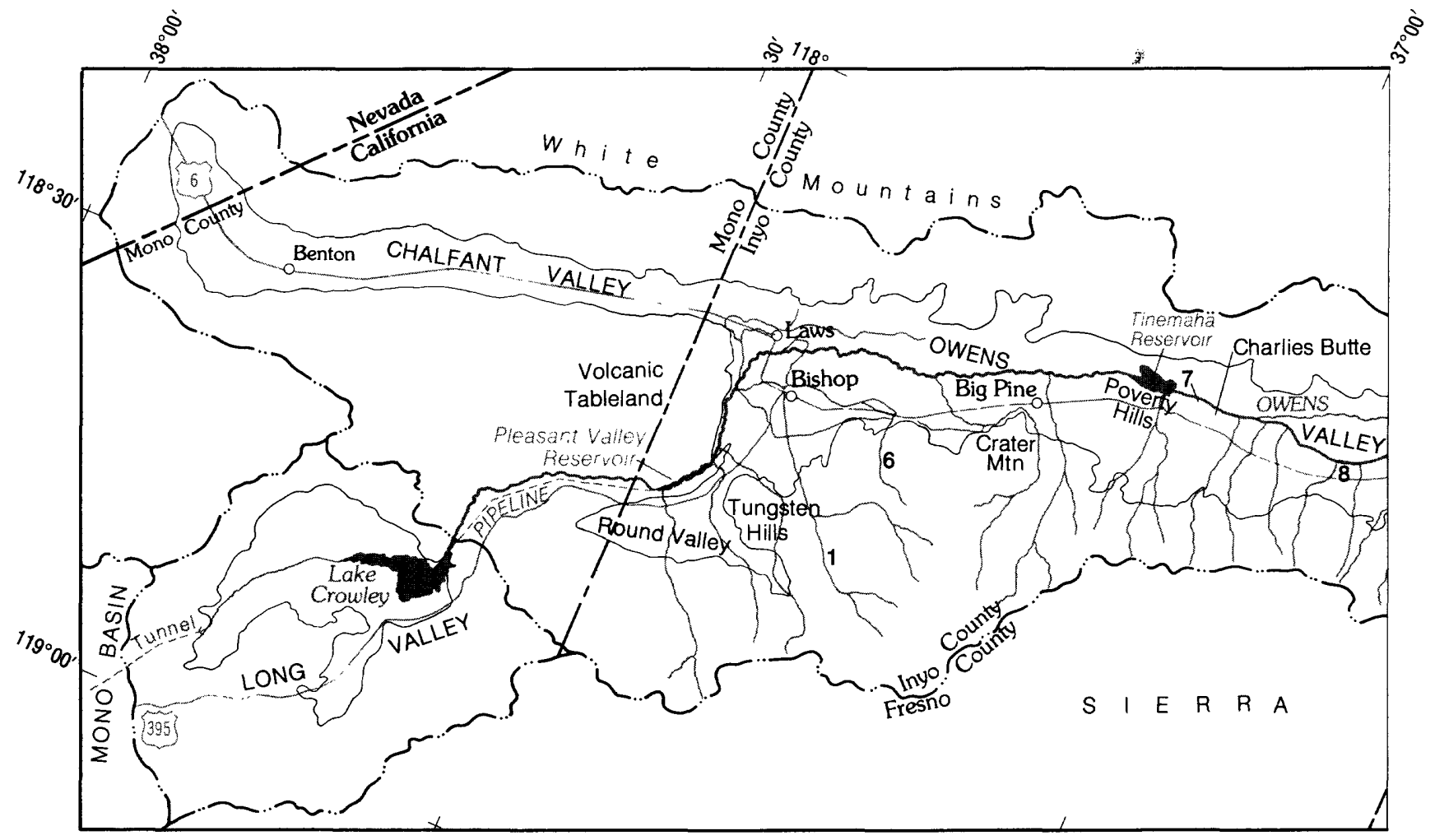

FIGURE 1. - Location of study area.

This preliminary analysis evaluated all available information about the ground-water system, but did not specifically include data that were being gathered concurrently as part of the cooperative study involving Inyo County, Los Angeles Department of Water and Power, and the U.S. Geological Survey. By use of the available information, a mathematical model was developed to simulate ground-water flow through the saturated alluvial and volcanic deposits in Owens Valley. The period of water years 1935-70 was selected as a time when the ground-water-flow system was approximately in equilibrium and was used as a steady-state condition for calibrating the ground-water-flow model. Transient and predictive simulations were not a part of this particular investigation, but will be included in a later phase of the overall cooperative study. The preliminary ground-water-flow model was used to find any inconsistencies between available data and present hydrogeologic concepts. In addition, areas of the valley with sparse data or poorly defined concepts were identified in order to determine how critical these areas are to simulation of ground-water movement, and what additional data would be most useful. Insight gained in developing the preliminary model will be used in the design of more sophisticated hydrologic models for future management of water resources in Owens Valley. 


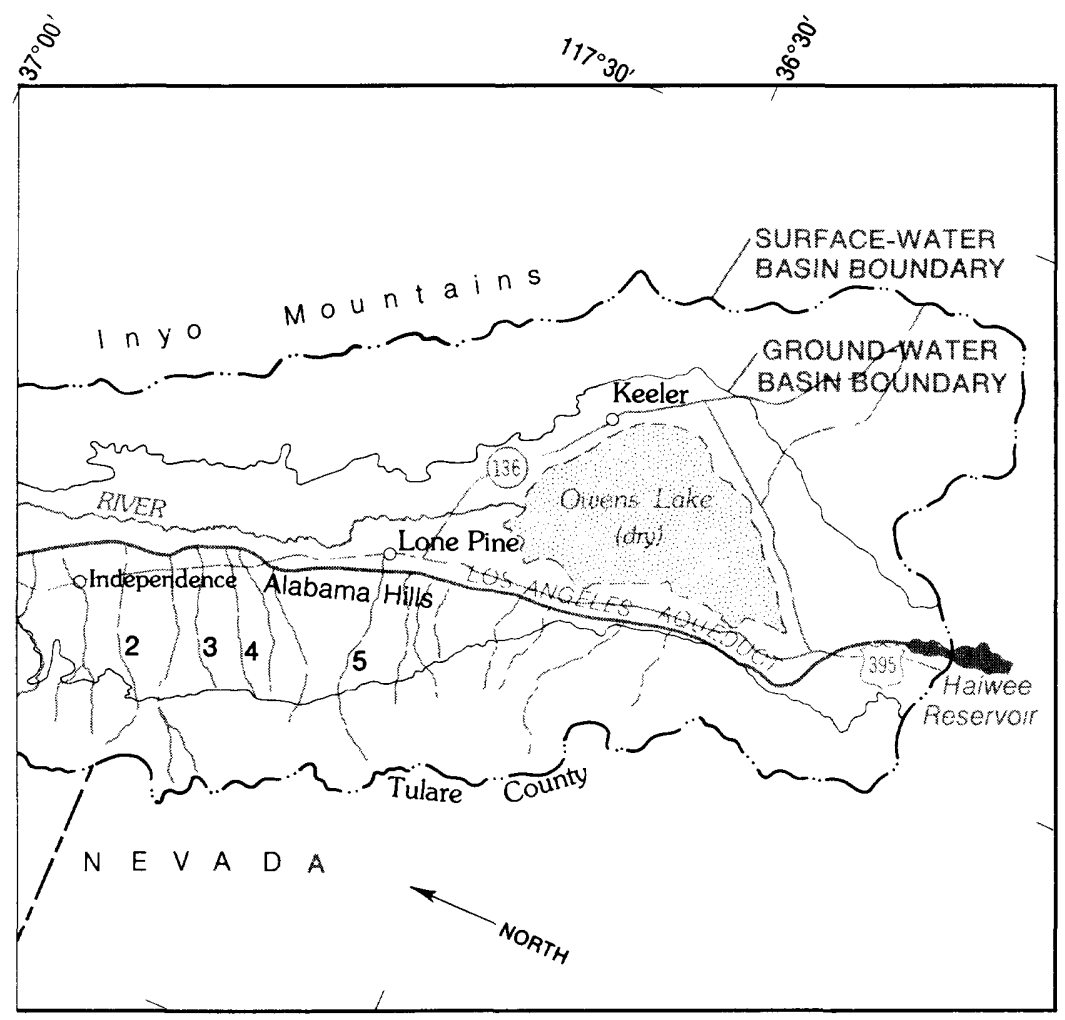

\section{EXPLANATION}

\section{STREAMS AND SPRINGS}

1 Bishop Creek

2 Symmes Creek

3 Bairs Creek

4 George Creek

5 Lone Pine Creek

6 Keough Hot Springs

7 Seeley Springs

8 Blackrock Springs

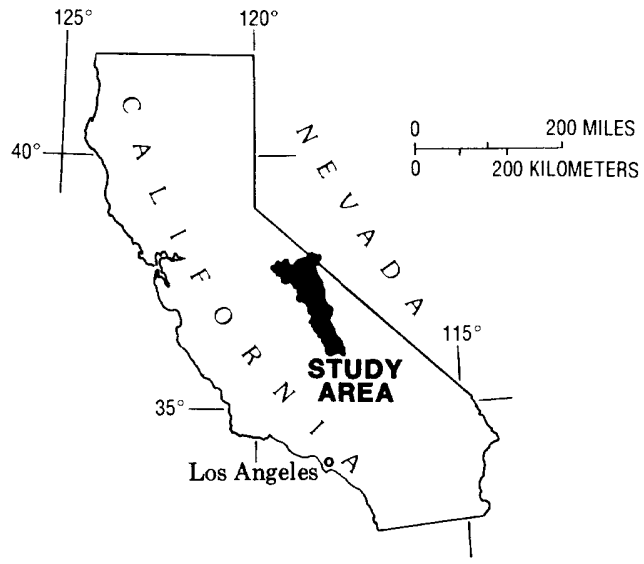

\section{Physiographic Setting}

Owens Valley is both a major recreational area and the principal source of water for Los Angeles. Located on the eastern slope of the Sierra Nevada, the drainage area includes approximately 3,300 $\mathrm{mi}^{2}$ (fig. 1). Although the valley floor is relatively flat, sides of the valley rise steeply from an altitude of 3,600 feet above sea level at Owens Lake to more than 14,000 feet in the Sierra Nevada. This great topographic relief gives the area a variety of climatic zones and is a major attraction for tourists who come to hunt, fish, camp, and enjoy the many outdoor sports. Temperatures in Owens Valley are extreme, ranging from less than $0{ }^{\circ} \mathrm{F}$ in winter to more than $100{ }^{\circ} \mathrm{F}$ in summer. Precipitation occurs as both rain and snow and comes predominantly from moisture-laden air moving across the valley from west to east. As a result, most of the annual precipitation is estimated to fall on the western side of the valley. The resident population of the valley is concentrated in four major towns--Bishop, Big Pine, Independence, and Lone Pine (fig. 1). 


\section{Relation to Other Investigations}

The geology and hydrology of Owens Valley have been studied frequently since the early 1900's. Because of the extensive faulting, glaciation, and volcanism that have occurred in Owens Valley, the geologic history in particular has been a subject of continuing interest and debate. Numerous publications prior to 1900 examined the general geologic structure of the valley and proposed a geologic history for the major features. Knopf and Kirk (Knopf, 1918) summarized previous studies and mapped the major stratigraphic units. Pakiser and others (1964) used geophysical techniques to further define the major structural characteristics and compiled several cross sections showing depth to crystalline bedrock. Bateman (1965) concentrated on the geologic structure of the Bishop area by using seismic and gravity profiles. In addition, many smaller, site-specific studies have been conducted by individual researchers, primarily from universities. As a result of the numerous studies, geologic quadrangle maps are available for nearly all parts of the valley.

Hydrologic investigations have paralleled geologic studies since the early 1900's primarily because of the abundance of water in an otherwise arid region. W.T. Lee (1906) and C.H. Lee (1912) did preliminary hydrologic investigations and documented conditions in Owens valley prior to the diversion of surface water to Los Angeles, which began in 1913. Conkling (1921) summarized the availability and use of water in Mono Basin and Owens Valley in order to evaluate the potential export of water from Mono Basin to Owens Valley. As demand for water in Los Angeles increased, Los Angeles Department of Water and Power collected vast amounts of data on streamflow and ground-water pumpage throughout much of the valley. Although most of these data have not been published, four summaries are available including three versions of an Environmental Impact Report (Los Angeles Department of Water and Power, 1972, 1976, 1978, 1979). The California Department of Water Resources (1960) calculated the quantity of water in the valley that could be used for various recreational projects. D.E. Williams (1969) investigated methods for increasing ground-water storage and developed a mathematical ground-water-flow model for a part of the southern half of Owens Valley.

More recently, P.B. Williams (1978) used a regression model to analyze the relation between water-level declines, precipitation, and ground-water pumping. Hardt (1980) defined unresolved hydrologic questions and summarized current understanding of the multiple-layer, ground-water system in the valley. Griepentrog and Groeneveld (1981) summarized hydrology of the valley and impacts of recent water-level declines on vegetation. Yen (1985) developed a two-layer, ground-water-flow model of the southern half of the valley to test methods for including probability in simulations of the ground-water system. Investigations of water quality have been included as sections in larger reports, but have not been as prominent as studies of water quantity. This lack of attention probably results from the uniformly high quality of both surface and ground water. 
The cooperative study by Inyo County, Los Angeles Department of Water and Power, and the U.S. Geological Survey is designed to integrate prior hydrologic knowledge of the valley with a detailed, data-intensive analysis of the interaction between vegetation and the hydrogeologic system. The cooperative study is composed of several separate investigations including:

- Preliminary evaluation of the hydrogeologic system using a valleywide, ground-water-flow model (this report).

- Geological and geophysical surveys to determine the structure of the valley and composition of unconsolidated deposits and how these affect ground-water flow.

- Drilling test holes throughout the valley.

- Site evaluations of hydraulic properties of the ground-water system.

- Measurements of plant stress as related to depth to water.

- Mapping of the species and percentage of vegetative cover throughout the valley.

- Measurements of evapotranspiration at seven representative sites using an energy budget.

- Development of an unsaturated-saturated, one-dimensiona1, evapotranspiration model.

- Development and testing of an efficient procedure to assess the reliability of a ground-water model.

- Development of a hydrologic-optimization model that incorporates these findings and that can be used for management of water resources throughout the valley.

\section{Methods of Investigation}

This preliminary evaluation of the hydrogeologic system of Owens Valley consists of a review of published geologic and hydrologic information, a summary of available water-budget data, and the testing of hydrologic concepts of the ground-water system by use of a distributed-parameter, ground-waterflow model.

Previous hydrologic investigations in Owens Valley generally have been of two types. The first type includes localized studies, such as aquifer tests, designed to investigate the hydrologic characteristics of a relatively smal1 part of the valley. These site studies provide necessary local information, but results from different studies may not be hydrologically compatible. The second type includes valleywide studies used to assess the average hydrologic characteristics for the entire valley. Although valleywide studies may give insight into the overail effects of management decisions, they are unable to determine local effects. For example, a balanced valleywide water budget does not assure that specific areas in the valley are budgeted correctly. Furthermore, a valleywide water budget may not be compatible with the hydraulic properties of the ground-water system determined by localized studies. 
To help overcome these deficiencies, a distributed-parameter, ground-water-flow model was developed for the entire Owens Valley. This type of model integrates local data, such as results from an aquifer test, with valleywide data, such as a water budget. Perhaps most important, the model assures that local values of the water budget and local hydraulic properties of the ground-water system are compatible. In addition, minor modifications in the model can be used to evaluate different hydrologic concepts of the ground-water system.

Many different numerical modeling techniques could be used to simulate the ground-water system. One purpose of this preliminary investigation was to evaluate the different methods of simulating the ground-water system so that the most appropriate method could be determined for use later in the cooperative study. The particular model documented in this report is a two-layer, finite-difference model using the formulation of McDonald and Harbaugh (1984). During the evaluation process, other types of ground-water models were developed and tested for parts of Owens Valley. Although these additional modeling exercises are not fully documented in this report, significant findings from them are summarized in a later section entitled, "Findings from Other Ground-water Modeling Studies in Owens Valley."

The final part of this evaluation included a sensitivity analysis of the valleywide ground-water model. Any complicated model, particularly a numerical one, requires that many components of the model be estimated. A sensitivity analysis is one way to determine the importance of each of the components and what effect an error in one of them would have on the results of the model. The procedure requires changing selected components a small amount and noting the change in the results. The greatest change in results is produced by the most sensitive components. In this way those parts of the model that exert the most control on the ground-water system can be identified for additional data collection and analysis.

\section{Acknowledgments}

The Los Angeles Department of Water and Power and the Inyo County Water Department provided much of the data necessary for this study. Important explanations of the data and valuable insights about the hydrology of the valley were gained from discussions with several colleagues in each of these departments, including Melvin L. Blevins, Eugene L. Coufal, Thomas E. Griepentrog, David P. Groeneveld, William R. Hutchison, Gregory L. James, and Russell H. Rawson. Helpful suggestions also were provided by Gary L. Guymon and Chung-Cheng Yen of the University of California at Irvine. 


\section{Geologic Setting and History}

Owens Valley is a deep alluvial basin bounded by steep mountain ranges and is tectonically similar to other valleys in the Basin and Range Province, which is described by Fenneman (1931). Figure 2 is a generalized map showing the surficial geology of Owens Valley and the surrounding areas. Figure 3 is a typical geologic section from west to east across the valley and shows the major geologic structure and erosional deposits. Formation of the valley began during crustal extension when a structural block dropped down between vertical faults separating it from the Sierra Nevada on the west and from the White and Inyo Mountains on the east (Pakiser and others, 1964). Erosion along the valley sides has progressively widened the valley and filled the deepening trough with alluvial deposits. Because of the substantial uplift, large alluvial fans developed, particularly along the western side of the valley. Major streams traversing the middle of the valley have reworked material from the fans and redeposited it as moderately well-sorted layers of silt, sand, and gravel. Intermittent blockages of surface-water outflow from the valley have caused the formation of large lakes and the deposition of layers of clay and silt over much of the valley. Volcanic vents and fissures occasionally extruded lava and pyroclastic debris. Although most of this volcanic material now lies buried within the alluvial deposits, some material remains exposed at the land surface. During the ice ages, glaciers flowed from the Sierra Nevada into Owens Valley and formed extensive moraines.

Owens Valley is not, however, a simple tectonic trough. The main part of Owens Valley has undergone other complex faulting and shows evidence of rotation and structural warping. As a result, the thickness of alluvial deposits ranges from about 4,000 feet near Bishop and less than 3,000 feet near Tinemaha Reservoir to more than 8,000 feet beneath Owens Lake (fig. 1). Along the eastern side of the valley, alluvial fans are small and the Inyo and White Mountains rise abruptly from the valley floor. Pakiser and others (1964) suggested that this physiographic evidence indicates that most of the vertical movement has occurred close to the edge of the basin. In contrast, along the western side of the valley, large alluvial fans have developed and the Sierra Nevada rise from the edge of the basin in a series of steps. Knopf (1918) stated that this pattern indicates that the valley floor has subsided along a series of parallel, en echelon faults. This en echelon movement in combination with possible warping and rotation of smaller blocks has produced alluvial deposits that vary in composition and thickness, especially beneath the western side of the valley. As a result, accurate determination of the depth of alluvial deposits is complicated and is not yet complete. 


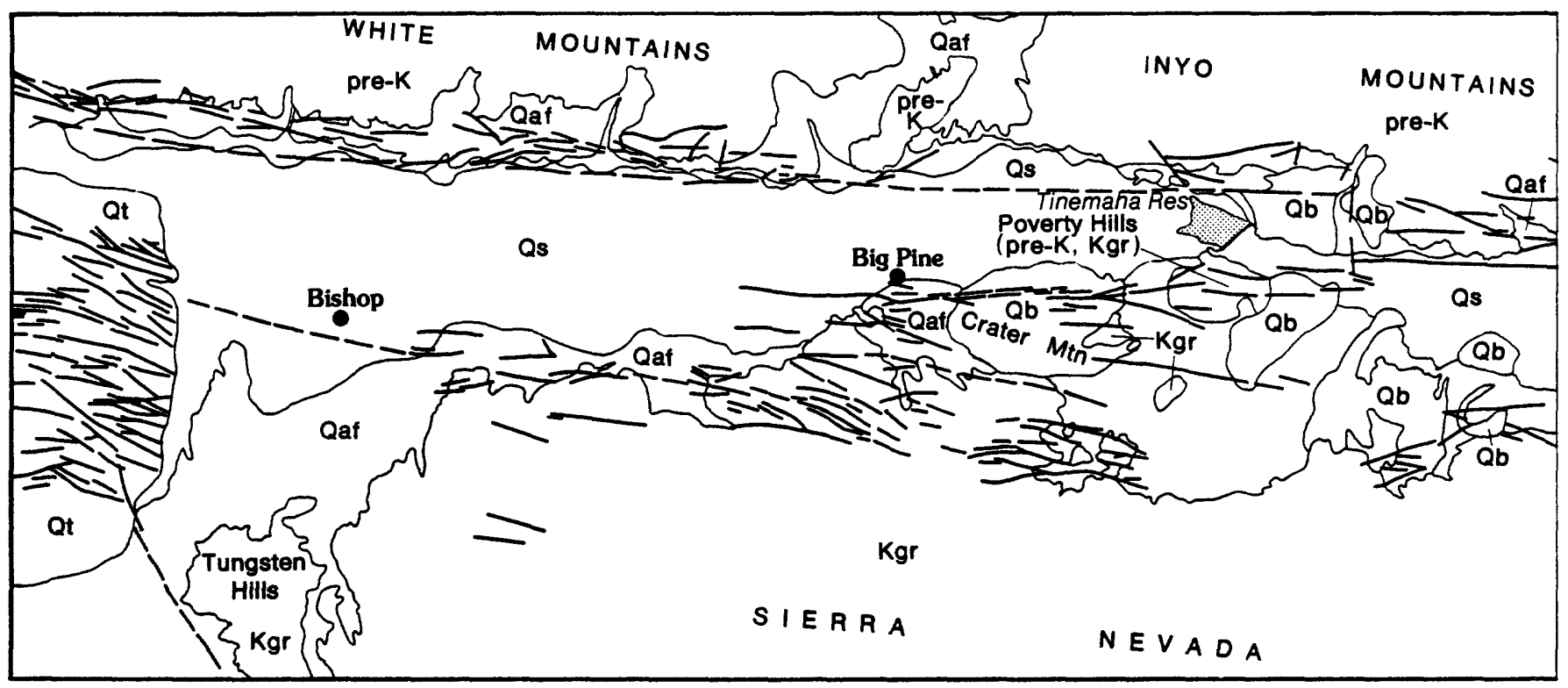

EXPLANATION

ALLUVIAL DEPOSITS

Qaf Alluvial fan deposits
\begin{tabular}{|l} 
Qs \\
Stream-channel and deltaic \\
deposits
\end{tabular}
QIb Lakebed deposits

VOLCANIC DEPOSTIS

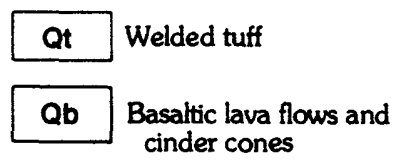

GRANITIC AND METAMORPHIC ROCKS

Kgr Granitic rocks

pre-K Metamorphic rocks

- FAULT - Dashed where approximate CONTACT

A-A' LINE OF SECTION (fig. 3)

FIGURE 2. - Surficial geology of Owens Valley (adapted from D.E. Williams, 1969).

In addition to the major structural faults, numerous minor faults or fractures are evident in both alluvial and volcanic deposits throughout the valley. Representative of these features are a sequence of offsets found in an alluvial fan just north of the Alabama Hills and a series of fractures crossing Crater Mountain south of Big Pine. In most areas the depth, inclination, and amount of offset of the fractures is not known. However, recurring earthquakes indicate that deformation and seismic activity are continuing. One of the most notable earthquakes, which occurred in 1872 , caused as much as 20 feet of offset along a scarp running half the length of the valley.

Varying levels of volcanic activity have also played an important role in the geologic history of Owens Valley. Following the major structural 

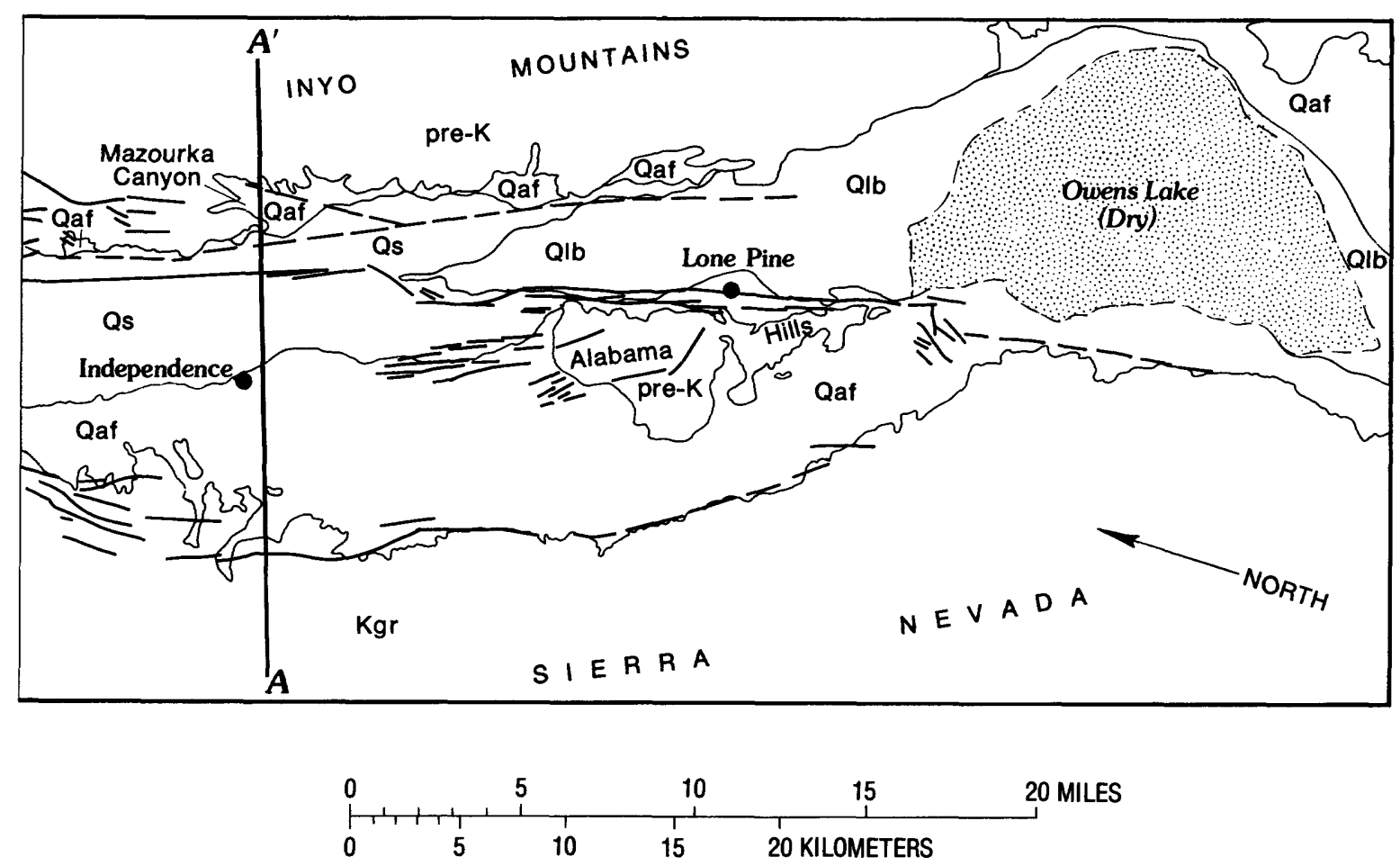

movements that shaped the valley, the volcanic plateau that lies to the north of Bishop was formed by the forceful extrusion of pyroclastic material. The resulting welded tuff is approximately 400 to 500 feet thick and overlies a buried stream channel of undetermined thickness (Gilbert, 1938, as cited by Pakiser and others, 1964, p. 13). More recent volcanic eruptions are exposed as cinder cones and lava flows near Big Pine. Most researchers believe that these volcanic features are the surficial expressions of thin sill deposits, generally not more than 200 to 300 feet thick. However, the subsurface extent of these features, as well as others that may be present, is largely unknown.

A much more extensive discussion of the geology of Owens Valley and the surrounding area can be found in reports by Bateman (1965) and Pakiser and others (1964). 


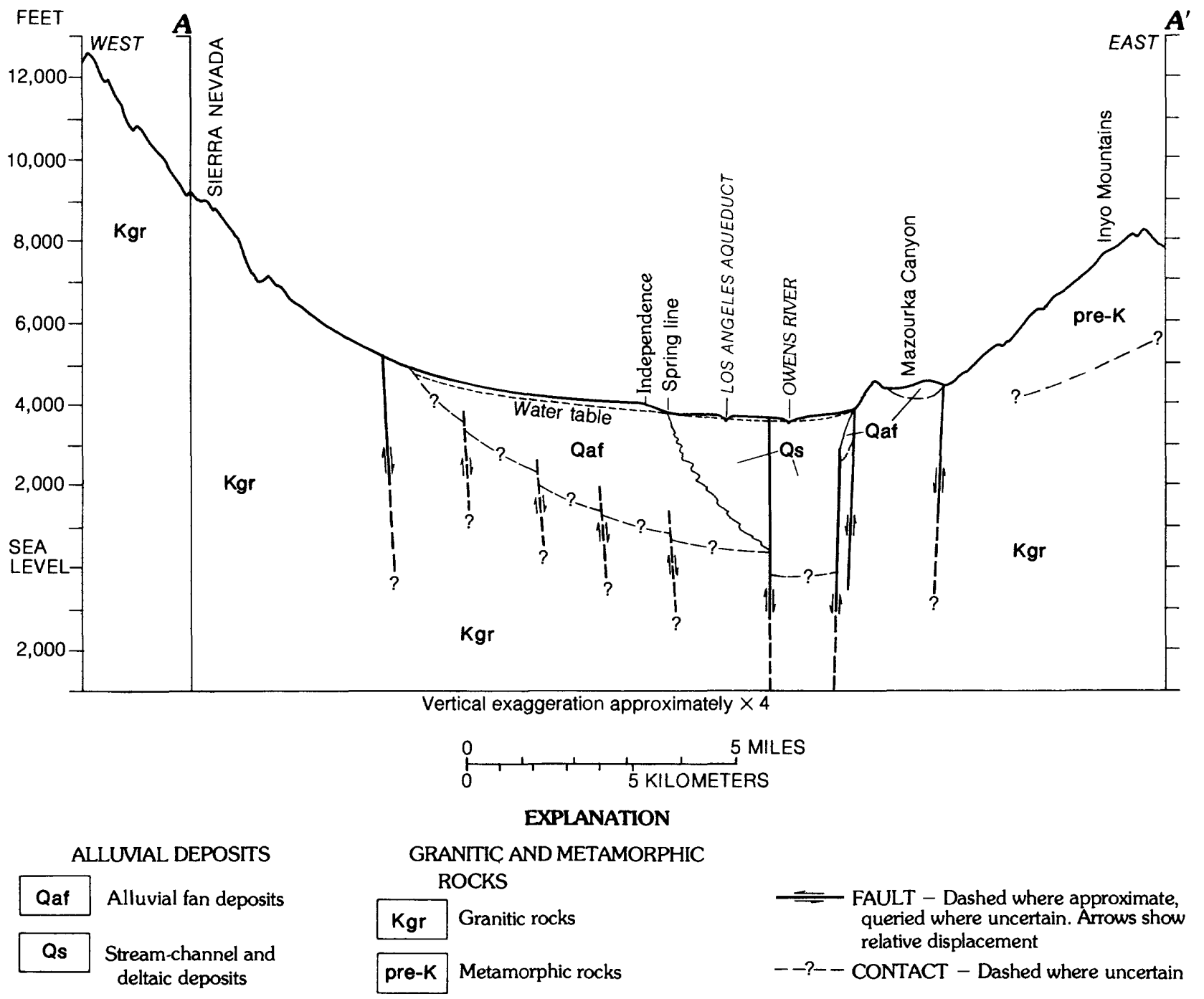

FIGURE 3. - Typical geologic section of Owens Valley. (Location shown in figure 2) 
Geologic Units and Their Water-Bearing Characteristics

\author{
Granitic and Metamorphic Rocks
}

Granitic rocks underlie Owens Valley and form the core of the mountains that surround the valley. A mantle of metamorphic rock covers the granitic rock in some areas but has been removed by erosion elsewhere. As shown in figure 2, the eastern side of the valley has undergone less erosion and exhibits more of the remaining mantle of metamorphic rocks.

Bedrock is exposed in the alluvial basin at three locations: Tungsten Hills near Bishop, Poverty Hills near Tinemaha Reservoir, and Alabama Hills west of Lone Pine (fig. 2). The Tungsten Hills are composed of granitic rocks, and although they are faulted and dissected by streams, few springs have been observed. Because there is no evidence that the hills hold or transmit significant quantities of water, it appears that they form an effective barrier to ground-water flow.

The Poverty Hills are located in an area of complex geology and regional structural movement. Geophysical evidence suggests that the hills consist of a core of granitic rock overlain by a thin veneer of metasedimentary rock (K.J. Hollett, U.S. Geological Survey, oral commun., 1985). Although several springs are found at the base of nearby volcanic deposits, the Poverty Hills seem to be relatively impermeable to ground-water flow. Previous hydrologic investigations have assumed that the hills restrict the flow of ground water down the valley to a narrow trough of alluvial deposits underlying Tinemaha Reservoir.

The Alabama Hills are structurally similar to the Poverty Hills and also appear to restrict the movement of ground water. The Alabama Hills are composed mostly of granitic rocks, although a mantle of metavolcanic rocks partially covers the east side. The scarp of the 1872 earthquake and geophysical studies by Pakiser and others (1964) indicate that a major fault forms a boundary between the east side of the Alabama Hills and the main part of the valley. In addition, several en echelon fractures are evident in alluvial fans north of the Alabama Hills. The extent of the fractures is not known; however, seepage of water along the fractures supports much more vegetation than normally is found on alluvial fans. Lone Pine Creek bisects the hills and has created a small alluvial channel. Four other, smaller creeks cross the south part of the hills in narrow incised channels.

Vegetation on each of the bedrock outcrops in Owens Valley is sparse and probably subsists on precipitation. An exception to this sparseness is the west side of the Alabama Hills, where the presence of a meadow indicates that a ponding of ground water occurs. 


\section{Volcanic Deposits}

The largest volcanic deposit in the Owens Valley area comprises the volcanic plateau north of Bishop. This massive formation, locally referred to as the Tablelands, is estimated to be more than 400 feet thick and is composed of many individual layers of welded volcanic material. Because of partial melting and compaction of the material during its deposition, water is not readily transmitted through the layers. However, thin erosional deposits and cooling cracks between layers may conduct some water. These conduits probably result in minor outflow from the Tablelands, such as the springs along the Owens River noted by C.H. Lee (1912). Aerial photos reveal numerous fractures in the top of the plateau, but their vertical extent and ability to transmit water is not known.

Smaller volcanic deposits on either side of Tinemaha Reservoir are near-surface expressions of recent volcanic activity that is even more evident north of Bishop in Long Valley and Mono Basin. The deposits appear as volcanic cinder cones as much as 1,000 feet high and volcanic flows of broken lava. The flows have a shape similar to that of nearby alluvial fans, extending from the edge of the valley almost to its center. Although the surficial expression of the volcanic deposits is obvious, the subsurface extent can only be approximated. Most researchers believe that the volcanic deposits are relatively shallow and are underlain by alluvial material (Pakiser and others, 1964; W.T. Lee, 1906; D.E. Williams, 1969). It seems likely that other, unexposed, undetected volcanic deposits may be present, particularly near Tinemaha Reservoir. However, a more complete understanding of the volcanic area has been limited because nearly all drilling has been shallow and close to the volcanic outcrops. Additional buried volcanic deposits present at different locations and depths probably would affect ground-water flow through the area and make hydrogeologic interpretations more difficult.

The volcanic deposits near Tinemaha Reservoir are extremely effective in transmitting large quantities of water. Most of the high production wells in Owens Valley are located in the volcanic deposits, and records indicate that several of these wells are capable of continuously producing more than 4,500 $\mathrm{gal} / \mathrm{min}$ (gallons per minute). Some wells can consistently produce more than $9,000 \mathrm{gal} / \mathrm{min}$ with less than 100 feet of drawdown. This capacity is maintained in part by the abundant, nearby surface-water inflow that averages more than 43,000 acre-ft/yr. Not surprisingly, springs are common along the interface where the volcanic flows meet the alluvial deposits near the center of the valley. These springs probably are caused by a combination of factors. First, a significant decrease in the ability to transmit water occurs between the permeable volcanic material and the less permeable silt and clay. This decrease forces ground water to rise, in this case to the land surface. Second, faulting within either the volcanic or alluvial deposits can cause a similar obstruction to horizontal ground-water flow and result in an upward seepage of water. The layered structure of volcanic deposits usually allows water to move horizontally much more easily than vertically. However, the presence of numerous faults or fractures, acting as vertical conduits of water between the layers, can markediy improve the vertical permeability of volcanic deposits. This potential effect on the ground-water-flow system near Tinemaha Reservoir is recognized, but has not been documented. 
Vegetation on the volcanic deposits is sparse compared to that on alluvial deposits. This difference results from a combination of poorly developed soil horizons and depths to ground water of more than 20 feet. Annual species of grasses predominate on the volcanic deposits, except along the stream channels where phreatophytic shrubs are plentiful.

\section{Alluvial Deposits}

The total thickness of the alluvial deposits ranges from a few hundred feet beneath the upper part of the alluvial fans to between 3,000 and 8,000 feet in the center of the valley. To the north, the alluvial deposits extend past Bishop and under the Volcanic Tablelands to what Pakiser and others (1964) described as a bedrock barrier separating Owens Valley from Long Valley. The alluvial deposits also extend northwest into Round Valley and northeast into Chalfant Valley reaching almost to the Nevada State line. The southern boundary of alluvial deposits is formed by the Coso Range in the southeast and by a ridge of granitic rock extending beneath Haiwee Reservoir. The thickness of alluvial deposits above the ridge is not known.

As part of this preliminary analysis of the Owens Valley ground-water system, the alluvial deposits were divided into three major categories on the basis of how they were deposited and their water-bearing characteristics: (1)

alluvial fan deposits, (2) stream-channel and deltaic deposits, and (3) lakebed deposits.

\section{Alluvial fan deposits}

Alluvial fan deposits are present primarily along the western side of the valley. Although some fans are found on the eastern side, they are generally much smaller, probably because less precipitation falls on the eastern side of the valley. This absence of alluvial fan formation has caused an abrupt transition from the eastern edge of the valley floor to the Inyo and White Mountains.

In contrast, large alluvial fans have been formed on the western side of the valley by more than 30 major streams emerging from the Sierra Nevada. Most of the fans begin at about 6,000 feet in altitude, slope downward at a grade of about $300 \mathrm{ft} / \mathrm{mi}$, coalesce, and end as much as 2,000 feet 1 ower on the valley floor. Total thickness of the western fans is not known, but estimates range from a few feet at the heads of the fans to more than 1,000 feet at the toes. Incised stream channels in the fans indicate that major formation of the fans probably occurred during periods of significantly greater streamflow and when there was abundant erosional material, probably during or immediately after glaciation. Logs of wells drilled on the fans show that the fans are composed of poorly sorted material, ranging in size from clay to boulders more than 6 feet in diameter. Virtually no clay layers are found in the upper 500 feet of the fan deposits except near the toes of the fans. 
An area with numerous fractures north of the Alabama Hills has an abundance of springs and appears to be hydrogeologically different from other alluvial fan deposits. These fractures may be surficial expressions of the extensive faulting that probably has occurred beneath all the alluvial fans during uplift of the Sierra Nevada. Individual traces of faults or fractures also appear on the land surface in other areas of the valley, particularly near the toes of alluvial fans. However, the hydrogeologic significance of individual faults or fractures varies considerably. Numerous minor fractures that are noticeable on aerial photos do not appear to affect the ground-water-flow system. Other fractures or faults do impede ground-water flow and can be inferred from the presence of springs or the analysis of aquifer tests. This barrier effect results from two causes. First, in some faults, gouge is created during the crushing movement of the earth. Fault gouge is very fine, clay-size material that can retard the flow of water. Second, the fault may offset sand and gravel lenses thereby impeding the effective transmission of water from one side of the fault to the other.

Vegetation on the alluvial fans consists primarily of grasses and sagebrush with some trees near the mountains. Riparian plants, such as willows, grow along the stream channels, but the great depth to water in all other areas of the fans prohibits their growth. Although the alluvial fan deposits are not used for substantial ground-water production, they do play an important role in recharging the valleywide ground-water system.

\section{Stream-channel and deltaic deposits}

Alluvial deposits in the middle of the valley consist primarily of stream-channel deposits including reworked material from the alluvial fans, floodplain and deltaic deposits formed by the Owens River, and lakebed deposits. During geologic formation of the valley, the ancient Owens Lake repeatedly changed in size. As a result, the Owens River emptied into the lake at different locations up and down the valley. At the juncture between the ancient river and the lake, deltaic deposits were formed by the faster-moving river water entering the still lake water. Upstream of the juncture, cut-and-fill and floodplain deposits typical of a river system were formed. Beneath the center of the lake, deposits containing a high percentage of clay were formed. As the size of the lake fluctuated, the position of the deltaic deposits moved up and down the valley. Some investigators have estimated that the northern limit of the lake may have extended almost to the Poverty Hills (C.H. Lee, 1912). There is also some evidence that a second lake was formed near the present location of Tinemaha Reservoir (K.J. Hollett, U.S. Geological Survey, oral commun., 1985). This lake would have extended north towards the area where Bishop is today and created a depositional environment similar to that of the ancient Owens Lake.

As the Owens Valley was being filled with erosional material, the Owens River meandered from one side of the valley to the other, reworking both the coarse alluvial fan deposits and finer deltaic deposits. This reworking 
resulted in stream-channel deposits with coarser material close to the alluvial fans and progressively finer material toward the middle of the valley. Although the original deposition of deltaic materials may have produced relatively continuous sand and clay layers, subsequent reworking appears to have removed any significant lateral continuity which may have once been present. Analysis of lithologic well logs indicates that distinct clay layers range from 5 to 25 feet in thickness and are continuous for no more than a few hundred feet. However, some logs do suggest that general zones of greater or lesser clay content may occur. These zones might coincide with the location of the ancient Owens Lake during a particular depositional episode.

Faulting in the middle of the valley has further disrupted the horizontal continuity of stream-channel and deltaic deposits. For example, the main scarp of the 1872 earthquake displays more than 20 feet of offset and is visible for almost half the length of the valley. The surficial traces of more than 100 other possible fractures or faults have been mapped by investigators at the University of Nevada at Reno from aerial photographs, but the amounts of subsurface offset have not been determined. In addition, many fractures or faults may exhibit no surficial expression. The degree to which the offset of aquifer material by specific fractures or faults retards the flow of ground water through the valley is largely unknown.

Areas of vegetation covering the middle of the valley have been categorized as predominantly alkali grassland, alkali scrubland, and semiarid scrubland (Los Angeles Department of Water and Power, 1976). Plants in these areas include both grasses and phreatophytes, primarily saltgrass, alkali sacaton, Nevada saltbush, rabbitbrush, greasewood, and shadscale. Along the Owens River upstream of the intake to the aqueduct, riparian vegetation is dominant as tule marshes and woodlands. The relatively small amount of irrigated and urban land in the valley is concentrated near Bishop and Big Pine. Both the density of vegetation and the salinity of the soil appear to be strongly related to the depth of ground water, which in the middle of the valley ranges from less than 1 foot to as much as 15 feet.

\section{Lakebed deposits}

The great thickness of alluvial deposits beneath Owens Lake (nearly 8,000 feet compared to 3,000 to 4,000 feet in other parts of the valley) indicates that much of the time it was the lowest point in the valley and the terminus of the Owens River. During times when the Owens River was prevented or was partially restricted from flowing out of the valley, a lake would form and erosional material would accumulate. The lakebed deposits are similar to the deltaic deposits, but are usually finer grained, consisting mostly of clay and silt. In addition, higher accumulations of salts are usually present because of evaporation from the lake. During some periods, the river was capable of flowing out of the valley to the south. If, under these conditions, the lake were drained, then either erosion of the lakebed deposits would occur or stream-channel material would be deposited. 


\section{Surface Water}

Before diversion of water to Los Angeles, the surface-water system of Owens Valley was controlled by the Owens River and by runoff along the western slopes of the valley. Historically, the Owens River flowed from its headwaters in Long Valley, through a deep gorge in the Volcanic Tableland, into Owens Valley. At fairly even intervals, smaller streams entering from the western side of the valley merged with the Owens River, flowed down the middle of the valley, and emptied into the saline Owens Lake. During recent geologic periods, the valley has had no natural outlet, and all surface water reaching Owens Lake evaporates.

When diversions of surface water began in 1913, structures were built to regulate flow and to bypass Owens Lake. In addition, a tunnel was constructed from Mono Basin into Long Valley, and a pipeline was constructed from Long Valley through the Volcanic Tableland into Pleasant Valley Reservoir north of Bishop (fig. 1). The tunnel allowed Los Angeles Department of Water and Power to augment the natural flow of the Owens River with surface water from Mono Basin. Downstream from Pleasant Valley Reservoir, the Owens River is used to convey water through the northern half of Owens Valley to Tinemaha Reservoir south of Big Pine. This reservoir was constructed primarily to regulate the flow of water to Los Angeles. South of Tinemaha Reservoir, virtually all flow in the Owens River is diverted into the Los Angeles Aqueduct. Any water remaining in the Owens River continues to flow in the natural stream channel, and eventualiy empties onto the mostly dry salt flats of Owens Lake. The Los Angeles Aqueduct follows the lower edge of alluvial fans on the western side of the valley and empties into Haiwee Reservoir at the southern end of the valley.

Streamflow from the Sierra Nevada provides most of the additional surface-water inflow to Owens Valley. Contributions of streamflow from the Inyo and White Mountains have been estimated to be about 10 percent of the total natural inflow (Los Angeles Department of Water and Power, 1972). In the northern half of the valley, most of the streams flowing down the alluvial fans are diverted into canals when they reach the valley floor. Water is distributed for agricultural and domestic uses, and any excess is discharged into the Owens River. In the southern half of the valley, streams flowing down the alluvial fans on the western side are captured when they reach the aqueduct, and flow is diverted to Los Angeles. Although canals and agricultural ditches are present south of Tinemaha Reservoir, they are currently used far less than those near Bishop or Big Pine. In years when runoff is average or below-average, little or no surface water flows east of the aqueduct. 
During years with an abundance of surface water, the same distribution pattern is maintained. However, excess water that cannot be diverted into the aqueduct is spread over the ground surface on the alluvial fans. In this way, some of the excess water may percolate and be stored in the ground-water system. In years of exceptionally high runoff, excess surface water may even be released onto the valley floor into old stream channels and irrigation canals.

\section{Ground Water}

Occurrence and Movement of Ground Water

Ground water is present in the pore spaces of the unconsolidated alluvial deposits and in the clinker and fracture zones of volcanic rocks in Owens valley. The alluvial deposits are bounded on both the eastern and western sides of the valley by dense granitic and metamorphic rocks. These rocks do not contain or transmit significant quantities of water. Volcanic rocks near Big Pine have fractures and void spaces which are connected and which can transmit large quantities of water very rapidly. Volcanic rocks north of Bishop are much denser and less capable of transmitting water. However, springs along the base of the Volcanic Tableland were observed by C.H. Lee (1912) and indicate that some water can be transmitted through or under those volcanic rocks. Beneath the alluvial and volcanic deposits are granitic and metamorphic rocks similar to those found in the mountains on either side of the valley.

The pattern of ground-water flow is controlled to a large degree by the surface-water system. Each of the streams flowing down the alluvial fans loses water. This water percolates vertically, enters one of many sand and gravel lenses, and flows toward the middle of the valley. Natural outflow of ground water is either from local evapotranspiration by plants on the valley floor or from seepage into the Owens River. Some additional water is discharged from the ground-water system by springs and seeps, particularly near the Big Pine volcanic deposits and along the toes of the alluvial fans.

Underflow of ground water into or out of Owens Valley is likely, but has not been well documented. The most probable areas of inflow are from Round Valley, through alluvium beneath the Volcanic Tableland north of Bishop, and from Chalfant Valley. The most probable area of outflow is south of Owens Lake, particularly through the alluvial deposits beneath Haiwee Reservoir. 
The general directions of ground-water flow probably have not been changed either by the diversion of surface water or by the withdrawal of ground water for export to Los Angeles. Ground water is still recharged on the alluvial fans and discharged from the middle of the valley. However, local ground-water-flow patterns and rates have changed, particularly near well fields. Although these local effects are recognized, the scope of this preliminary evaluation is limited to analyzing the general characteristics of the valleywide, ground-water-flow system.

Because alluvial materials in Owens Valley were deposited and reworked into a complicated array of lenses, ground-water flow actually occurs in many different zones. Within alluvial fan deposits most of the lenses are composed of sand and gravel. Thus, ground water in these areas forms a single, unconfined aquifer. Well logs indicate that toward the toes of the fans the number of clay layers increases. As ground water flows in sand and gravel lenses beneath the clay layers, confining pressure is created. This pressure varies depending on the particular lens, but in general increases with depth and distance from the alluvial fan. For example, hydraulic heads more than 30 feet above land surface have been measured in 300-foot wells near the Owens River. In the same location, hydraulic heads for the uppermost, unconfined zone are 1 to 4 feet below land surface. The higher pressures in lower zones result in vertical ground-water flow from lower to upper layers. The rate of this flow is dependent on the difference in hydraulic heads and the hydraulic conductivity and thickness of the intervening clay layers.

Separation of ground-water flow into distinct zones probably also occurs within most of the volcanic deposits near Tinemaha Reservoir. Air vesicles formed near the top of individual volcanic flows and clinker zones formed at the top and bottom make the material between flows more permeable than the material in the center of a flow. However, vertical fractures that developed after the flows had cooled might permit water to move from one permeable zone to another. If the fractures are not uniformly distributed, then the partial interconnection of flow paths could create a confusing distribution of hydraulic heads and could cause both confined and unconfined responses within short distances.

Los Angeles Department of Water and Power (1976) produced maps showing contours of two general potentiometric surfaces for ground water in the valley. Plate VIII-4 in that report is for an upper, unconfined zone just below the land surface. Plate VIII-7 is for a composite lower, confined zone that ranges in depth from 100 to 600 feet beneath the 1 and surface. The plates show ground-water conditions in March 1974. Another map by Los Angeles Department of Water and Power (1972, plate II-H) shows contours for the lower zone in August 1970 prior to increases in ground-water pumpage. Figures 4A and $4 B$ have been adapted from the contour maps published by Los Angeles Department of Water and Power for the upper zone in 1974 and for the Tower zone in 1970, respectively. Horizontal components of ground-water flow are approximately perpendicular to the potentiometric contours. 
Hydraulic Characteristics

Hydraulic characteristics of the ground-water system describe the ability of aquifer materials to transmit and to store water. These characteristics include saturated thickness, hydraulic conductivity, transmissivity, and storage coefficient.

\section{Saturated thickness}

Saturated thickness refers to that part of the total thickness of alluvial deposits in which voids between the particles or with in fractures are completely filled with water. Pakiser and others (1964) estimated that the maximum depth of alluvial deposits in the middle of the valley ranges from 4,000 feet near Bishop to about 3,000 feet near Tinemaha Reservoir to more than 8,000 feet beneath Owens Lake. Nearly all this material is saturated; however, the great degree of compaction at depth limits the quantity of water that can be stored or transmitted. Water wells in the valley provide a significant stress to the ground-water system, but they generally do not exceed 700 feet in depth. Although pumping induces an upward movement of ground water from below the well, the total saturated thickness providing water to wells is probably less than 1,000 feet. Therefore, it is likely that ground water in most of the deeper parts of the valley does not move rapidly, nor interact significantly with ground water in the upper 1,000 feet of saturated deposits. An exception to this may be in geothermal areas near Bishop. The presence of Keough Hot Springs and flowing wells with warm water near the Owens River both indicate that circulation of ground water may involve deeper parts of the valley. The significance of a deeper circulation pattern is not known.

The total thickness of saturated material in the alluvial fans and volcanic deposits is largely a matter of conjecture. No wells have been drilled that have penetrated the entire alluvial sequence in these areas. Previous geophysical studies of Owens Valley have concentrated on the deepest parts of the valley and have not determined either the total or saturated thickness of alluvial deposits along the sides of the valley.

Cross sections showing the land surface and water table (Los Angeles Department of Water and Power, 1972; Griepentrog and Groeneveld, 1981) permit a rough estimate of saturated thickness under the alluvial fans. By extrapolating these two surfaces, a range of values for saturated thickness can be obtained. At the head of the fans, mountains rise steeply away from the basin. If this slope continues a short distance under the alluvial fans, the total thickness of alluvial deposits would increase rapidly toward the center of the valley. For example, near Independence the total alluvial thickness would exceed 1,200 feet halfway down the fan. An observation well in the same area indicates a depth to water of about 500 feet. Therefore, the saturated thickness at this point could be as much as 700 feet. Above this point on the fan, saturated thickness appears to decrease to about 200 feet. Toward the center of the valley, saturated thickness could increase to approximately 2,000 feet at the toe of the fan, as indicated by measured water levels and seismic refraction data analyzed by Pakiser and others (1964). Similar patterns of saturated thickness probably characterize other alluvial fans, particularly those along the western side of the valley. 

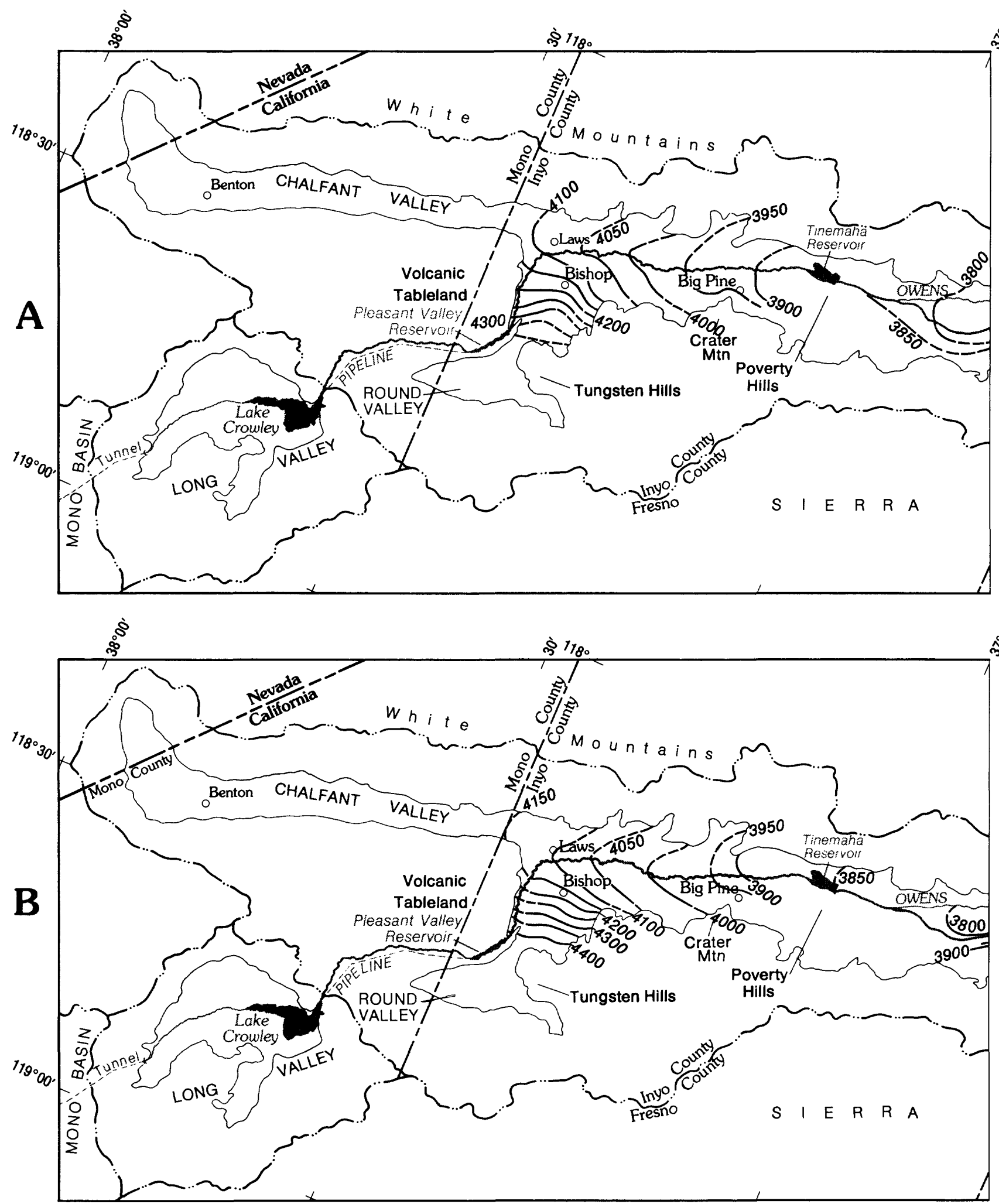

FIGURE 4. - Contours of measured hydraulic heads for (A) an upper unconfined zone during March 1974 (adapted from Los Angeles Department of Water and Power, 1976, plate VIII-4), and (B) a composite lower confined zone during August 1970 (adapted from Los Angeles Department of Water and Power, 1972, plate II-H). 


\section{Hydraulic conductivity and transmissivity}

Hydraulic conductivity describes the ability of aquifer material to transmit water. For example, gravel has a much higher hydraulic conductivity than clay. Horizontal movement of water is described by transmissivity, which is the product of horizontal hydraulic conductivity and saturated thickness of an aquifer. For example, the rate at which water can be extracted from a we 11 is directly related to the transmissivity of the aquifer--the higher the transmissivity, the greater the rate at which water can be extracted.

The horizontal hydraulic conductivity and transmissivity of the aquifer materials have been estimated in two ways. First, pumping tests on wells have been conducted by Los Angeles Department of Water and Power. Most of the tests were specific capacity measurements or transmissivities calculated using a semilog analysis of hydraulic-head and pumping data. The specific-capacity measurements are generally less accurate, but can be converted to approximate transmissivities using the relation that 1.25 times specific capacity equals transmissivity in consistent dimensional units. This approximation can be derived from the Thiem equation for steady-state flow by applying reasonable assumptions about the extent of the drawdown cone and well loss. Todd (1959) presented assumptions and derivation of the Thiem equation. Calculated values of transmissivity for pumping tests and specific-capacity measurements were summarized by W.F. Hardt (U.S. Geological Survey, written commun., 1984). Transmissivity of alluvial materials in the middle of the valley ranged from 4,000 to $70,000 \mathrm{ft}^{2} / \mathrm{d}$. Using an average depth of 500 feet for the pumped we 11 and assuming no vertical flow from deeper materials, the corresponding hydraulic conductivity would range from 8 to $140 \mathrm{ft} / \mathrm{d}$. In the volcanic deposits near Big Pine, transmissivity is much greater, sometimes in excess of $1,300,000 \mathrm{ft}^{2} / \mathrm{d}$. Because well depths are generally less in volcanic areas, this transmissivity value corresponds to an average hydraulic conductivity of $5,000 \mathrm{ft} / \mathrm{d}$.

Because most pumping tests were conducted on production wells, the areal distribution of transmissivity estimates is uneven. For example, in the southern part of the valley, nearly all tests were conducted on wells close to the aqueduct. No data are available for transmissivity on the alluvial fans or in the central and eastern parts of the valley. In addition, most of the production wells are perforated in numerous zones, both unconfined and confined. Observation wells are typically perforated over a narrower range of depths than the production wells. This inconsistency in perforation intervals between production and observation wells can adversely affect the estimates of aquifer characteristics.

The second method of estimating transmissivity was used by D.E. Williams (1969) in developing a ground-water model for the Independence area. Guided by data from a few pumping tests, D.E. Williams adjusted values of transmissivity in the model in order to match measured water levels. An advantage of D.E. Williams' model was that it had broad areal coverage, from the Poverty Hills to the Alabama Hills, and from the base of the mountains on the western side of the valley to the Owens River. However, the transmissivity values were not all mutually consistent. The particular ground-water model formulation used by D.E. Williams was developed by Tyson and Weber (1964) and permits each side of a polygonal area to have a different transmissivity. As a result in some cases, adjacent sides of the same polygon 
had transmissivity values that differed by a factor of 10 . This difference could result if the aquifer materials were anisotropic--if they had a greater ability to transmit water in one horizontal direction than in another. However, D.E. Williams did not discuss the observed or inferred presence of anisotropic conditions in Owens Valley. Despite these possible inconsistencies, the general transmissivity values were consistent with data from pumping tests, except in the volcanic areas where the model values were substantially lower. D.E. Williams' values of transmissivity on the alluvial fans ranged from 650 to $2,700 \mathrm{ft}^{2} / \mathrm{d}$; values in the middle of the basin ranged from 1,350 to $9,400 \mathrm{ft}^{2} / \mathrm{d}$; and values in the volcanic areas ranged from 6,000 to $12,000 \mathrm{ft}^{2} / \mathrm{d}$.

Neither the pumping tests, nor the ground-water model provide estimates of transmissivity values in the lakebed deposits or in extensively faulted areas such as the one north of the Alabama Hills. One possible method to extrapolate available transmissivity data to other areas of the valley involves using generalized relations between types of aquifer material and hydraulic conductivity values (Freeze and Cherry, 1979; Lohman, 1979; DeWiest, 1969). For example, the hydraulic conductivity of well-sorted sand typically ranges from 13 to $130 \mathrm{ft} / \mathrm{d}$. Multiplying this range by an estimate of the saturated thickness of sand yields a range of transmissivity values. This method is a poor substitute for a pumping test; however, it may provide useful initial estimates in areas with no other information.

\section{Vertical hydraulic conductivity}

When only the vertical movement of water is considered, the term "vertical hydraulic conductivity" is used to describe the ability of the aquifer to transmit water. This is a particularly important characteristic in a layered ground-water system such as in Owens Valley. Vertical hydraulic conductivity in combination with the difference in hydraulic head between two layers determines the rate of water movement between them. Because the hydraulic conductivity of clay is much less than for either sand or gravel, the presence of clay usually exerts a strong control over the vertical movement of water in alluvial deposits. For example, the presence of a clay layer may not markedly decrease the horizontal transmission of water because water can follow parallel flow paths through adjacent sand and gravel layers. However, a clay layer that is laterally extensive may significantly retard the vertical transmission of water. Because recharge and withdrawal of ground water in Owens Valley commonly occur at different depths, vertical hydraulic conductivity probably plays a large role in determining ground-water-flow patterns and rates.

No values of vertical hydraulic conductivity are available for any part of Owens Valley. A few values in key areas of the valley would significantly improve the understanding of the ground-water system in owens valley. Three methods typically are used to determine vertical hydraulic conductivity. Laboratory measurements can be used to determine the vertical hydraulic conductivity of core samples taken from the aquifer. Aquifer tests with both a pumping well and multiple observations wells can be conducted which yield field values for vertical hydraulic conductivity. Finally, a ground-waterflow model can be used to estimate vertical hydraulic conductivity using a method of trial-and-error adjustment to match measured hydraulic-head data. 
The storage coefficient of an aquifer is the quantity of water the aquifer will yield per unit area per unit decline in hydraulic head and is expressed as a dimensionless value. In an unconfined aquifer, water is derived by actual dewatering of the aquifer material. Under these conditions, storage coefficient is referred to as specific yield and ranges from 5 to 20 percent of the decline in head. In a confined aquifer, water is derived from expansion of the water and compaction of aquifer materials. Under these quite different conditions, storage coefficients generally range from 0.0010 to 0.00001 of the decline in head.

Determination of storage coefficients for a particular aquifer is relatively difficult. The most effective techniques involve either analysis of a multiple-well aquifer test or calibration of a transient, ground-waterflow model. Both of these techniques have been applied to the Owens Valley ground-water system. Los Angeles Department of Water and Power conducted numerous tests of individual pumping wells. Some of these tests also included measurements of hydraulic heads in nearby observation wells. W.F. Hardt (U.S. Geological Survey, written commun., 1984) summarized the calculated results for the multiple-well tests and found that the storage coefficients ranged from 0.01 to 0.000001 . However, these values were developed using the assumption that the ground-water system consists of a single, confined aquifer. In reality it consists of a combination of confined and unconfined zones. The wide range of values reported by Hardt suggest that both types of zones were tested.

As part of developing a transient, ground-water-flow model for the southern part of Owens Valley, D.E. Williams (1969) assigned storage coefficients for each of 25 polygonal areas. The calibrated values ranged from 0.15 to 0.025 , which suggest unconfined conditions. However, the ground-water-flow model was used to simulate a single aquifer assumed to be unconfined on the alluvial fans and confined beneath the middle of the valley. No explanation for the high storage coefficients in the confined area was given by D.E. Williams, but it probably resulted from the simulation of confinement in an area known also to have an unconfined zone.

\section{Water Budget}

A water budget is central to nearly all hydrologic investigations, particularly those involving numerical simulations. Regardless of the type of system being investigated, a water budget summarizes the separate components of inflow, outflow, and change in storage for that particular system. For example, a water budget of the entire Owens Valley would involve each of the inflows to the valley, each of the outflows from the valley, and the change in storage within the surface-water reservoirs and the ground-water system. A separate water budget could be developed for the surface-water system or the ground-water system. Additional water budgets might be useful for individual streams or the aqueduct. Ideally, all the water budgets would be consistent with one other. For example, the quantity of stream recharge that is used as outflow from the surface-water system would be identical to the quantity of 
stream recharge that is used as inflow to the ground-water system. In practice, it is usually difficult to develop each of these water budgets for identical time periods and areas of the valley.

Most water budgets are created using a lumped approach. That is, an item in the budget, such as evapotranspiration, is lumped into a single value for the entire system even though it may have originally been calculated for separate areas in the valley. In contrast, using a distributed approach involves calculating a complete water budget for individual areas distributed throughout the system. This latter approach assures that the water budget is valid not only for the system as a whole, but also for each of the individual subareas. Errors which might coincidently cancel each other in a lumped budget frequently become obvious in a distributed budget. One of the primary advantages of using distributed-parameter models to simulate either the surface-water or ground-water system is that the models calculate a water budget for each of many small subareas.

A particularly convenient type of water budget involves steady-state or equilibrium conditions for the system being studied. Under these conditions, total inflow equals total outflow. This can be true only if the change in storage is zero. For a ground-water budget, equilibrium conditions also imply that hydraulic heads at the beginning and end of the steady-state period must be equal.

Several previous investigations have summarized water budgets for the hydrologic system in Owens Valley. C.H. Lee (1912) estimated some of the components of an overall water budget for the southern part of Owens Valley using data collected from 1908 to 1911. Conkling (1921) summarized surface water conditions in Mono Basin, Long Valley, and the northern part of Owens Valley for the period 1895 to 1920 in order to evaluate the potential siting of an additional reservoir. California Department of Water Resources (1960) compiled values of surface-water runoff and estimated water utilization in Mono Basin, Long Valley, and Owens Valley for an unspecified period of time between 1894 and 1959. An imbalance of about 10 percent between inflow and outflow was attributed to unquantified use and deep percolation of precipitation. D.E. Williams (1969) compiled a generalized water budget for the area of Owens Valley between Big Pine and Haiwee Reservoir for water years 1938-60.

A much more complete analysis was presented by Los Angeles Department of Water and Power (1972) using data for water years 1935-69, during which time both the surface-water and ground-water systems were assumed to be in equilibrium. The part of Owens Valley that was evaluated extends from north of Bishop, excluding Round Valley, to south of Lone Pine, including Owens Lake. This budget was later revised by Los Angeles Department of Water and Power (1976) to include only water years 1936-66 because it was thought that the budget should not end with an extremely wet year. More important, the valleywide water budget published in their 1972 report was expanded to include three separate budgets: a budget for the entire drainage basin, a combined surface- and ground-water budget for the alluvial part of the basin, and a ground-water budget. The only major budget missing from the analysis was one for the surface-water system itself. Los Angeles Department of Water and Power (1976) also calculated the three water budgets for a period that was not in equilibrium, water years 1971-74. Because this was a period of significant 
change in both water operations and ground-water storage, values for the nonequilibrium budgets may be less reliable than those for the steady-state budgets. Los Angeles Department of Water and Power in two subsequent reports (1978, 1979) briefly reiterated the budgets presented in the 1976 report. Some components of the nonequilibrium budgets were extended through the drought of 1976-77, but a complete water budget for the extended period was not calculated. Griepentrog and Groeneveld (1981) developed a detailed schematic of a valleywide water budget, but did not calculate specific values.

The studies cited above are difficult to compare because they cover either different areas or different periods of time. In addition, some of the budgets use the same components of inflow and outflow, but with slightly different definitions. Nevertheless, values presented in those reports are useful in developing an overall impression of the hydrogeologic system in Owens Valley. For this reason, the general components of inflow, outflow, and storage in the valley are presented separately below. Note that inflow to one system may constitute outflow from another. Whenever possible, the physical process that governs the inflow or outflow also is described.

A more complete analysis of the hydrogeology of Owens Valley would require at least three interrelated water budgets: one for the entire drainage basin, one for the surface-water system, and one for the ground-water system. The budgets need to be developed for the same area and time period. Either equilibrium or nonequilibrium conditions could be used for the budgets, although the storage component is harder to quantify for nonequilibrium conditions. Ideally, the time period selected would reflect the current operation of the hydrologic system.

\section{Inflow}

\section{Precipitation}

Precipitation varies considerably throughout Owens Valley. Precipitation in the form of both snow and rain falls along the western edge of Owens Valley as moisture-laden airmasses move eastward across the Sierra Nevada. The valley floor and eastern edge of the valley are in a rain shadow, and consequently receive much less precipitation. In general, precipitation also decreases from north to south.

Los Angeles Department of Water and Power (1972, plate II-D) presented a map showing lines of equal mean annual precipitation for water years 1935-69. The map was compiled using data from 21 stations, although no stations were available along the eastern side of the valley. Using this map, Los Angeles Department of Water and Power estimated that an average of 343,000 acre-ft/yr falls on the valley fill, an area defined by Los Angeles Department of Water and Power as the part of Owens Valley excluding hill and mountain areas. As a long-term average this value is probably fairly accurate; however, annual precipitation rates for Owens Valley vary significantly--from more than 200 percent of the long-term mean to less than 20 percent. 
Percolation to the ground-water system from precipitation was estimated by C.H. Lee (1912, p. 66-67) for three main areas in the southern part of Owens Valley. He estimated that on the intermediate mountain slopes between 6,500 and 12,000 feet above sea level as much as 75 percent of precipitation percolates to the ground-water system. On the alluvial fans the amount was estimated to be only 16 percent, and on the valley floor, where the depth to ground water is only a few feet, less than 10 percent. Because of the semiarid conditions prevailing in the lower altitudes of the valley, most of the precipitation falling on the ground-water basin remains briefly in the soil-moisture zone and then either evaporates or is used by plants. Only a small percentage percolates to recharge the ground-water system.

Using data collected for the three areas, C.H. Lee (1912) estimated that as much as 32,000 acre-ft/yr percolated to the ground-water system between Charlie's Butte and Lone Pine (fig. 1). More than half of this occurred on the intermediate mountain slopes above 6,500 feet. Los Angeles Department of Water and Power (1976) estimated percolation from precipitation for all of Owens Valley, excluding Round Valley, to be 94,000 acre-ft/yr, or about 25 percent of the total precipitation estimated to fall on the valley fill. If the lower percolation rates estimated by C.H. Lee were used for the southern part of the valley, then the average rate within the Bishop area would have to be significantly greater than 25 percent.

Although the quantity of precipitation falling on the valley can be measured accurately, the quantity of percolation to the ground-water system from precipitation is much more difficult to determine. In fact, for most of the valley, in particular along the alluvial fans, no actual measurements of percolation have been made.

\section{Owens River}

With its headwaters in Long Valley, the Owens River flows in a pipeline through the Volcanic Tableland and into Owens Valley at Pleasant Valley Reservoir. Although leaks in the pipeline are possible, the quantity of recharge to the ground-water system is probably minimal. The river outflow from Pleasant Valley Reservoir has been measured continuously and averaged 246,000 acre-ft/yr for water years 1935-69 (Los Angeles Department of Water and Power, 1972, p. IV-3). Average flow for water years 1936-66 was 243,000 acre-ft/yr (Los Angeles Department of Water and Power, 1976).

The Owens River between Pleasant Valley Reservoir and Owens Lake is measured routinely at only three points: Tinemaha Reservoir, just south of the intake to the Los Angeles Aqueduct, and east of Lone Pine at Keeler Bridge. South of Tinemaha Reservoir, data for the Owens River typically has been combined with data for the Los Angeles Aqueduct. When the two channels are considered together, they will be referred to as the river-and-aqueduct system. From Pleasant Valley Reservoir to Owens Lake (for the river) and to Haiwee Reservoir (for the aqueduct), the river-and-aqueduct system gained an average of $72,000 \mathrm{acre}-\mathrm{ft} / \mathrm{yr}$ before 1970 when most of the gains were from diversions of streamflow and as much as 166,000 acre-ft/yr after 1970 when the diversions were augmented with ground-water pumpage (Los Angeles Department of Water and Power, 1976). 
Interaction of the river-and-aqueduct system with the ground-water system has not been measured and has been estimated only as the residual term in surface-water budgets. Using this approach, Los Angeles Department of Water and Power (1972) estimated that during the steady-state period, water years 1935-69, the Owens River gained about 9,400 acre-ft/yr from the ground-water system between Pleasant Valley Reservoir and Tinemaha Reservoir. For another period, water years 1945-73, Los Angeles Department of Water and Power (1976) estimated that the Owens River gained 4,400 acre-ft/yr from the ground-water system in the Bishop area and 2,200 acre-ft/yr in the Big Pine area.

Between Tinemaha Reservoir and Owens Lake, the river is believed to both gain and lose water depending upon the particular reach (M.L. BTevins, Los Angeles Department of Water and Power, oral commun., 1984). Los Angeles Department of Water and Power (1972) estimated that the river-and-aqueduct system south of Tinemaha Reservoir lost approximately 25,000 acre-ft/yr to the ground-water system. However, this estimate was calculated simply as a percentage of the inflow to Haiwee Reservoir. In a separate analysis, Los Angeles Department of Water and Power (1976, table III-1) estimated that the river-and-aqueduct system lost $8,700 \mathrm{acre-ft} / \mathrm{yr}$ to the ground-water system in the Independence area and gained $700 \mathrm{acre}-\mathrm{ft} / \mathrm{yr}$ in the Lone Pine area. Because estimates of gains and losses for Owens River are combined with estimates for the aqueduct, much of the information about surface-water and ground-water interactions is lost. For example, in the Lone Pine area, it is unclear whether the aqueduct and river are both gaining water, or whether the river is simply gaining more water than the aqueduct is losing, or whether the river is actually losing water and the aqueduct gaining. The important point is that each possible situation results in a substantially different concept of the ground-water-flow system.

Discharge from the Owens River into Owens Lake is measured continuously at Keeler Bridge, east of Lone Pine. D.E. Williams (1969) calculated that for water years 1938-60 discharge at Keeler Bridge averaged 20,000 acre-ft/yr. Because nearly all water flowing out of Tinemaha Reservoir is diverted into the aqueduct, most water that reaches Owens Lake is a result of seepage from the ground-water system into the river. An exception to this would be during wet years when some of the streamflow and discharge from springs is not diverted into the aqueduct.

The interaction of the Owens River with the ground-water system probably cannot be estimated accurately without continuous discharge measurements at several sites along the length of the river. Prior estimates using the residual term of a water budget are subject to the cumulative errors of all other items in the budget. Because estimates of small gains or losses from measurements of discharge are also subject to significant errors, additional measurements of the hydraulic gradient from the ground-water system to the stage in the river may be useful. The gaining and losing reaches of the river can then be inferred from the direction of the hydraulic gradient. 
More than 30 streams along the western side of Owens Valley gain water from drainage areas in the Sierra Nevada, flow out across the alluvial fans, and empty into the valley. Because of the abundant snowpack in the mountains, these streams contribute approximately one-third of the total inflow to the valley.

C.H. Lee (1912) used short-term discharge data for selected streams in the southern part of Owens Valley, in combination with long-term records for other basins in southern California, to describe the general characteristics of streamflow. California Department of Water Resources (1960) summarized historical streamflow records for Long, Round, and Owens Valleys, but did not report separate values for each valley. As part of a ground-water modeling study, D.E. Williams (1969) estimated that average inflow from streams in the southern half of Owens Valley was 207,000 acre-ft/yr for water years 1938-60.

Los Angeles Department of Water and Power (1972) estimated that total runoff from the mountainous areas surrounding Owens Valley averaged 320,000 acre-ft/yr for water years 1935-69. A similar value of 315,000 acre-ft/yr was calculated by Los Angeles Department of Water and Power (1976) for another steady-state period, water years 1936-66. The accuracy of these estimates is probably good because 80 percent of the inflow was calculated using records from gaging stations located near the base of the mountains on each stream. Runoff from ungaged areas was assumed to be the difference between precipitation and percolation. Precipitation was calculated using a map of mean annual precipitation on the valley and mountain areas (Los Angeles Department of Water and Power, 1972, plate II-D), and percolation was calculated using rates from C.H. Lee (1912). Although the method of calculating runoff from ungaged areas is reasonable, the level of accuracy is not known. Different assumptions about percolation rates or a different contouring of precipitation might produce substantially different values of runoff from the ungaged areas.

Recharge from streams contributes nearly all the inflow to the ground-water system. C.H. Lee (1912) provided the first estimates of stream recharge by studying 13 streams near Independence. He determined that the quantity of recharge was dependent on time of year and different channel conditions, and produced several graphs showing those relations for selected streams. The graphs indicate that an average recharge rate would be between 35 and 50 percent of the discharge measured at the base of the mountains. C.H. Lee noted, however, that his calculations were for a stream segment from the base of the mountains to a gage near the toes of the fans, and that additional recharge probably occurs downstream from this gage, possibly increasing the total recharge rate by 10 to 15 percent. 
Since C.H. Lee's work, Los Angeles Department of Water and Power installed gaging stations on each of the major streams both at the base of the mountains and near the toe of the fans. Using a mass-balancing technique similar to C.H. Lee's, Los Angeles Department of Water and Power (1976) estimated that total recharge to the Owens Valley ground-water system from streamflow averaged 192,000 acre-ft/yr for water years 1936-66. This value includes both streamflow losses, such as those estimated by C.H. Lee (1912), and purposeful diversions of streamflow (uses) such as for irrigation. Estimates of stream recharge are probably more accurate than any other component of the ground-water budget.

Quantifying each of the agricultural diversions, particularly in the Bishop area, has not been done, and may not be possible. Estimates of water use and ground-water recharge made by Los Angeles Department of Water and Power (1976) were based primarily on the type of 1 and cover and estimates of average consumptive use. During years with an abundance of runoff, excess water is diverted from streams and canals and spread across the alluvial fans and the valley floor to promote ground-water recharge. Most of these operations have not been quantified so that the effect of these diversions on the ground-water system is largely unknown.

\section{Underflow}

The granitic and metamorphic rocks that surround and underlie the alluvial part of Owens Valley tend to isolate the ground-system from subsurface inflows. Although minor flows through fractures in the bedrock are possible and are, in fact, indicated by elevated temperatures in some wells in the Bishop area, all previous studies have assumed that this inflow is virtually zero. The Owens Valley ground-water system north of Bishop seems to be connected to the Long Valley system by alluvial deposits more than 1,000 feet thick underlying the Volcanic Tableland. This area prompted C.H. Lee (1912, p. 11) to comment that the "lava sheet has buried the original topography between Long Valley and Owens Valley so that it is difficult to determine to what extent the underflow is cut off, but numerous springs emerging from the lower edge of the lava indicate an outlet through and beneath it."

California Department of Water Resources (1960) also recognized the potential for ground-water flow between Long Valley and Owens Valley, : but did not offer any estimates of the quantity. Los Angeles Department of Water and Power (1972, 1976) assumed that although some flow might enter Owens Valley beneath the Volcanic Tableland, the quantity was negligible. However, Los Angeles Department of Water and Power did assume that significant underflow probably occurs from both Round Valley and Chalfant Valley. Inflow from each valley was calculated by applying Darcy's Law to the cross-sectional area of the alluvial deposits and the slope of the water table. Estimated inflow was 14,000 acre-ft/yr from Round Valley and 11,000 acre-ft/yr from Chalfant Valley (Los Angeles Department of Water and Power, 1976, table II-5). 
Outflow

Evapotranspiration

Evapotranspiration is the least understood element of the water budget. Because no actual measurements of evapotranspiration have been made, most studies have estimated evapotranspiration as the residual of a water budget. This approach lumps all errors made in calculating other items of the water budget into the value for evapotranspiration. Because there is no independent check on the value for evapotranspiration, the entire water budget is less reliable. The few studies that attempted to independently calculate a value for evapotranspiration used either pan evaporation data or evapotranspiration data for grasses, such as alfalfa. Neither of these conditions are representative of most areas in Owens Valley.

The first estimates of evaporation and transpiration in Owens Valley were made by C.H. Lee (1912). Using evaporation pans, he calculated that evaporation from a free water surface ranged from 67 to $85 \mathrm{in} / \mathrm{yr}$. In order to measure evapotranspiration, C.H. Lee installed lysimeters covered with bare soil or salt grass. By varying the depth to saturation, he was able to estimate the quantity of evapotranspiration that would occur for those particular soil covers in areas of the valley with different depths to ground water. For an area of $54.8 \mathrm{mi}^{2}$ in the southern part of Owens Valley, C.H. Lee calculated an annual evapotranspiration of approximately 67,000 to 83,000 acre-ft/yr. This is equivalent to an average rate of 22 to $28 \mathrm{in} / \mathrm{yr}$.

California Department of Water Resources (1960) tabulated evaporation rates for each of the reservoirs: $4.5 \mathrm{ft} / \mathrm{yr}$ for Pleasant Valley, $5.5 \mathrm{ft} / \mathrm{yr}$ for Tinemaha, and $3.9 \mathrm{ft} / \mathrm{yr}$ for Haiwee. These values correspond to volumetric rates of $500 \mathrm{acre}-\mathrm{ft} / \mathrm{yr}, 5,700 \mathrm{acre}-\mathrm{ft} / \mathrm{yr}$, and 4,600 acre-ft/yr, respectively. In order to estimate evapotranspiration on the valley floor, the investigators assumed that for an average depth to water in the valley of 3 feet, a reasonable value of evapotranspiration would be $2.5 \mathrm{ft} / \mathrm{yr}$. Using estimates of the acreage of high ground water from C.H. Lee (1912) and Conkling (1921), they calculated a value of 250,000 acre-ft/yr. Evaporation from Owens Lake was assumed to be 10 percent of this value or 25,000 acre-ft/yr. These values do not include evapotranspiration from areas without high ground water.

D.E. Williams (1969) estimated that evapotranspiration in the area from just north of Big Pine south to Haiwee Reservoir averaged 193,000 acre-ft/yr during water years 1938-60. In most areas, evapotranspiration was calculated as a residual in the water budget. In areas where the depth to water was less than 8 feet, D.E. Williams estimated a rate of $2.6 \mathrm{ft} / \mathrm{yr}$ by using a method developed by Thornthwaite (1931). 
Los Angeles Department of Water and Power (1972, table IV-A) estimated that evapotranspiration for all of Owens Valley averaged $610,000 \mathrm{acre}-\mathrm{ft} / \mathrm{yr}$ for water years 1935-69. Evaporation from Tinemaha and Haiwee Reservoirs was estimated to be 14,000 acre-ft/yr. Consumptive use from irrigated lands, primarily in the Bishop, Laws, and Big Pine areas, was assumed to equal 50 percent of the water applied, or 210,000 acre-ft/yr. Evapotranspiration from urban and suburban areas was estimated to be 3,000 acre-ft/yr using results from a 1958 land use survey by California Department of Water Resources. Evapotranspiration from high-ground-water areas was estimated to be 260,000 acre-ft/yr, or $2.6 \mathrm{ft} / \mathrm{yr}$. A residual of $313,000 \mathrm{acre}-\mathrm{ft} / \mathrm{yr}$ in the water budget was assumed to represent evapotranspiration over the remainder of the study area. This value equals a linear rate of $0.5 \mathrm{ft} / \mathrm{yr}$.

Los Angeles Department of Water and Power (1976, table VI-1) used a similar, but more detailed approach to estimate evapotranspiration for individual areas of the valley. The method involved using land-use patterns identified from aerial mapping of Owens Valley and generalized relations between evapotranspiration and depth to water for individual plant species (Los Angeles Department of Water and Power, 1976, plates IV-5,6). The relations were selected from data published for other semiarid basins. Total evapotranspiration for the valley was estimated to average 594,000 acre-ft/yr. The individual values were: 239,000 acre-ft/yr from high-ground-water areas; 36,000 acre-ft/yr from irrigated areas; 243,000 acre-ft/yr from precipitation on valley-fill areas; 14,000 acre-ft/yr from reservoir evaporation; 3,600 acre-ft/yr from urban areas; and 60,000 acre-ft/yr from hill and mountain areas.

Griepentrog and Groeneveld (1981) did not calculate a complete water budget for the valley, but did estimate average evapotranspiration rates for the valley based on percentage of vegetative cover, depth to water, and quantity of precipitation. The rates that D.P. Groeneveld (Inyo County Water Dept., written commun., 1984) estimated for the predominant areas of the valley were $4.7 \mathrm{in} / \mathrm{yr}$ for low, sparse desert vegetation; 6.6 in/yr for phreatophytes with an average density of cover and a depth to water of approximately 8 feet; $12.6 \mathrm{in} / \mathrm{yr}$ for meadow conditions; 36.0 in/yr for irrigated pasture; and $53.0 \mathrm{in} / \mathrm{yr}$ for open water or mudflats.

Springs and seeps

Springs occur in several parts of the valley including along the volcanic outcrops north of Bishop, along the Owens River east of Bishop, in the middle of the valley near Tinemaha Reservoir, and along fractures north of the Alabama Hills. Most localized springs discharge into small ditches or canals that replenish the soil-moisture zone, recharge the ground-water system, and may eventually empty into the Owens River. No springs result in direct flow out of the valley except as part of the river-and-aqueduct system. C.H. Lee (1912) estimated that average springflow into the Owens River was 8,000 acre-ft/yr from Upper and Lower Seeley Springs (currently referred to as Big and Little Seeley Springs) and 2000 acre-ft/yr from Blackrock Springs. An additional 11,000 acre-ft/yr of springflow was assumed to evaporate. No values were presented by C.H. Lee for springflows north of Tinemaha Reservoir.

Using historical records for water years 1936-66, Los Angeles Department of Water and Power (1976, p. VI-3) estimated a total discharge from springs

34 Hydrogeologic System in Owens Valley, California 
and flowing wells of 43,000 acre-ft/yr. For a similar period, water years 1935-69, Los Angeles Department of Water and Power (1972, table VI-A) calculated that discharge from flowing wells alone was 8,000 acre-ft/yr. The difference between these values, 35,000 acre-ft/yr, should approximately equal the average discharge from springs throughout the valley. The accuracy of these values or what percentage actually enters the Owens River is not known. Measurements of both springflow and discharge into the Owens River would aid in developing local estimates of evapotranspiration.

C.H. Lee (1912, p. 14) also noted that luxuriant growth occurred in a "spring zone, which is about a quarter of a mile wide and is situated at the upper edge of the valley floor." This area of ground-water seepage is well defined on infrared aerial photographs of the valley taken in 1983. Additional ground-water seepage was observed by C.H. Lee along the face of the 1872 fault scarp. Although no estimates of seepage rates or volumes has been made, it is likely that nearly all the seepage is eventually evaporated or transpired.

Griepentrog and Groeneveld (1981) compared topographic maps from 1913 and 1950 and found a significant reduction in the size of wet areas noted on the maps. This reduction could infer significantly less seepage and resulting evapotranspiration between the time of C.H. Lee's studies and more recent studies. However, some of the difference could also result from a difference in the artistry of map making.

\section{Pumpage}

Ground-water pumpage was not nearly as significant an item in the water budget before 1970 as it was after completion of the second aqueduct in August 1970. Prior to the second aqueduct, pumping occurred primarily in dry years (water years 1931 and 1961-62). For water years 1935-69, pumpage by Los Angeles Department of Water and Power averaged only 7,000 acre-ft/yr (Los Angeles Department of Water and Power, 1972). Most of this pumpage was conveyed into either the Owens River or the aqueduct. Approximately 20 percent of the pumpage occurred north of Tinemaha Reservoir and 80 percent south of the reservoir. Average pumpage from private wells during the same period was estimated to be 3,600 acre-ft/yr.

In contrast, for water years 1971-74, pumpage by Los Angeles Department of Water and Power was 112,000 acre-ft/yr (Los Angeles Department of Water and Power, 1976, table VI-2). This pumpage was also concentrated in the southern part of the valley although values for specific areas were not published. Because totalizing flowmeters were installed on production wells, Los Angeles Department of Water and Power can accurately compute discharge records for these wells. Discharge from flowing wells typically is estimated from v-notch weirs. Estimates of other pumpage throughout the valley are probably less reliable because most of the wells are not measured. Because discharge from production and flowing wells is conveyed to the river or aqueduct in pipelines and unlined ditches, some of the discharge from wells undoubtedly replenishes the soil-moisture zone and either leaves the valley as evapotranspiration or recharges the upper ground-water system. In addition, the quantity of withdrawal by wells from different zones of permeable material, for example on either side of a confining layer, has not been investigated. 
Aqueduct

The Los Angeles Aqueduct begins south of Tinemaha Reservoir where virtually all the flow in the Owens River is diverted westward into a large, unlined canal. Beginning at the Alabama Hills and continuing to Haiwee Reservoir, the aqueduct is lined with concrete. Spillgates used to flush accumulations of sand and debris from the aqueduct are located at various intervals.

Los Angeles Department of Water and Power (1972, 1976) estimated that average flow out of the valley in the aqueduct was 313,000 acre-ft/yr for water years 1935-69 and 311,000 acre-ft/yr for water years 1936-66. Because average inflow to the valley at Pleasant Valley Reservoir during those periods was about 246,000 acre-ft/yr, the river-and-aqueduct system gained approximately 72,000 acre-ft/yr along its route from surface-water diversions and from some ground-water pumpage. During water years 1971-74, surface-water diversions and pumpage into the aqueduct increased so that the river-andaqueduct system gained an average of 166,000 acre-ft/yr.

Published values of gains or losses in the aqueduct generally have been combined with gains and losses for the Owens River. In addition, continuous measurements of flow in the aqueduct are made only at the intake from the Owens River, on the north side of the Alabama Hills, and at Haiwee Reservoir. As a result, detailed interpretations of the interaction of the aqueduct with the ground-water system cannot be made.

Los Angeles Department of Water and Power (1976, table III-11) attempted to quantify gains and losses over large sections of the aqueduct for water years 1945-73. By measuring the flow of the Owens River out of Tinemaha Reservoir, measuring inflow from streams and pumped wells, estimating outflow through spillgates, and measuring outflow at the Alabama Hills, Los Angeles Department of Water and Power calculated a loss of 8,700 acre-ft/yr. This quantity was assumed to be lost to the ground-water system through the unlined reach of the river-and-aqueduct system. Water discharged out of the spillgates was estimated to equal $18,000 \mathrm{acre}-\mathrm{ft} / \mathrm{yr}$, of which 25 percent $(4,500 \mathrm{acre}-\mathrm{ft} / \mathrm{yr})$ was assumed to percolate to the ground-water system and 75 percent was assumed to evapotranspire. Thus, between 13,000 and 27,000 acre-ft/yr was added to the ground-water system in the vicinity of the aqueduct. Los Angeles Department of Water and Power developed a similar water budget for the aqueduct between the Alabama Hills and Haiwee Reservoir and noted a gain of $1,400 \mathrm{acre}-\mathrm{ft} / \mathrm{yr}$. Because of the inaccuracy inherent in measuring flow in the aqueduct and in estimating the various parts of the water budget, any estimates of gains or losses can be considered only approximate.

Hydraulic-head gradients in the ground-water system near the aqueduct also indicate whether water is seeping into or out of the aqueduct. Los Angeles Department of Water and Power (1972) developed cross sections perpendicular to the aqueduct showing the hydraulic-head surface of a confined zone beneath the aqueduct. This surface was above the top of the aqueduct in the area of Symmes Creek indicating that the aqueduct might be gaining water. Near Bairs and George Creeks, the surface was below the bottom of the aqueduct, indicating that the aqueduct might be losing water (fig. 1). 
Groeneveld and Griepentrog (1981) developed similar cross sections although they did not estimate the interaction of the aqueduct and ground-water system. Most of the cross sections show the aqueduct as potentially receiving or discharging water depending upon the local features of topography and the proximity of nearby streams. From the Alabama Hills to Haiwee Reservoir, the aqueduct seems to be much higher than the water table. Recharge to the ground-water system probably occurs throughout this reach, although at a slow rate because of the concrete lining. Cross sections north of the Alabama Hills using hydraulic-head data from 1912 to 1920 show the aqueduct and water table at the same altitude. Cross sections of the same area were developed using data for 1977, a period of below-average precipitation and heavy ground-water pumping, and show a hydraulic gradient from the aqueduct down to the water table. Thus, during periods of drought or heavy pumping, lowering of the water table may induce recharge from the aqueduct to the ground-water system.

\section{Underflow}

A small quantity of water may leave the ground-water system through fractures in the bedrock. Although this possibility is recognized, no outflow through bedrock has been detected using either geochemical or hydrothermal data.

Underflow out of the valley through alluvial deposits is unlikely except in the southern part of the valley, in particular south of Owens Lake near Haiwee Reservoir. Both C.H. Lee (1912) and Knopf (1918) stated that the presence of a bedrock barrier in that area prevents any possible ground-water outflow. Los Angeles Department of Water and Power (1972) postulated that a ground-water divide near Haiwee Reservoir would restrict ground-water flow out of the basin. However, seepage has been observed south of the reservoir. To account for this, Los Angeles Department of Water and Power used Darcy's law to estimate outflow through the alluvial deposits beneath Haiwee Reservoir and obtained an average rate of $11,000 \mathrm{acre}-\mathrm{ft} / \mathrm{yr}$ (Los Angeles Department of Water and Power, 1976, table II-5). The reservoir itself may be the source of the seepage. If this is the case, and if the reservoir does in fact straddle a ground-water divide, then water would also seep northward into Owens Valley.

\section{Storage}

\section{Surface water}

For convenience and to increase accuracy, most water budgets are developed for a time period during which the net change in surface-water and ground-water storage is approximately zero. For example, D.E. Williams (1969) calculated a water budget for the southern part of Owens Valley for water years 1938-60. For this period he estimated that there was no change in storage for Tinemaha Reservoir. Los Angeles Department of Water and Power (1972, p. IV-5) calculated a water budget for Owens Valley for water years 1935-69 and assumed that there was no change in surface-water storage. Los Angeles Department of Water and Power noted that the assumption does not take 
into account the monthly variations of reservoir storage. Los Angeles Department of Water and Power (1976) calculated a slightly different water budget for water years 1936-66. As with the 1935-69 budget, the change in storage for the surface-water system was assumed to be zero. In another budget, for water years 1971-74, Los Angeles Department of Water and Power (1976) assumed that the surface-water system lost an average of 7,000 acre-ft/yr.

\section{Ground water}

In general, changes in ground-water storage are far more difficult to assess than changes in surface-water storage. D.E. Williams (1969) estimated that the change in ground-water storage was zero for water years 1938-60. He noted, however, that the inflow and outflow were forced to balance by combining residual outflow with unknown seeps and springs. Los Angeles Department of Water and Power (1972) assumed that for water years 1935-69 there was no change in ground-water storage. This assumption does not necessarily imply that hydraulic heads were the same at the beginning and end of the period, only that increased heads in some areas were offset by decreased heads elsewhere. Los Angeles Department of Water and Power reasoned that the period was one of relatively high ground-water conditions and that any changes in ground-water storage were probably minor. The 1972 report included a hydraulic-head map for August 1970 for a deep, composite, confined zone, but did not include a similar map for an earlier time such as 1935 . No maps of a shallow, unconfined zone were included in the report.

For water years 1935-69, Los Angeles Department of Water and Power estimated that there was a net gain of 3,600 acre-ft/yr in ground-water storage. This quantity represents approximately 0.4 percent of the average inflow for the period. Errors of this magnitude could be expected from calculating almost any of the inflow or outflow components. A budget for water years 1971-74 showed a net loss of 109,000 acre-ft/yr from the ground-water system. This large storage change indicates that the hydrologic system in Owens Valley was not in equilibrium, which resulted primarily from a fifteenfold increase in ground-water pumping by Los Angeles Department of water and Power.

\section{SIMULATION OF THE GROUND-WATER-FLOW SYSTEM}

A ground-water simulation model is a group of mathematical equations that describe the flow of water through an aquifer. Variables (parameters) in the equations include hydraulic heads, transmissive characteristics, storage characteristics, and the rates of inflow and outflow. Different values for each variable, such as transmissivity or pumpage, can be distributed throughout the area being modeled in order to simulate observed spatial variations.

Even when using a distributed-parameter approach, however, not all characteristics of the actual hydrologic system can be included in the 
ground-water model. Simplifying assumptions are required to make the modeling effort manageable. Many of the assumptions used in developing the preliminary Owens valley ground-water model are characteristic of most numerical ground-water models. Explanations of these assumptions are given by Remson and others (1971), Wang and Anderson (1982), and Durbin (1978). Assumptions underlying the particular computer program used in this study are described by McDonald and Harbaugh (1984). Additional assumptions made in the application of the computer program to the Owens Valley system are discussed in appropriate sections later in this report.

Although a simulation model is only an approximation of the real world, it can be extremely useful in gaining an improved understanding of a complex system, in this case a ground-water system. For example, a ground-water-flow model assures that estimates of local aquifer characteristics, the water budget, and hydraulic heads are all compatible. In areas where data are sparse or uncertain, the model can be used to test the reasonableness of assumed values. Finally, a calibrated model, one for which all the parameter values are acceptable, can be used to compare the likely effects of different water-management strategies.

The preliminary ground-water model of Owens Valley described in this report was developed as an instructional aid, not as a predictive tool. As such it has several characteristics that might not be acceptable for a ground-water model designed for detailed study and analysis. In particular, calibration of the model was limited to steady-state conditions for a period of time that did not include significant ground-water pumpage. Also, aquifer characteristics were assumed to be uniform over broad hydrogeologic areas. Nevertheless, the model has enough complexity to yield useful overall impressions of the Owens Valley ground-water system and to guide the development of more detailed models.

\section{Computer Program}

A computer program developed by McDonald and Harbaugh (1984) was used to mathematically simulate the movement of ground water through the saturated alluvial and volcanic deposits in Owens Valley. This program uses standard finite-difference techniques to approximate the partial differential equations describing saturated ground-water flow. A discussion of these techniques and a detailed explanation of the computer program are presented by McDonald and Harbaugh (1984).

The use of finite-difference techniques requires dividing the study area into rectangular blocks, each assumed to have uniform aquifer properties. Figure 5 shows the particular finite-difference grid used for this study. A separate value of each variable used in the model is assigned to each block. The value represents an average for the entire block. Thus, water that actually comes out of an 8-inch well is simulated as if it were discharged uniformly from the entire surface of the block. As a result, this type of ground-water model does not simulate localized flows or water levels as 


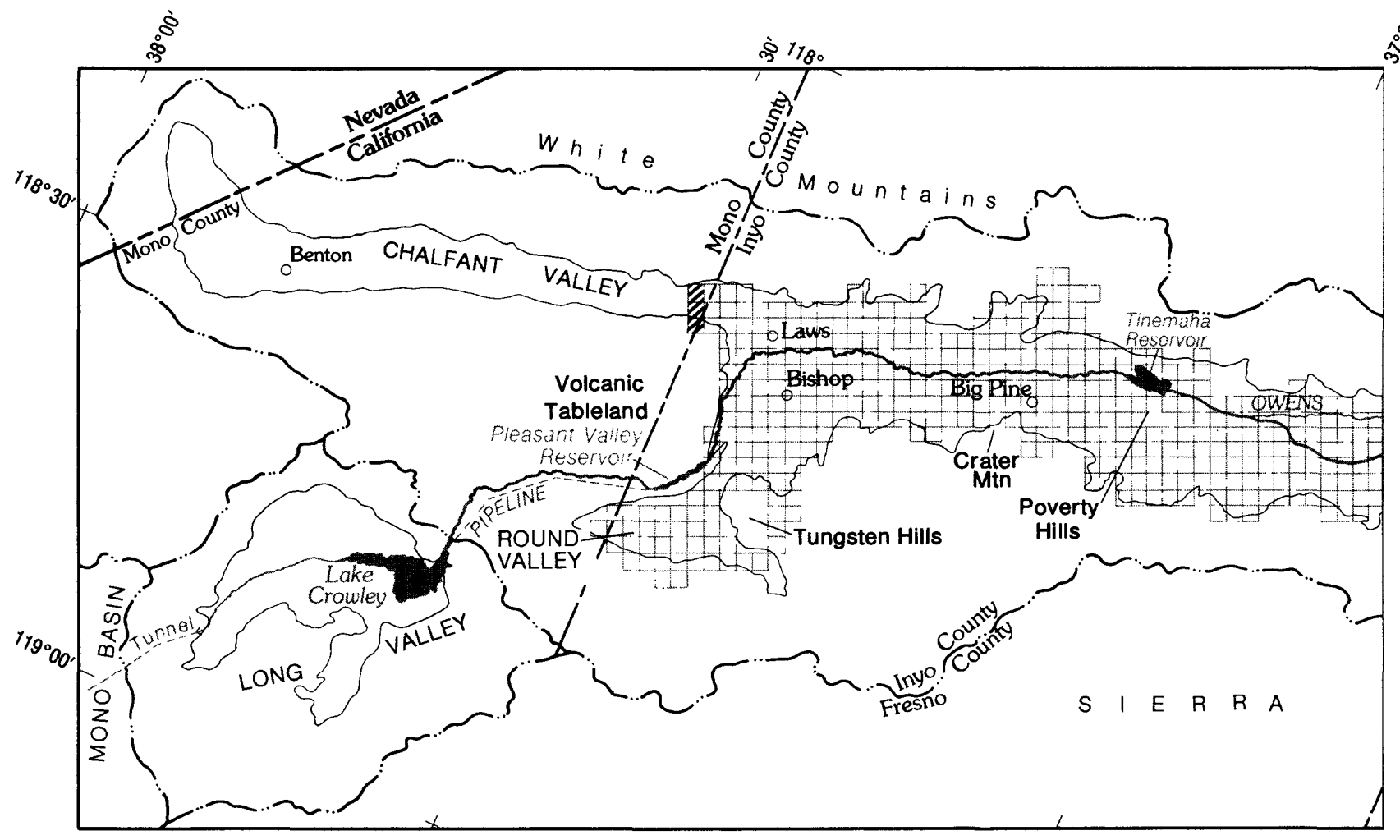

FIGURE 5. - Finite-difference grid and boundary conditions used for both layers of the ground-water-flow model.

accurately as it does more regional ones. A larger number of smaller blocks increases the spatial resolution of the model, but also increases the number of variables and the input data required for the model. For this study a compromise between the available data and the desired level of detail resulted in a uniform array of square blocks, each 1 mile on a side.

In the vertical dimension, the ground-water system is represented in the model by a series of layers. Typically, each layer represents a separate zone of the ground-water system and has the same areal pattern of finite-difference blocks (fig. 5). The thickness of an individual block within a layer is determined by the thickness of the aquifer material and can vary from one block to another. The hydraulic head is calculated by the model for the three-dimensional center of each block, commonly referred to as a node. Horizontal flow within each layer is assumed to be directly proportional to the hydraulic-head gradient. This assumption is accurate as long as saturated thickness at any location in the model does not vary significantly during simulations. Vertical flow between model layers is determined by the hydraulic head in each layer and by the vertical hydraulic conductivity. and thickness of any intervening clay material. 


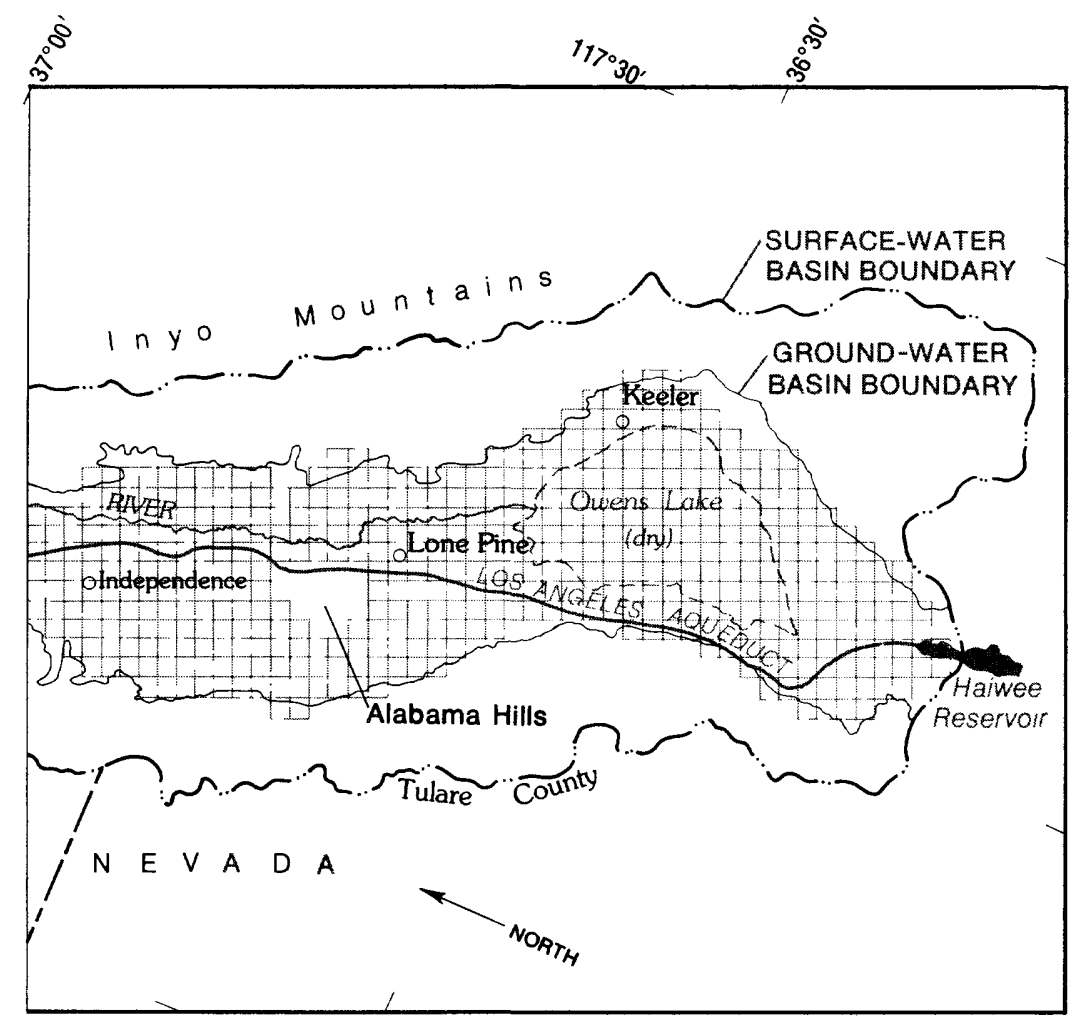

\section{EXPLANATION}

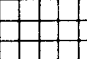

PERMEABLE MATERIAL

AREA OF SIMULATED UNDERFLOW

Minor differences between the edge of the finite-difference grid and the ground-water basin boundary can be attributed to differences between small-scale maps used to define the actual model area (M.L. Blevins, Los Angeles Department of Water and Power, written commun., 1984), and the large-scale map used to prepare this figure (Los Angeles Department of Water and Power, 1979, figure 5-1).

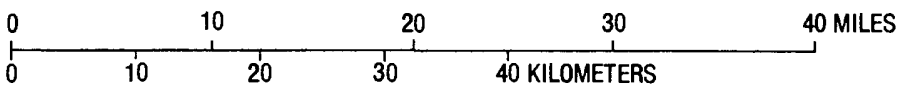

\section{Representation of the Ground-Water System}

Model Boundaries and Layers

Boundaries of the ground-water-flow model conform to the physical boundaries of the Owens Valley ground-water basin with four exceptions. First, underflow from Chalfant valley in the north was approximated using Darcy's Law. This key hydrologic relation, which also forms the basis of the mathematical ground-water model, relates the rate of ground-water flow to the cross-sectional area of flow, the hydraulic conductivity of the aquifer materials, and the hydraulic-head gradient. The quantity of underflow calculated using Darcy's law was distributed uniformly along the boundary and held fixed during the simulations (fig. 5). Both the location and method used to estimate underflow from Chalfant Valley are the same ones used by Los Angeles Department of Water and Power (1972, 1976). 
Second, investigators since C.H. Lee (1912) have speculated that underflow into the basin occurs through and under the Volcanic Tableland north of Bishop. However, no estimates of the magnitude of this suspected inflow have been made. For this modeling study, the Volcanic Tableland and any alluvium beneath it were simulated as no-flow boundaries on the assumption that any inflow would be negligible compared to the potential recharge from the nearby Owens River.

Third, as suggested by C.H. Lee (1912) and Los Angeles Department of Water and Power (1972), the Owens Valley ground-water system probably continues south beneath Haiwee Reservoir. These investigators estimated that a small quantity of underflow leaves the Owens Valley ground-water system. Los Angeles Department of Water and Power (1976) also noted that Haiwee Reservoir, which was not built when C.H. Lee conducted his studies, may have created a ground-water divide. If Haiwee Reservoir has created a ground-water divide, then no underflow can occur across the divide. However, recharge from the reservoir to ground-water systems on either side of the divide would be possible. In this study, Haiwee Reservoir was assumed to create a ground-water divide and to maintain a constant hydraulic head in the surrounding ground-water system. Simulation of a constant hydraulic head in the ground-water model involves holding the head for that model block constant and using Darcy's law to calculate the quantity of flow to or from the block. The direction and quantity of flow depends upon the hydraulic gradient from the constant head (Haiwee Reservoir) to nearby hydraulic heads in the groundwater system (adjacent model blocks) and the intervening transmissivities.

Fourth, only the most active part of the ground-water system was simulated. The actual physical bottom of the ground-water basin is granitic and metamorphic bedrock. The depth to this bedrock ranges from zero feet at the base of the mountains to between 3,000 and 8,000 feet below land surface in the center of the valley (Pakiser and others, 1964). However, most recharge and withdrawal of ground water occurs relatively near the land surface. Because of the horizontal layering typically found in alluvial deposits, the effects of these near-surface flows propagate horizontally much more than vertically, and the deeper parts of the basin tend to remain unaffected. The increasing compaction of aquifer materials with depth decreases the quantity of water that can be stored in or transmitted through the deeper materials. For practical purposes, there is an effective bottom of the ground-water-flow system, below which little ground-water movement occurs. In the center of the valley, this depth was arbitrarily selected as 1,000 feet, or about 1.5 times the depth of the deepest pumped well. Along the edges of the valley where the depth to bedrock is less than 1,000 feet, the physical bottom of the ground-water basin was used.

All other boundaries of the model were assumed to be impermeable and were simulated with no-flow boundary conditions. Several previous water budgets, for example Los Angeles Department of Water and Power (1972, 1976), have included a value of underflow from Round Valley. Because Round Valley was included explicitly as part of the ground-water model, no boundary condition or estimate of underflow was necessary between Round Valley and Owens Valley. 
As is typical in most alluvial basins, the ground-water system in Owens Valley is composed of many different sand and gravel layers with intervening layers of silt and clay. The areal extent of individual layers ranges from a few feet to several hundred feet. With the available lithologic information, derived primarily from well logs, no individual aquifers or extensive zones of more permeable material could be defined. However, differences in hydraulic heads of as much as 30 feet have been observed between shallow wells just intersecting the water table and deeper wells perforated more than 100 feet below land surface (compare figs. 4A and 4B). This difference most likely results from the combined effect of numerous individual clay layers that inhibit the vertical movement of ground water. Although no specific physical correlation could be made, two generalized zones were assumed to be present, separated at approximately 100 feet below the water table (about 100 feet below land surface in the middle of the valley). In some areas of the valley, such as the upper alluvial fans, no confining layers have been identified and the two zones were assumed to function as one.

The division of the ground-water basin into horizontal zones or model layers is somewhat arbitrary. However, the division appears to be hydrologically reasonable and permits simulation of the measured hydraulic-head data, which are generally for either shallow, water-table wells or deeper wells tapping a composite confined zone. In addition to simulating vertical hydraulic-head gradients, the use of two layers is consistent with the assumption that both unconfined and confined storage conditions are present in some parts of the valley.

Flow between the two model layers is simulated with a Darcian relation involving vertical hydraulic conductivity and the hydraulic gradient between the layers. As an aid in the computer program, McDonald and Harbaugh (1984) defined a term, vertical conductance $\left(T^{-1}\right)$, which in its simplest form is vertical hydraulic conductivity $(L / T)$ divided by the distance $(L)$ across which the vertical hydraulic gradient is measured. Multiplying vertical conductance $\left(T^{-1}\right)$ by the difference in hydraulic heads $(L)$ between the two layers and by the area $\left(L^{2}\right)$ of the model block yields the rate of ground-water flow $\left(L^{3} / T\right)$ from one layer to another.

McDonald and Harbaugh (1984) noted that several methods of calculating vertical conductance are possible depending on the characteristics of the particular study area and design of the ground-water model. In Owens Valley, vertical conductance is strongly dependent on the vertical hydraulic conductivity and thickness of any confining materials such as silt or clay that lie between the centers of the two model layers. For this reason, vertical conductance was calculated as the vertical hydraulic conductivity of less permeable materials divided by their total thickness. This approximation assumes that the more permeable materials do not significantly retard the vertical movement of ground water. A lower value of vertical conductance is associated with a lower value of vertical hydraulic conductivity for the confining material or a greater thickness of fine-grained materials. A lower value of vertical conductance results in lower rates of vertical ground-water flow and greater differences in hydraulic heads between the model layers. 
For the purposes of this study, the permeable and impermeable materials of Owens Valley and Round Valley were grouped into six categories, each with relatively uniform hydrogeologic characteristics (fig. 6). These categories were used to develop general hydrologic concepts of the ground-water system and to extrapolate available data to areas where information was scarce or absent. The categories also served as the basis for defining differences in vegetation which in turn were associated with differences in evapotranspiration rates. During sensitivity analysis of the ground-water model, the categories were used to selectively vary a group of model parameters.

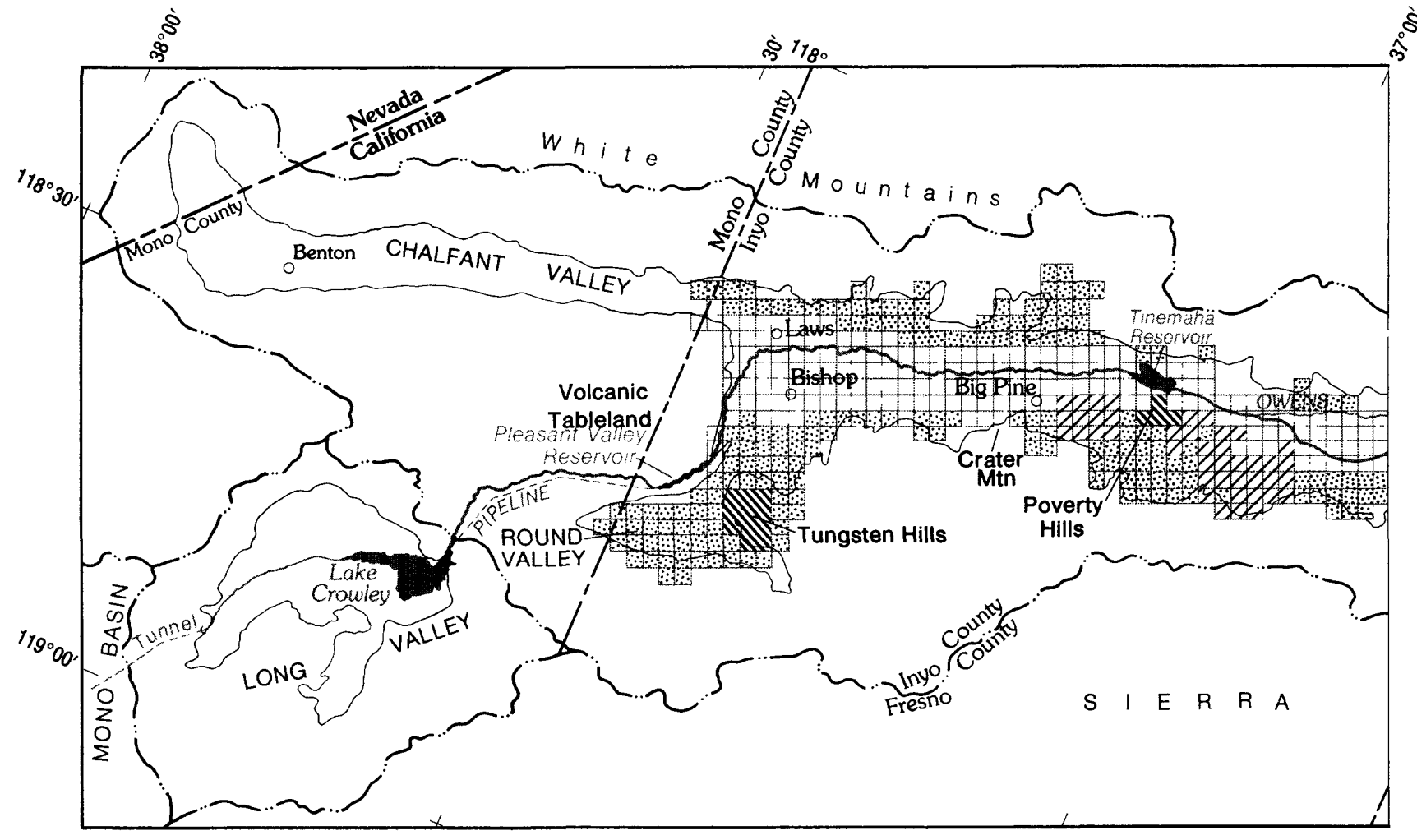

FIGURE 6. - Areas of the ground-water model with similar hydrogeologic characteristics. 
The six categories are: (1) alluvial fan deposits along the mountain fronts, (2) extensively faulted areas in alluvial fans north of the Alabama Hills, (3) stream-channel and deltaic deposits in the middle of the valley, (4) Takebed deposits covering the largest recent extent of Owens Lake, (5) permeable volcanic deposits near Tinemaha Reservoir, and (6) impermeable granitic and metamorphic rocks and volcanic materials. Dividing the entire valley into six groups required some generalizations. For example, the hydrogeologic characteristics of deposits in the middle of the valley do vary from north to south. However, in general, they are quite different from the hydrogeologic characteristics of materials in other categories.

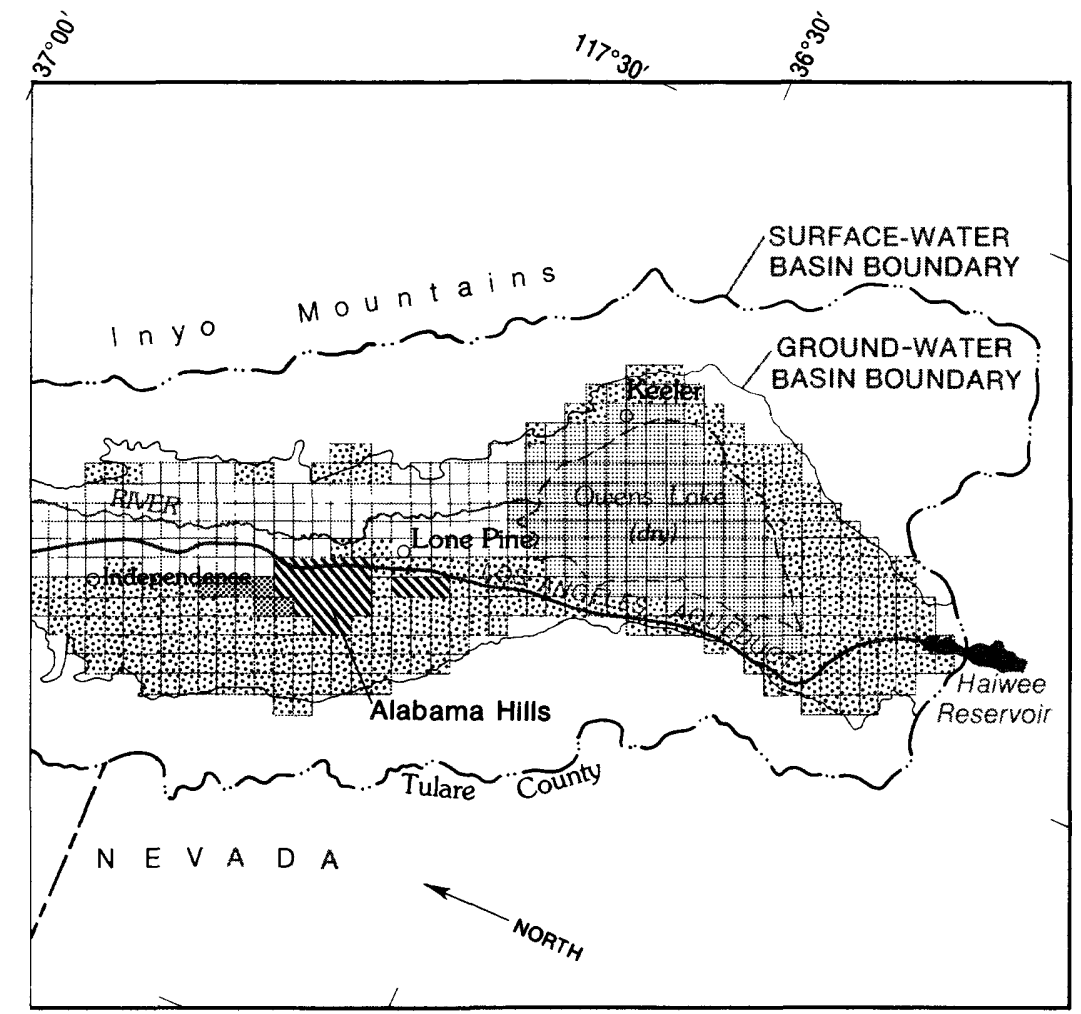

\section{EXPLANATION}

PERMEABLE MATERIALS

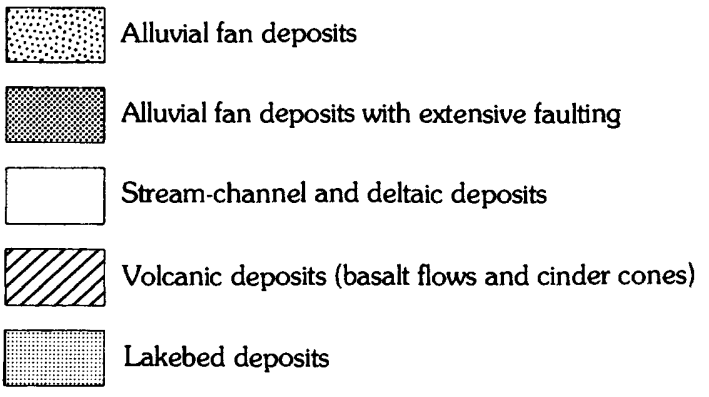

IMPERMEABLE MATERIALS

Granitic and metamorphic rocks

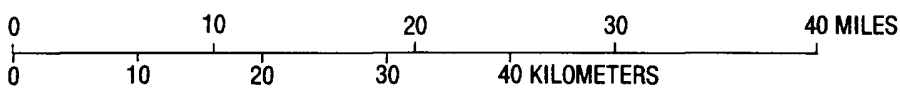


One of the most important aspects of the ground-water-flow model is the simulation of recharge to and discharge from the ground-water system. For this preliminary ground-water model, the standard methods of simulating recharge and discharge were used as described in the computer program documentation by McDonald and Harbaugh (1984). For a more detailed ground-water-flow model, other more sophisticated methods might be preferable. Some of these alternative methods are described briefly below and summarized in the section entitled, "Summary and Conclusions." The particular components of recharge and discharge that were included in the preliminary ground-water model are precipitation, evapotranspiration, stream recharge, well pumpage, flow across boundaries, and interaction with the Owens River, Los Angeles Aqueduct, and Tinemaha and Haiwee Reservoirs.

Precipitation and evapotranspiration were simulated using two slightly different approaches, depending on the area of the valley being considered. In upslope areas (alluvial fan and permeable volcanic deposits), the depth to ground water ranges from tens to many hundreds of feet. In these areas, vegetation was assumed to be unable to maintain root systems to the water table and therefore required to subsist on the quantity of water available from precipitation alone. During dry periods, all the precipitation would evaporate or would be used by plants. During wetter periods, precipitation would exceed evapotranspiration, and a small quantity of water would infiltrate to the ground-water system. Although the quantity of precipitation increases with altitude, the vegetative demand for water was assumed to increase in equal proportion. These assumptions result in a small, uniform quantity of infiltration from precipitation on the upslope areas.

In midvalley areas (stream-channel, deltaic, and lakebed deposits), the depth to ground water is much less than in the upslope areas. Although precipitation rates are low, the water table is usually within a few feet of the land surface. Root systems extend from land surface to the water table in most of these flat-lying areas. Vegetation is dominated by phreatophytes that were assumed to require more water than is generally available from the limited quantity of precipitation. Under these conditions, estimates of water use are typically based on the type of phreatophyte and the depth to the water table.

Whereas a single net infiltration value was used for the upslope areas, both precipitation and evapotranspiration for the midvalley areas were included explicitly in the ground-water model. Precipitation was estimated for each finite-difference block and then held fixed during calibration of the model. Because storms in Owens Valley are brief and the soil is usually dry, no surface runoff was assumed to occur in any part of the valley except from the surrounding mountains. Evapotranspiration in the midvalley areas was calculated as a linear function of depth to the water table. An assumption was made that evapotranspiration ceases when the water table is more than 15 feet below land surface. When the water table is at land surface, a maximum evapotranspiration rate is reached. At intermediate depths, the evapotranspiration rate linearly decreases from the maximum rate to zero. If 
precipitation at a particular location were to exceed calculated evapotranspiration, then the difference would represent a net recharge to the groundwater system. Similarly, in areas where the water table is less than 15 feet below land surface, if evapotranspiration were to exceed precipitation, then the difference would represent a net discharge from the ground-water system. Precipitation and evapotranspiration on bedrock areas within the ground-water system were assumed to balance each other or to produce a negligible quantity of recharge.

Although the linear relation used in this study to approximate evapotranspiration produces reasonable results, actual evapotranspiration is a much more complicated phenomenon. One of the objectives of the cooperative studies of Owens Valley by Inyo County, Los Angeles Department of Water and Power, and the U.S. Geological Survey is to develop an improved evapotranspiration function and a computational algorithm that can be included in future groundwater-flow models.

Stream recharge was calculated as a percentage of average stream inflow at the base of the mountains. Spatial distribution of this quantity was based on the percentage of the total stream length in an individual finitedifference block. Figure 7 shows the distribution of stream recharge throughout the model. In reality, the quantity of recharge also probably depends on the width of the stream channel, the type of streambed material, and the hydraulic gradient from the stream to the ground-water system. A computer program by D.E. Prudic (U.S. Geological Survey, oral commun., 1986) uses these characteristics for individual streams in order to calculate stream recharge rates within each finite-difference block. Use of this program in future modeling efforts might improve the simulation of stream recharge.

A11 pumpage was assumed to be withdrawn from the lower model layer (fig. 7A), which, in the vicinity of production wells, corresponds to depths greater than 100 feet. Most production wells are 300 to 500 feet deep with perforations predominantly in the deeper zones. Near-surface perforations or extensive gravel packing in production wells would cause a withdrawal of water from shallower zones, but this quantity was assumed to be relatively small. Development of a more detailed model will probably require simulating the withdrawal of even small quantities of water from an upper layer. A computer program by McDonald (1984) based on theory developed by Bennett and others (1982) automatically proportions the total discharge of a well to each of several layers depending on the length of perforations, the thickness of saturated material, and the horizontal hydraulic conductivity of each layer. If either total discharge or saturated thickness changes, the program recomputes the quantity of discharge from each layer. This program would be particularly helpful for more accurate simulation of ground-water conditions near well fields.

The location and method of approximating ground-water flow across model boundaries are discussed at length in the previous section entitled, "Model Boundaries and Layers." In summary, underflow from Chalfant Valley was calculated and proportioned to each model layer. With the exception of a ground-water divide beneath Haiwee Reservoir, all other model boundaries were assumed to be impermeable. 

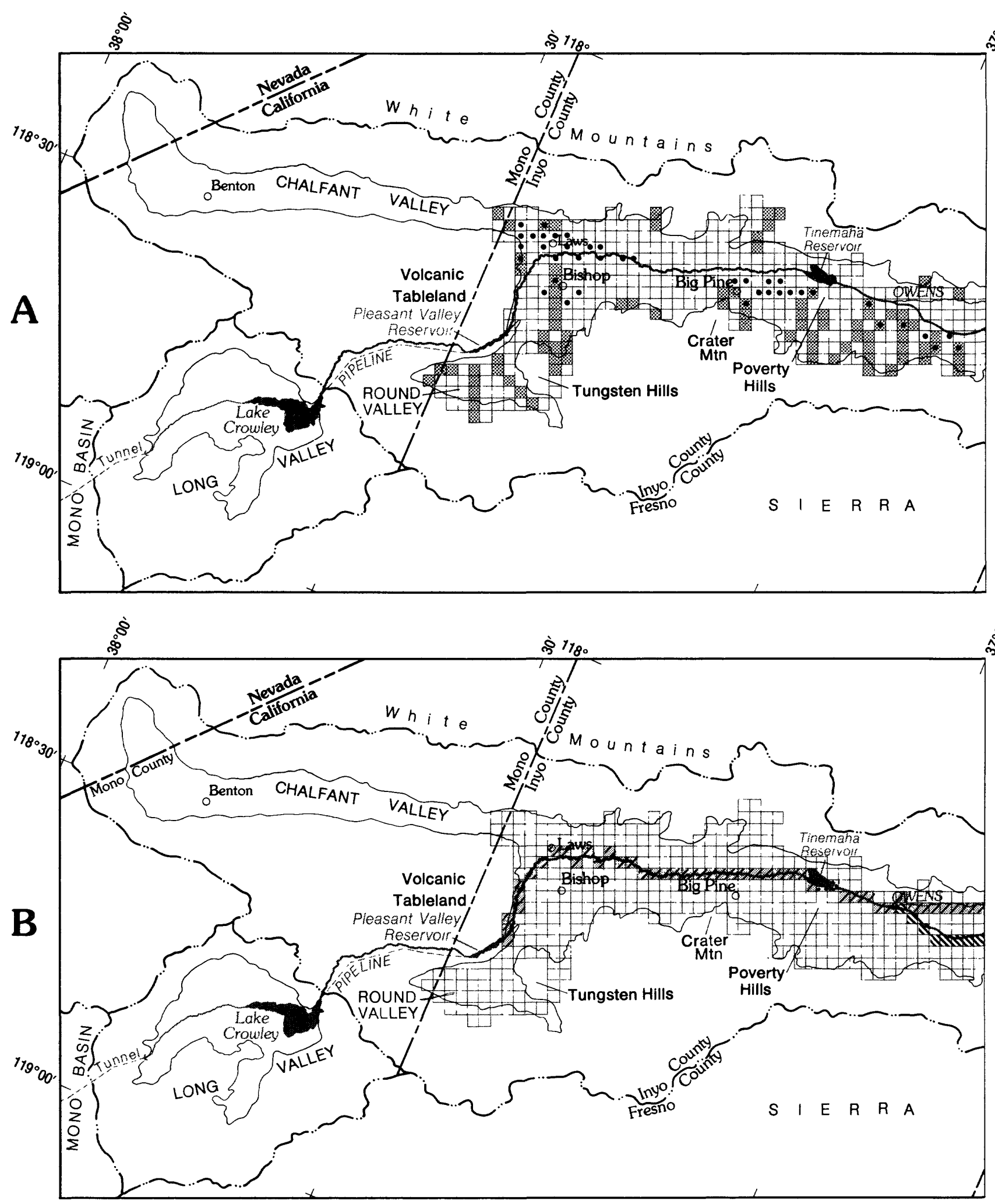

FIGURE 7. - Location of (A) simulated stream recharge and ground-water pumpage, and (B) constant-head conditions in the ground-water model. 

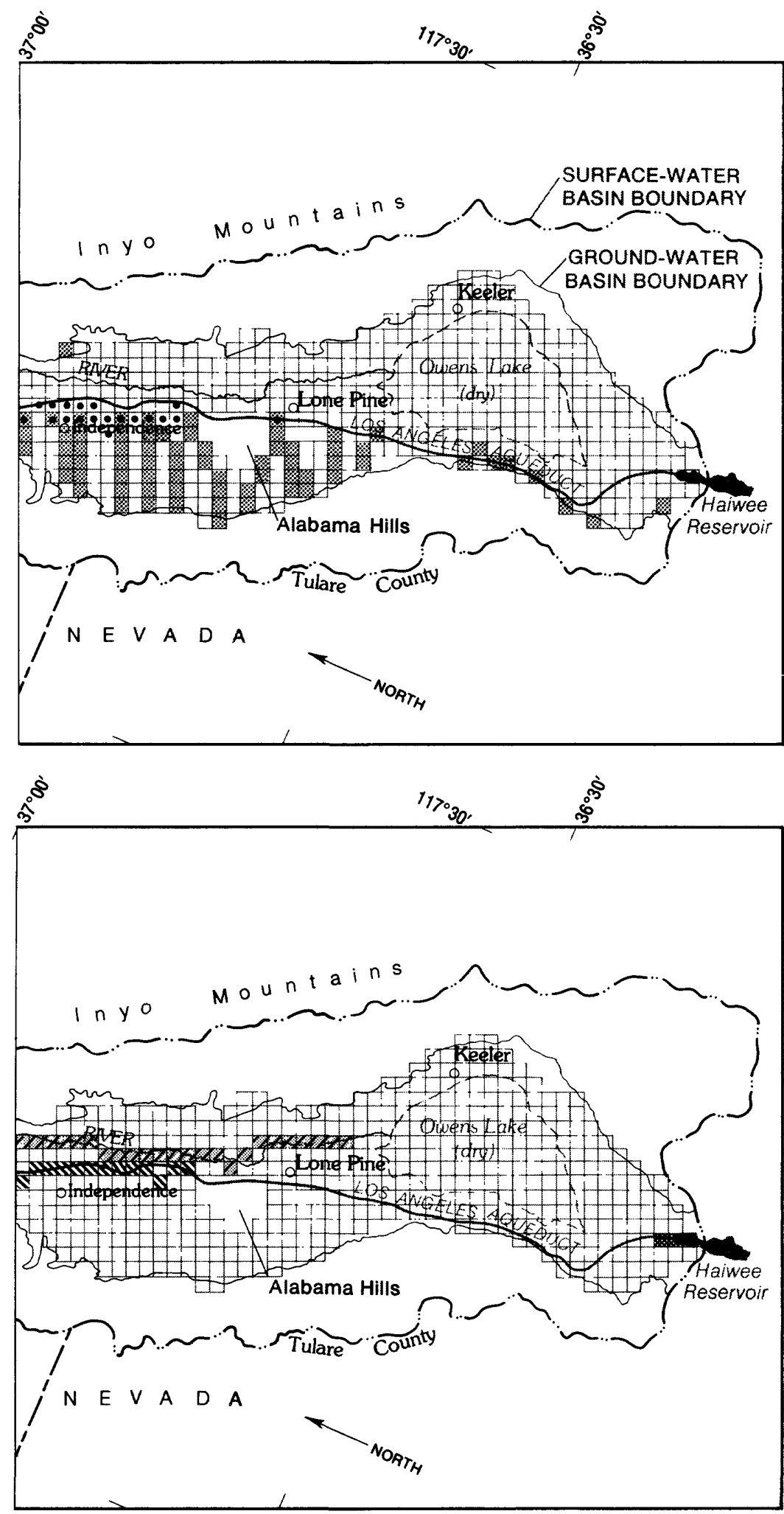

$\begin{array}{cccccc}0 & 10 & 20 & 30 & 40 \text { MILES } \\ 0 & 10 & 10 & 20 & 30 & 40 \text { KILOMETERS }\end{array}$

\section{EXPLANATION}

STREAM RECHARGE - Upper model layer

- GROUND-WATER PUMPAGE

- Lower model layer

\section{EXPLANATION}

CONSTANT-HEAD CONDITIONS

- Upper model layer

Owens River

Tinemaha Reservoir

Los Angeles Aqueduct

Haiwee Reservoir 
The Owens River, Los Angeles Aqueduct, and Tinemaha and Haiwee Reservoirs interact with the ground-water system in a different way than do the small streams along the sides of the valley. These four dominant surface-water features have been present for many years, each virtually always has had some water in it, and each is situated close to the ground-water table. Because of these characteristics, the surface-water bodies were assumed to be in direct hydraulic connection with the saturated ground-water system. In contrast to the deep percolation of recharge water that occurs from streams on the alluvial fans, a direct hydraulic connection enables water to be either recharged or discharged. The direction and quantity of flow is determined by the differences in hydraulic head between the aquifer and the reservoir and by the hydraulic characteristics of the intervening material. If the material is relatively permeable, then the hydraulic heads will be nearly the same. For the purposes of this study, the hydraulic head in the ground-water system was assumed to be the same as the hydraulic head of the nearby surface-water body. This relation is simulated in the ground-water model by using constant-head conditions for the upper model layer wherever it coincides with one of the dominant surface-water features (fig. 7B). An exception is the Los Angeles Aqueduct south of the Alabama Hills to Haiwee Reservoir. In this section, the aqueduct has a concrete liner and is elevated above the observed water table. Because concrete is relatively impermeable, any leakage that might occur through the concrete was assumed to be negligible.

A constant head in a numerical model functions in much the same way as an actual surface-water body does in the real world; both act as buffers to changes in hydraulic head in the ground-water system. If nearby hydraulic heads rise, ground-water flow to the surface-water body is increased, thereby reducing the tendency for hydraulic heads to rise further. If nearby hydraulic heads decline, flow is induced from the surface-water body to the ground-water system, thereby decreasing the rate of decline. Simulated hydraulic heads near a constant head are relatively insensitive to changes in the ground-water system, but the quantity of flow does vary. Therefore, accurate interpretation of model results near a constant head requires that the flow to and from the constant head be evaluated more carefully than nearby hydraulic heads.

Future modeling of the ground-water system might benefit from a more detailed simulation of the interaction between the major surface-water bodies and the ground-water system. A variety of physically based relations are available that incorporate the wetted surface area of the interface, the hydraulic conductivity of intervening materials, and temporal variability in the hydraulic head of the surface-water body (for example, McDonald and Harbaugh, 1984; D.E. Prudic, U.S. Geological Survey, written commun., 1986; Durbin and others, 1978). Although use of these methods may yield more accurate results, particularly in transient analyses, using them requires a greater number of model parameters, most of which are unknown and must be estimated. 


\title{
Simulation of Equilibrium Conditions
}

\author{
Period of Simulation
}

The period of water years 1935-70 was chosen to simulate the ground-water system under equilibrium conditions. This particular period was chosen for three reasons. First, ground-water levels did not appear to change significantly between 1935 and 1970, a necessary prerequisite for a steady-state analysis. Second, contoured hydraulic-head maps for 1970 were available for the entire valley. Third, water-budget information had been summarized for similar periods, water years 1935-69 (Los Angeles Department of Water and Power, 1972) and water years 1936-66 (Los Angeles Department of Water and Power, 1976). Although it would have been preferable to use a steady-state period after the onset of increased ground-water pumping in 1970, water-budget and hydraulic-head data were insufficient to determine if another steady-state period occurred after 1970.

Simulation of water years 1935-70 required the use of some approximations. Los Angeles Department of Water and Power (1972) showed that the valleywide system was in equilibrium for water years 1935-69. Because hydrologic management practices and the use of ground water during this period were virtually constant, the ground-water system was also assumed to be in equilibrium. As noted by Los Angeles Department of Water and Power (1976), the valleywide equilibrium was undoubtedly affected by unusually high precipitation and streamflow in 1969. However, the wet conditions in 1969 were assumed to be offset by drier conditions in 1970 so that ground-water levels by late 1970 were fairly representative of the pre-1970 ground-water system.

The hydraulic heads that had been plotted for 1970 were only for a composite deep zone. Hydraulic-head data for shallow zones were unavailable until 1974 when shallow observation wells were drilled. To calibrate both layers of the preliminary ground-water model, it was necessary to use deep hydraulic heads from 1970 (fig. 4B) and shallow hydraulic heads from 1974 (fig. 4A). Although hydraulic heads for the shallow zone may have been slightly different in 1970, this approach was assumed to be sufficiently accurate to develop general impressions of the hydrologic system of the valley and to guide the development of more sophisticated ground-water models. Most of the increases in ground-water pumpage after 1970 were from the deeper zones in the valley. Although the pumpage may have affected shallow hydraulic heads, the assumption was made that it did not alter the direction and magnitude of ground-water flow. In future modeling efforts, the use of hydraulic-head data that are consistent with the period of the water budget probably would provide more accurate results from the ground-water model. 
Model Calibration

Calibration of the ground-water model involved a trial-and-error adjustment of model parameters representing aquifer characteristics and certain inflows and outflows in order to obtain an acceptable match between measured and computed hydraulic heads. The calibration process was continued until further changes in the ground-water model did not significantly improve the results and until the model parameters, inflows and outflows, and computed hydraulic heads were within the uncertainty of historical data.

During calibration, the location and type of model boundaries were assumed to be known and were not varied. Model parameters (transmissivity and vertical conductance) were adjusted for each hydrogeologic area. Initial and calibrated values of the parameters for each hydrogeologic category are shown in table 1. Transmissivity values were adjusted within the general range indicated by previous studies. In the areas of lakebed deposits and alluvial fan deposits with extensive faulting, no prior estimates were available and calibrated values were obtained by matching measured hydraulic heads and estimated flow rates. Calibrated values of transmissivity were slightly higher than initial estimates for lakebed deposits, and slightly lower than initial estimates for stream-channel, deltaic, and permeable volcanic deposits.

Values of vertical conductance were not constrained during calibration because no estimates were available for any area of the valley. Instead, values were adjusted until simulated hydraulic heads in the upper and lower model layers matched the hydraulic heads indicated by contour maps of measured hydraulic heads (fig. 4). For most of the area covered by alluvial fan deposits, measured hydraulic heads were not available. In these areas, values of vertical conductance were adjusted so that simulated hydraulic heads in the two layers differed by less than 1 foot. In these areas, actual values of vertical conductance may be higher than the calibrated ones, but probably are not lower.

Initial values of inflow and outflow to the ground-water system were estimated for the steady-state period using data from the section entitled, "Water Budget." Calibration of the ground-water model involved adjusting some of the initial estimates in order to assure a balance of inflow and outflow as well as to match the distribution of measured hydraulic heads. Calibrated values for the major components of inflow and outflow are summarized in table 2. Because prior estimates of inflow and outflow were calculated for different areas of the valley and for different time periods, some deviation between published and calibrated values should be expected even when the same data and assumptions are used. The method of calibrating each component of inflow and outflow is described below along with any significant differences between prior estimates and calibrated values. 
Table 1.--Initial and calibrated values of model parameters for different hydrogeologic categories

\begin{tabular}{|c|c|c|c|c|c|c|}
\hline \multirow{4}{*}{$\begin{array}{l}\text { Hydrogeologic } \\
\text { category }\end{array}$} & \multicolumn{4}{|c|}{$\begin{array}{c}\text { Transmissivity, in feet } \\
\text { squared per day }\end{array}$} & \multirow{2}{*}{\multicolumn{2}{|c|}{$\begin{array}{c}\text { Vertical } \\
\text { conductance } \\
\text { per day }\end{array}$}} \\
\hline & \multicolumn{2}{|c|}{ Initial } & \multicolumn{2}{|c|}{ Calibrated } & & \\
\hline & Upper & Lower & Upper & Lower & & \\
\hline & layer & layer & layer & layer & Initial & Calibrated \\
\hline Alluvial fan deposits & 1,300 & 1,300 & 540 & 1,300 & 0.1 & 0.01 \\
\hline Alluvial fan deposits with faults & 130 & 130 & 270 & 670 & 0.1 & 0.01 \\
\hline Stream-channel and deltaic deposits & 4,000 & 40,000 & 2,100 & 21,000 & 0.01 & 0.0006 \\
\hline Lakebed deposits & 800 & 8,000 & 1,300 & 13,000 & 0.002 & 0.0004 \\
\hline Permeable volcanic deposits & 13,000 & 130,000 & 3,300 & 33,000 & 0.01 & 0.002 \\
\hline
\end{tabular}

Table 2.--Simulated steady-state budget for water years 1935-701 [+ indicates net inflow; - indicates net outflow]

\begin{tabular}{|c|c|c|c|}
\hline $\begin{array}{l}\text { Water-budget } \\
\text { components }\end{array}$ & $\begin{array}{l}\text { Inflow, } \\
\text { in acre- } \\
\text { feet }\end{array}$ & $\begin{array}{l}\text { Outflow, } \\
\text { in acre- } \\
\text { feet }\end{array}$ & $\begin{array}{l}\text { Total, } \\
\text { in acre- } \\
\text { feet }\end{array}$ \\
\hline Precipitation 2 & 297,354 & $\ldots$ & $+297,354$ \\
\hline Stream recharge & 82,293 & -- & $+82,293$ \\
\hline Boundary underflow & 10,859 & -- & $+10,859$ \\
\hline $\begin{array}{l}\text { Evapotranspiration: }{ }^{2} \\
\text { Alluvial fan and volcanic } \\
\text { deposits } \\
\text { Stream-channel, deltaic, and } \\
\text { lakebed deposits } \\
\text { Subtotal }\end{array}$ & -- & $\begin{array}{l}183,084 \\
144,778 \\
327,862\end{array}$ & $\begin{array}{r}-- \\
-327,862\end{array}$ \\
\hline Ground-water pumpage & -- & 19,743 & $-19,743$ \\
\hline $\begin{array}{l}\text { Owens River, Los Angeles } \\
\text { Aqueduct, Tinemaha and } \\
\text { Haiwee Reservoirs }\end{array}$ & 35,836 & 78,666 & $-42,829$ \\
\hline $\begin{array}{c}\text { Numerical error } \\
\text { Total }\end{array}$ & 426,344 & $\begin{array}{r}3 \\
426,271\end{array}$ & $\begin{array}{r}-3 \\
+72\end{array}$ \\
\hline
\end{tabular}

ISimulated values should be considered accurate to no more than two significant figures. Additional precision is shown for computational purposes only.

2 Values are totals for the hydrologic system, not simply recharge to or discharge from the ground-water system. 
A map of average precipitation throughout the valley for water years 1935-69 (Los Angeles Department of Water and Power, 1972, plate II-D) was used to develop values for the model. Values were interpolated from the map for each finite-difference block and then held fixed during model calibration. The total quantity of average precipitation estimated to fall on the model area, excluding the three bedrock areas within the ground-water basin, was 297,000 acre-ft/yr. A previous study by Los Angeles Department of Water and Power (1972) using the same map estimated that total precipitation over the ground-water basin was 343,000 acre-ft/yr. Los Angeles Department of Water and Power included the three bedrock areas in the estimate, but excluded Round Valley. The 15-percent difference in the two estimates is indicative of the differences that can be expected even when using the same information.

Evapotranspiration was simulated differently for upslope areas of the valley where the water table is deep than for midvalley areas where the water table is shallow. Because the five hydrogeologic categories of permeable deposits (fig. 6) correspond well to either upslope or midvalley areas, the hydrogeologic categories also were used in calibrating evapotranspiration. Upslope areas were defined as alluvial fans, fault zones on the fans, and volcanic deposits. Midvalley areas were defined as stream-channel, deltaic, and lakebed deposits.

In the upslope areas, a net infiltration rate was used to simulate the combined effects of precipitation and evapotranspiration. Nearly all precipitation was assumed either to evaporate or to be captured and transpired by vegetation. Therefore, a low net infiltration rate of $0.1 \mathrm{in} / \mathrm{yr}$ was chosen initially and was not changed during calibration. Virtually no information is available on the quantity of infiltration in the upslope areas because of the rocky material and great depth to ground water. With limited data, C.H. Lee (1912) estimated that 16 percent of precipitation on alluvial fans would percolate to the ground-water system, or a net infiltration rate of approximately 1 to $2 \mathrm{in} / \mathrm{yr}$. However, C.H. Lee's estimate may be too high because it was based on observations of soil moisture after an unusually large quantity of rain (3.5 inches) fell in only a few days. Water budgets reported by Los Angeles Department of Water and Power $(1972,1976)$ were developed using assumptions based on C.H. Lee's estimate and, thus, indicate substantially greater quantities of infiltration in the upslope areas than were used in this model.

In the midvalley areas, a depth-dependent function was used to simulate evapotranspiration. The function is described in a previous section entitled, "Methods of Simulating Aquifer Recharge and Discharge." Calibration of the ground-water model involved adjusting two parameters of the function--the maximum evapotranspiration rate and the depth at which evapotranspiration decreases to zero. The initial and calibrated values of the maximum evapotranspiration rate are shown in table 3 . Initial values of the maximum evapotranspiration rate were derived from estimates made by D.P. Groeneveld (Inyo County Water Dept., written commun., 1984). A broad range of maximum rates was considered during calibration because of the wide variation in estimates of average evapotranspiration made by different investigators, for example, 5 to $13 \mathrm{in} / \mathrm{yr}$ by D.P. Groeneveld (Inyo County Water Dept., written commun., 1984), 22 to $28 \mathrm{in} / \mathrm{yr}$ by C.H. Lee (1912), $30 \mathrm{in} / \mathrm{yr}$ by California Department of Water Resources (1960, p. 45), and 31.2 in/yr by D.E. Williams (1969). Although the maximum evapotranspiration rate probably varies over 
Table 3.-- Initial and calibrated maximum evapotranspiration rates

for different hydrogeologic categories

Hydrogeologic category
Maximum evapotranspiration rate, in inches per year ${ }^{3}$
Alluvial fan deposits

Alluvial fan deposits with faults Stream-channe 1 and deltaic deposits Lakebed deposits

Permeable volcanic deposits
Initial

Calibrated

\footnotetext{
${ }^{1}$ In the upslope areas, a net infiltration rate (net) of $0.1 \mathrm{in} / \mathrm{yr}$ was used rather than the depth-dependent evapotranspiration function. Net infiltration equals precipitation minus evapotranspiration.
}

small distances, the most significant differences were assumed to occur between areas represented by different hydrogeologic categories. During calibration, the maximum evapotranspiration rate in these areas was adjusted uniformly. The depth of zero evapotranspiration was assumed to be controlled by the depth of rooting. In many areas of the valley, roots have been observed within 10 feet of the land surface (D.P. Groeneve1d, Inyo County Water Dept., oral commun., 1984); therefore, 10 feet was initially assumed to be the depth of zero evapotranspiration. During calibration the depth was increased to 15 feet in order to obtain a numerically stable solution. This requirement may indicate that the model grid is too coarse to simulate the abrupt changes in depth to water and the related evapotranspiration rates that are present near the toes of the alluvial fans.

Evapotranspiration from both upslope and midvalley areas totaled 328,000 acre-ft/yr (table 2). Additional evapotranspiration occurs from areas simulated with constant-head blocks. Although this value was not calculated directly by the mode1, it may total as much as 79,000 acre-ft/yr, the quantity of outflow from the area simulated with constant-head blocks. If this were the case, then total evapotranspiration from the model area would equal approximately 407,000 acre-ft/yr. Using a slightly different area and somewhat different assumptions, Los Angeles Department of Water and Power (1976) estimated that total evapotranspiration from Owens Valley averaged 594,000 acre-ft/yr. California Department of Water Resources (1960) estimated that evapotranspiration from high ground-water areas averaged 250,000 acre-ft/yr. This estimate can be compared to the simulated evapotranspiration from midvalley areas $(145,000$ acre-ft/yr plus as much as 79,000 acre-ft/yr). The difference between previous estimates of evapotranspiration and simulated values is greater than for any other item in the water budget. However, both the estimates and simulated values were calculated as water-budget residuals. The true disparity, therefore, lies with the assumptions made in determining the nonresidual terms, in particular stream recharge. 
Recharge for individual streams was varied during calibration between 35 and 60 percent of measured streamflow at the base of the mountains. A long-term, average value of streamflow for each major stream was obtained from W.F. Hardt (U.S. Geological Survey, written commun., 1984). The range of recharge rates was chosen on the basis of recharge studies on 13 streams conducted by C.H. Lee (1912). Initially, a recharge rate of 60 percent was assumed for each stream except Bishop and Big Pine Creeks. Because of the significantly greater quantity of flow in these streams, lower rates of 20 and 40 percent, respectively, were assumed. During calibration the recharge rates were reduced to 15 and 20 percent for Bishop and Big Pine Creeks, respectively, and to an average of 42 percent for all other streams. For a few small, ephemeral streams on the eastern side of the valley, the quantity of streamflow was estimated using gaged values of flow in nearby streams and the relative size of drainage areas. Based on the assumption that nearly all flow in the ephemeral streams percolates to the ground-water system, a recharge rate of 90 percent was chosen initially and not altered during calibration. Additional recharge probably also occurs from small streams in ungaged areas along the western side of the valley; however, the quantity of this recharge was assumed to be much less than recharge from gaged streams and was not included in the ground-water model.

After calibration, total recharge from streamflow within the model area was 82,000 acre-ft/yr. For a similar period of time and an area that excluded Round Valley, Los Angeles Department of Water and Power (1976) estimated a value of 192,000 acre-ft/yr for a combination of recharge from streamflow and recharge from diversions of streamflow for various uses, such as agriculture. This difference in total stream recharge is the most notable discrepancy between prior estimates and calibrated model values. The deviation results from the model having lower recharge rates for individual streams, no recharge in ungaged areas, and no recharge from diversions, particularly in the area near Bishop and Laws.

Ground-water pumpage was estimated for water years 1935-70 from Los Angeles Department of Water and Power records. Only large production wells maintained by Los Angeles Department of Water and Power or abandoned flowing wells monitored by Los Angeles Department of Water and Power were considered. Although some agricultural, municipal, or domestic pumpage undoubtedly occurred, the quantity was assumed to cause negligible effects on the ground-water system at the scale of this study. Records maintained for each production well were used to estimate average pumpage for the steady-state period. Estimates of average discharge from flowing wells were based on the quantity of flow observed in water years 1936 and 1940 , years of average precipitation. The total pumpage from production and flowing wells was estimated for the steady-state period to be 19,700 acre-ft/yr. This value was held constant during model calibration. For a similar period, water years 1935-69, Los Angeles Department of Water and Power (1972) estimated a total pumpage of 10,600 acre-ft/yr. The difference in the two values probably results from different assumptions or averaging techniques for the flowing wells.

Underflow into the model area was assumed to occur only from Chalfant Valley. Average long-term inflow from this area was estimated by Los Angeles Department of Water and Power (1976) to be 10,800 acre-ft/yr. This value was used directly in the model and was not adjusted during calibration. All other 
boundaries were assumed to be impermeable except for the ground-water divide assumed to be present beneath Haiwee Reservoir. The difference between previous estimates of flow across boundaries (Los Angeles Department of Water and Power, 1972, 1976) and simulated values of underflow results from a different concept of the boundary condition at Haiwee Reservoir and the inclusion of Round Valley in the simulated model area.

Interaction of the ground-water system with the Owens River, the Los Angeles Aqueduct, and Tinemaha and Haiwee Reservoirs was calculated automatically by the ground-water model. The quantity of simulated inflow or outflow for a model block depends on a defined constant hydraulic head for the block, model parameters in adjacent model blocks, and nearby inflows and outflows. As model parameters and other inflows and outflows are adjusted during calibration, the quantity of flow into and out of constant-head blocks will change. Calibration of the model involved observing the constant-head flows and adjusting other parts of the model in order to simulate the observed pattern and average rates of inflow and outflow for the river, aqueduct, and reservoirs.

The total inflow and outflow from areas simulated with constant-head conditions are 36,000 acre-ft/yr and 79,000 acre-ft/yr, respectively. The total inflow represents a loss of water from the river, aqueduct, and reservoirs. Los Angeles Department of Water and Power (1972) estimated that the river and aqueduct south of Tinemaha Reservoir lost an average of 25,000 acre-ft/yr. Los Angeles Department of Water and Power (1976) revised this estimate to 9,400 acre-ft/yr, excluding any losses in the Owens River after it is diverted. Losses near Haiwee Reservoir have been estimated by Los Angeles Department of Water and Power (1972) to be 11,000 acre-ft/yr. Thus, the general range of estimated inflow is between 9,400 acre-ft/yr and 36,000 acre-ft/yr, or approximately the same as the simulated values. The total outflow represents a discharge from the ground-water system or a gain of water in the river, aqueduct, and reservoirs. An important part of the total outflow would likely be evapotranspiration within the 65,280 acres of constant-head blocks. As described earlier, the ground-water model does not explicitly calculate evapotranspiration for these areas; however, an average evapotranspiration rate of $12 \mathrm{in} / \mathrm{yr}$ would equal 65,280 acre-ft/yr. Additional outflow is represented by gains in the Owens River, particularly in the Bishop area. Los Angeles Department of Water and Power (1976) estimated that the Owens River gained an average of 6,600 acre-ft/yr to 9,400 acre-ft/yr between Pleasant Valley and Tinemaha Reservoirs. The estimated and calibrated total outflow also appear to be in close agreement. Estimates of surface-water gains and losses, however, are subject to large relative errors.

Overall results of calibration of the model for the steady-state period are shown in figures 8 and 9 . Figure 8 shows the match between measured and simulated hydraulic heads for each model layer. Measured hydraulic head for each finite-difference block was obtained by interpolating values from contour maps of hydraulic heads developed for 1974 (upper layer) and 1970 (lower layer) by Los Angeles Department of Water and Power (1976). In many areas of the valley, hydraulic-head measurements either were unavailable or could not be reliably inferred. Areas with particularly poor data include the upper reaches of the alluvial fans and areas east of the Owens River. During calibration, areas with reliable hydraulic-head data were weighted more heavily than areas with estimated hydraulic heads. For the purposes of this 

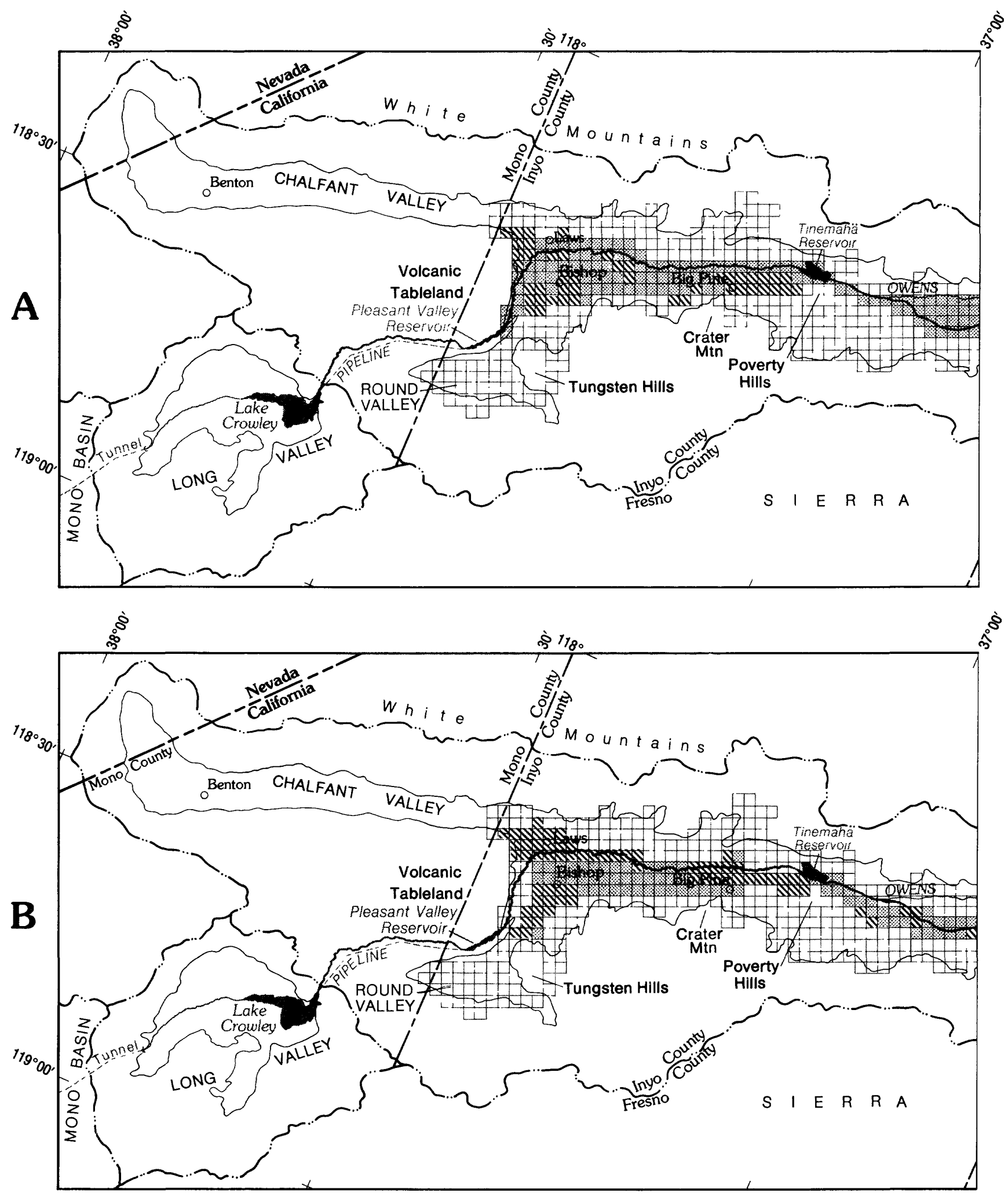

FIGURE 8. - Comparison of simulated and measured hydraulic heads for (A) the upper layer and (B) the lower layer of the ground-water model. (Only those areas with reliably known hydraulic heads were considered in the comparison.) 
study, an unsatisfactory match between simulated and measured hydraulic heads was defined as greater than a 15-foot difference. Areas where the match between simulated and measured hydraulic heads was unsatisfactory are (1) along the toes of alluvial fans, (2) near Big Pine where the permeable volcanic deposits meet the stream-channel and deltaic deposits, (3) northeast of Bishop near Laws, and (4) near Bishop and Lone Pine Creeks.

Figure 9 is a similar map showing areas of satisfactory and unsatisfactory agreement between simulated and estimated inflows to and outflows from the Owens River, Los Angeles Aqueduct, and Tinemaha and Haiwee Reservoirs. The method of simulating these flows (constant-head conditions) exerts a strong control in the ground-water model. Because the hydraulic head in these locations is defined, it is the flow rate that varies during model calibration. Unsatisfactory agreement in rates of flow indicate areas where calibration is in need of improvement, just as do differences between simulated and measured hydraulic heads. Because local recharge and discharge

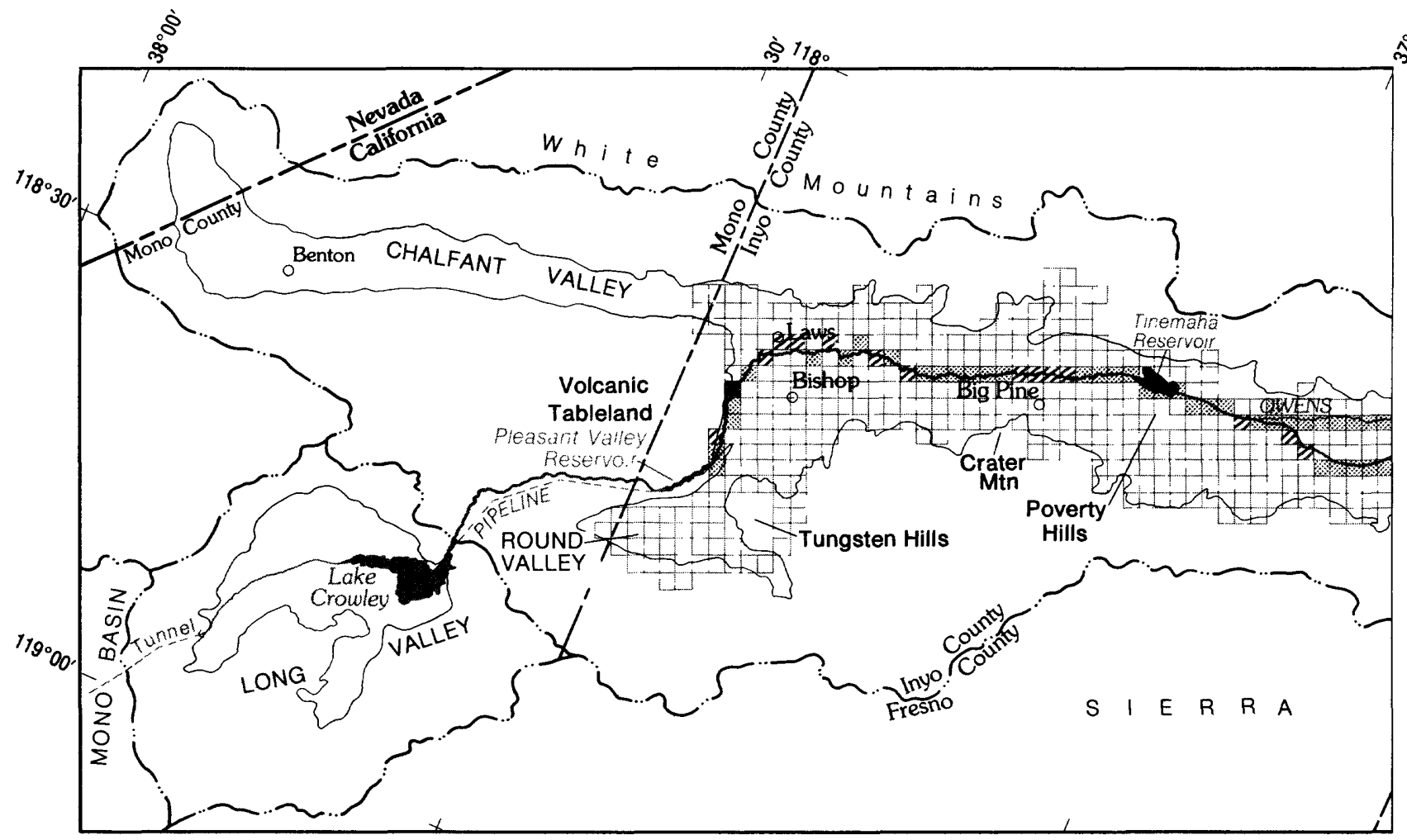

FIGURE 9. - Comparison of simulated and estimated rates of recharge and discharge for the Owens River, the Los Angeles Aqueduct, and Tinemaha and Haiwee Reservoirs. 
Sensitivity Analysis

Sensitivity analysis is a procedure to determine how sensitive the model solution is to changes in each input variable, including transmissivity, inflow and outflow rates, and storage coefficients. As is always the case with numerical models, not all the variables of the preliminary model were known completely. Because some uncertainty is found in each input variable, there is some uncertainty in the model solution. This uncertainty is reflected in hydraulic heads and inflow and outflow rates that are somewhat in error. A sensitivity analysis determines which input variables exert the most control over the model solution and, therefore, generate the largest errors. An improved understanding of the most sensitive variables would yield the greatest improvement in the ground-water model.

For the anaiysis, each of the input variables of the ground-water model was altered by a certain amount from the calibrated value used in the steady-state simulation. The amount of the alteration was determined by estimates of the likely range of the data. To simplify the analysis, variables for an entire hydrogeologic category, such as transmissivity on the alluvial fans, were altered together. Those variables associated with the most change in the model solution were identified as the most sensitive.

Although useful, this method of testing sensitivity is subject to a potentially significant flaw. Because each variable in the model is tested separately, the additive effects of changes in more than one variable are not considered. For example, the simultaneous overestimation of both recharge and evapotranspiration in the model would tend to be self-correcting. However, overestimating recharge and underestimating evapotranspiration would produce a considerably different model solution. If neither recharge nor evapotranspiration were by itself a sensitive part of the model, the conclusion from a routine sensitivity analysis would be that additional data for these items are unnecessary. Nevertheless, the additive effects of errors in recharge and evapotranspiration might produce significantly erroneous results in some simulations of the ground-water system. An important way to prevent this type of miscalculation is through a more subjective analysis of sensitivity observed during calibration of the ground-water model. For this reason, observations from the calibration process are also included in the following discussion of the sensitivity of each variable.

The areal distribution of transmissivity in the valley is based on scattered data and an assumption of uniformity within each area represented by the five categories of permeable deposits. Errors can be associated with the values of transmissivity chosen for an individual area and with the choice of area boundaries. The sensitivity of the model to the locations of the area boundaries is best evaluated by altering the locations, recalibrating the model, and observing the differences. However, this time-consuming process was not a part of this preliminary investigation. Sensitivity analysis was limited to varying the values of transmissivity for both model layers within an individual area and holding values in all other areas constant. The results of the analysis indicate that changes in transmissivity values have a considerable effect at boundaries with adjoining hydrogeologic areas, particularly along boundaries where alluvial fans and volcanic flows meet stream-channel and deltaic deposits. Definition of additional, smaller 
hydrogeologic areas may be required to successfully simulate ground-water flow in these locations of the valley. Local effects were observed due to changes in transmissivity near Owens Lake; however, none of the effects propagated very far north in the valley. If critical ground-water-management issues do not involve the area surrounding owens Lake, then a better understanding of transmissivity in that area is less important than in most other areas of the valley.

Values of vertical conductance between the two model layers were determined by calibration of the ground-water model because no estimates of vertical hydraulic conductivity were available. To test a wide range of possible values, vertical conductance in each hydrogeologic area was varied by two orders of magnitude. However, the effect on simulated hydraulic heads was not as pronounced as was expected. In fact, the model appeared to be rather insensitive to changes in vertical conductance. The apparent insensitivity could be deceptive, however, because a steady-state simulation was used to test the sensitivity, and vertical conductance is typically more important in transient simulations. For this reason, considerably more confidence could be placed on model results if estimates of vertical hydraulic conductivity also were made from field data.

Storage coefficients are a required part of a ground-water model used for transient analysis. Because the preliminary model was calibrated only for steady-state conditions, storage coefficients were not part of the calibration procedure and were not tested for sensitivity. However, another investigation of the southern part of Owens Valley using a ground-water-flow model determined that the storage coefficient is one of the least sensitive variables (Yen, 1985). Other findings by Yen are discussed later in a separate section of this report.

Precipitation records for Owens Valley are in general very good, except for an absence of precipitation stations on the eastern side of the valley. For the sensitivity analysis, an error of 20 percent was assumed in the measurement of precipitation. The effects of this error appear as both a slight change in hydraulic heads and a slight increase in the quantity of evapotranspiration. The most significant effects result from varying estimates of precipitation on the upper slopes of the alluvial fans where precipitation rates are high. Errors in estimating precipitation in these areas lead to substantially different estimates of evapotranspiration and, depending on the assumption of net infiltration, may lead to substantially different quantities of recharge to the valley.

Evapotranspiration data are sparse, even in the most intensively studied parts of the valley. Given this lack of information, variations of as much as 100 percent were investigated during the sensitivity analysis. Not surprisingly, variations in evapotranspiration produce the greatest variations in hydraulic heads, inflows, and outflows of any variable in the ground-water model. This is due primarily to the large role that evapotranspiration plays in the water budget and its broad areal distribution. The largest effect on simulations resulted from varying the quantity of net infiltration assumed to occur on the alluvial fan and volcanic deposits. Because these deposits cover a large area, a small change in the net infiltration rate results in a large change in the quantity of recharge to the ground-water system. Increasing the net infiltration rate caused dramatic changes near the boundaries between the 
alluvial fan and volcanic deposits and the stream-channel and deltaic deposits. In particular, hydraulic heads in both model layers increased, evapotranspiration rates increased, and the Owens River and the Los Angeles Aqueduct gained a large quantity of water when they were near the boundary between deposits. During one phase of calibration, a uniform evapotranspiration rate of $6 \mathrm{in} / \mathrm{yr}$ was assumed for the alluvial fan and volcanic deposits instead of a net infiltration rate. This formulation yielded a significantly greater quantity of recharge to the ground-water system. However, the model became numerically unstable and could not be calibrated using reasonable values for other model variables. The depth-dependent function used to simulate evapotranspiration in midvalley areas was less sensitive than the net infiltration rate. Variations in the maximum evapotranspiration rate of as much as 25 percent produced similar model results, except near boundaries of hydrogeologic areas. However, decreasing the maximum rate below $12 \mathrm{in} / \mathrm{yr}$ or increasing it above $36 \mathrm{in} / \mathrm{yr}$ produced unrealistic rates of recharge to or discharge from the river and aqueduct.

Measurements of streamflow are among the most complete and accurate hydrologic measurements in the valley. Because streamflow is measured at the head and mouth of most streams, estimates of stream recharge do not vary greatly, generally less than 15 percent. Sensitivity analysis using variations in this range showed that stream recharge is not a particularly sensitive part of the ground-water model. The most noticeable effects occurred near the toes of alluvial fans. However, the large discrepancy between prior estimates of stream recharge and calibrated values is much greater than 15 percent. When greater quantities of stream recharge were used during model calibration, the model solution degenerated in the same manner as when net infiltration was replaced with a fixed evapotranspiration rate. The likely cause of this problem is the method of simulating the area near the toes of the alluvial fans and edge of volcanic flows. In this respect, stream recharge by itself may not be a sensitive variable, but it does require a more complicated formulation of other parts of the ground-water model.

Underflow is small compared to other components of the water budget. Variations in the quantity of underflow from Chalfant valley result in slightly different quantities of evapotranspiration near Bishop and some gain or loss of water by the Owens River near Laws. The changes in hydraulic head are limited to an area close to the boundary. Part of the reason for this appears to be the the strong control exerted by the evapotranspiration function used in the ground-water model. As was observed when each of the other variables in the ground-water model was varied, evapotranspiration adjusts to minimize changes in hydraulic heads. The constant-head function used to simulate the Owens River acts in a similar, though more localized way. Therefore, effects caused by changes in the amount of underflow are not as evident in hydraulic heads as they are in the distribution and quantity of inflow and outflow.

Ground-water pumpage was assumed to be known and was not varied as a part of the sensitivity analysis. The method of simulating the interaction of the ground-water system with the Owens River, Los Angeles Aqueduct, and Tinemaha and Haiwee Reservoirs (constant hydraulic heads) does not allow for any adjustments except in the prescribed constant hydraulic head, which was assumed to be known. Therefore, sensitivity analysis was not done on this part of the ground-water model. 


\section{Discussion of Model Development and Results}

Valuable information was gained from the design, development, calibration, and sensitivity analysis of the preliminary ground-water model. These results are being used to guide other studies of the Owens Valley hydrologic system, in particular development of more detailed ground-water-flow models.

During design and development of the preliminary model, different methods of simulating the ground-water system were evaluated. Many of the findings from this study are observations about which methods appear to be most useful in simulating the Owens Valley ground-water system. During calibration and sensitivity analysis of the model, other critical aspects of simulating the ground-water system were identified. Areas where the model performed satisfactorily or unsatisfactorily were determined, as well as the variables that exert the greatest control on the model solution. A list of these observations and suggestions for future work is included in the section entitled, "Need for Future Studies."

The use of hydrogeologic categories to group areas with similar geologic materials was a simple technique that produced good results with two exceptions--the area along the toes of alluvial fans and the area along the edge of the permeable volcanic deposits (compare fig. 6 with fig. 8). In the area of the alluvial fans, it seems likely that the fan deposits grade into the stream-channel and deltaic deposits through a transition zone that was not defined or simulated. The material near the toes of alluvial fans may have different hydraulic properties because of reworking of the relatively coarse fan material by the Owens River and ancient Owens Lake. If such a zone can be documented, then incorporating it as an additional hydrogeologic category would probably improve future simulations. In the area of volcanic deposits, a discernible transition zone is less likely because the material was deposited in bulk in the form of a volcanic flow. Sorting and reworking would be 1 imited to small quantities of eroded volcanic material along the edge of a flow.

The areas along the toes of the alluvial fans are also characterized by a line of springs (springline) and the areas along the edge of volcanic deposits, by individual springs. Because these features were not simulated in the preliminary model, high simulated hydraulic heads in these areas may be partiy a result of not accounting for springflow. The relative abundance of water in these areas would indicate that evapotranspiration rates are probably higher than farther up on the fans or farther out on the valley floor. Simulation of these areas might be improved by locally increasing the maximum evapotranspiration rate. In addition, individual springs could be simulated using another type of discharge relation, such as the drain function described by McDonald and Harbaugh (1984). This function uses Darcy's law to calculate ground-water discharge whenever the hydraulic head in the ground-water system exceeds a prescribed altitude. Finally, numerical models do not simulate abrupt changes in hydrologic regimes we11, so the area along the edge of the volcanic deposits may continue to be poorly simulated regardless of the type of ground-water model or methods of simulating ground-water discharge. 
A few additional areas of the valley were simulated unsatisfactorily, in particular near Bishop Creek, east of the Alabama Hills, and northeast of Bishop near Chalfant Valley. Errors in these areas indicate a local imbalance of recharge, discharge, and aquifer parameters. Further calibration of the model would likely have produced satisfactory results in each area. Information on the gains and losses for the Owens River east of the Alabama Hills would aid in calibration of that area. Differences between measured and estimated data northeast of Bishop may indicate too much underflow from Chalfant valley.

One way to improve the model simulations, especially in key areas such as near the toes of alluvial fans, is to decrease the size of the model grid blocks. Abrupt changes in transmissivity or vertical conductance from one area to another can result in poor agreement between simulated and measured hydraulic heads. A finer grid spacing would facilitate more gradual changes in hydraulic parameters, which should produce a better simulation of the ground-water system. In some areas, such as those across faults, abrupt changes in transmissivity are real. Such areas are difficult to simulate in any finite-difference model, regardless of grid spacing; however, a preliminary evaluation of the major faults in Owens Valley suggests that they can be simulated satisfactorily if a somewhat finer grid is used. The effects of more localized faulting may have to be addressed by using models of specific areas at a much more detailed scale.

Present (1986) computer capabilities (Prime model 750 minicomputer) dictate the reasonable limits of decreasing the size of the valleywide model grid. Assuming that a transient simulation is required for a model with two layers and several recharge and discharge functions, the minimum size of a uniform grid is between 1,000 and 2,000 feet on a side. Variable spacing of the grid does not yield a significant improvement because of the geometry of Owens valley and location of critical hydrologic areas. Although models with a finite-element formulation use more efficient methods of discretization, large finite-element models are usually much more cumbersome to work with than finite-difference models. Many of the critical hydrologic features are located within a few thousand feet of each other. For example, in the Independence area, the toes of alluvial fans, the springline, the aqueduct, pumped wells, changes in vegetation from sagebrush to phreatophytes, and changes in transmissivity and vertical conductance are al1 found within 3,000 feet. Detailed investigation of these features will require models of local areas in addition to the valleywide model.

The two-layer conceptualization of the ground-water system produced satisfactory results. Although the match between measured and simulated hydraulic heads was determined to be less satisfactory in some areas of the valley (fig. 8), the general configuration of simulated hydraulic heads matched measured data for both unconfined and confined zones. The approximation of numerous individual clay layers by a single confining layer also appeared to yield satisfactory results. However, vertical conductance values for this layer cannot be verified because the values were determined entirely by trial-and-error adjustment during calibration of the model. In order to develop a range of likely values, local estimates from field measurements in Owens Valley would be needed. 
Both the spatial distribution and method of simulating stream recharge worked well in a steady-state analysis. Although hydraulic-head data are sparse for the upper slopes of alluvial fans, the general distribution of recharge along individual streams produced reasonable results in areas of known hydraulic heads. As indicated by figure 8 , additional work may be required in distributing recharge for the largest stream--Bishop Creek. A transient analysis also may require adjusting the temporal distribution of stream recharge. Because the depth between land surface and the water table varies considerably on the alluvial fans, a noticeable lag may occur between a measured loss of water in a stream and the resulting response of the groundwater system.

Numerical problems associated with increasing the recharge rate appear to be caused by the method of simulating the boundaries between hydrogeologic areas rather than by the recharge rate itself. A higher total recharge rate, as indicated by previous estimates, probably is numerically possible if suggested changes are made in model grid size, local evapotranspiration rates, and the method of simulating springflow. Of course, a commensurate increase in the valleywide evapotranspiration rate would have to be justified in order to maintain the steady-state water budget (see table 2).

Using constant-head conditions to simulate the interaction of the groundwater system with the Owens River, the Los Angeles Aqueduct, and Tinemaha and Haiwee Reservoirs was a useful simplification of the system for this preliminary analysis. However, a less restrictive approximation might be considered for future investigations. Head-dependent functions based on Darcy's law typically have adjustable parameters for the area of infiltration and the hydraulic conductivity of material between the surface-water body and the ground-water system. Including these parameters in the ground-water model would permit a more realistic approximation of the actual system and greater control over calibration of the ground-water model.

\section{Findings From Other Ground-Water Modeling Studies in Owens Valley}

other ground-water modeling studies have been conducted for parts of Owens Valley. Some of the findings from those studies are presented here in order to augment findings from this investigation.

D.E. Williams (1969) simulated the ground-water-flow system in the area between Tinemaha Reservoir and the Alabama Hills (fig. 1) by using a singlelayer model. He noted (p. 124) that "geologic and hydrologic control is noticeably lacking in the areas away from the center of the valley" and suggested that east-west cross sections be made at regular intervals in order to gain maximum geologic and hydrologic knowledge of the valley. He also suggested that additional pumping tests would help determine hydraulic properties of the aquifer system, particularly near production wells. 
Los Angeles Department of Water and Power (M.L. Blevins, Los Angeles Department of Water and Power, written commun., 1985) attempted to simulate the ground-water system in the Bishop area for the period of water years 1938-68. The model was never successfully calibrated, but it did indicate important deficiencies in the understanding of the hydrologic system. In particular, Los Angeles Department of Water and Power found that a two-layer model would be required to accurately simulate the ground-water system. In addition, the distribution of recharge and discharge in the area was complicated and difficult to simulate.

Yen (1985) developed a two-layer, finite-element model of the ground-water-flow system in the southern part of the valley from Tinemaha Reservoir to Haiwee Reservoir. The model was developed at the same time as the one described in this report and with close coordination between Yen and the author of this report. As a result, both models evolved from a similar conceptualization of the hydrogeologic system. Both models have similar nodal scales and use the same type of hydrogeologic areas. However, the finiteelement model was calibrated by using transient conditions.

The primary purpose of Yen's work was to develop and test methods of linking probability analysis with a ground-water-flow model. Yen used a simplified two-point probability model in which all uncertainties in the model were combined into three random variables that represent recharge and discharge, hydraulic conductivity, and storage coefficient. He determined that "reasonable confidence can be obtained from the model for simulated water tables in the central region of the basin where vegetation is sensitive to water-table depths" (Yen, 1985, p. 150-153). He commented, however, that this would be true only if there are no nearby active production wells and if recharge and discharge rates and hydraulic conductivity can be estimated within 50 percent of the true values. Because of the importance of accurately estimating discharge rates, especially evapotranspiration, Yen indicated that it would be desirable to link a detailed soil-moisture and evapotranspiration model to the ground-water model. He found that less confidence in the simulated results can be expected near the volcanic areas, near active production wells, and in the transition zone between the alluvial fans and center of the valley. In order to increase confidence near active production wells, a much finer discretization of the ground-water model would be required. Finaliy, Yen noted that the simulated results are relatively insensitive to uncertainty in the storage coefficient.

Two additional five-layer, finite-element, ground-water-flow models for Owens Valley were developed by the author of this report as part of this preliminary investigation. The model for the southern part of the valley had an identical grid to that of Yen's, but used a different formulation and computer code. The model for the northern part of the valley was designed as an extension of the southern one. The same style of grid design and the same method of simulating recharge and discharge were used. The models were joined at Tinemaha Reservoir by using no-flow and constant-head boundary conditions. The combined models covered the same area of Owens Valley as the valleywide, finite-difference model discussed in this report. 
The two finite-element models were similar to the valleywide finitedifference model in several fundamental ways. First, the models simulated the same period of time and used identical estimates of recharge and discharge. Second, the valley was divided into the same hydrogeologic areas. Third, the size of the individual finite-element or finite-difference blocks was similar although the shapes were different (triangular versus rectangular). Fourth, the same head-dependent relation was used to simulate evapotranspiration. The primary difference between the two finite-element models and the finitedifference model was that the finite-element models simulated the total thickness of alluvial and volcanic deposits in the valley and the finitedifference model simulated only the upper 1,000 feet of deposits.

By designing, calibrating, and comparing these different models, additional information was gained to help determine the best methods to simulate the Owens Valley ground-water system. In particular, it was determined that the size of the model grid blocks was too large to predict hydraulic heads with sufficient accuracy for a management model. Even in areas with sparse data such as on the alluvial fans and near Owens Lake, where the finite-element models used triangular blocks 2 to 3 miles on a side, the ability to change model parameters or to redistribute recharge and discharge was insufficient. Accurate simulations of transient conditions would require even smaller model blocks than simulations of steady-state conditions.

Steady-state simulations that use the total thickness of alluvial and volcanic deposits in Owens Valley did not produce substantially different results for the near-surface ground-water system. Transient simulations probably would be affected even less by aquifer materials more than 1,000 feet below land surface. Therefore, future ground-water-flow models of Owens Valley could probably exclude deep aquifer materials without a significant loss of accuracy. The finite-element models also included bedrock areas of Tungsten Hills, Poverty Hills, and Alabama Hills as part of the ground-waterflow system. It was hypothesized that these areas might transmit significant quantities of water through fractures or depositional layers. However, sensitivity analysis of the hydraulic conductivity and transmissivity of the bedrock areas showed that although some flow through fractures might occur, it is almost certainly negligible.

Separate simulation of the northern and southern parts of the valley produced unsatisfactory results. The dividing line near the Poverty Hills and Tinemaha Reservoir appears to coincide with a hydrologic divide for both the surface-water and ground-water systems and, as such, is a logical boundary for steady-state analysis of the two ground-water models. However, the complex geology and large ground-water and surface-water stresses in the area indicate that the entire area needs to be included in a single model, not used as a boundary between two models. It seems likely that the hydrologic divides are indeed present, but also that they migrate with time as a result of changes in the routing of streamflow on the alluvial fans and fluctuations in the location and quantity of ground-water pumpage. Accounting for such conditions would require a transient simulation. 
This preliminary evaluation of the hydrogeologic system in Owens Valley resulted in the following conclusions and suggestions for future work.

Hydrogeologic System

1. The geologic setting and history of Owens Valley are well documented; however, a better definition of some geologic factors that affect the ground-water system is needed. For example, the depth of unconsolidated deposits on the alluvial fans and under the volcanic flows has been only grossly defined, the location and extent of confining layers is largely unknown, and the hydrologic connection between Long Valley and Owens Valley has not been investigated.

2. Conceptualization of the ground-water-flow system, particularly in the vertical dimension, requires considerable improvement. The relative magnitude of the vertical and horizontal components of flow is not documented for the major types of aquifer materials or for critical areas of the valley, such as near production wells.

3. Isotopic analyses of ground water from different depths could be useful in determining the depth of ground-water circulation patterns.

Recharge and Discharge

4. A water budget for a recent period of time that reflects the current management of surface and ground water is needed. Previously published water budgets have been incomplete or have not included the current magnitude of ground-water withdrawals.

5. A set of consistent water budgets, including a surface-water budget, a ground-water budget, and a budget for the entire valley is needed. Ideally, the same items would appear in each budget to assure consistency and facilitate comparisons with numerical models of either the surface- or ground-water system.

6. Precipitation is well defined throughout the valley. Future measurements at selected stations are probably sufficient to define annual or possibly monthly rates of precipitation over most of the valley.

7. Additional discharge measurements for the Owens River would improve understanding of the interaction between the river and the ground-water system. Identification of gaining and losing reaches of the river is particularly important.

8. Estimates of streamflow and stream recharge are probably more accurate than any other component of the water budget except ground-water pumpage. The greatest uncertainty occurs in estimates of flow or recharge in ungaged areas of the valley. 
9. The potential importance of inflow through or under the Volcanic Tableland north of Bishop could be investigated with a fine-scale, transient ground-water-flow model. In order to do this, an accurate assessment of gains and losses for the Owens River near the Tableland would need to be made.

10. Evapotranspiration is the least defined component of the water budget. The most important new data needed to verify water budgets and ground-water-flow models would be actual measurements of evapotranspiration in representative areas of the valley floor.

11. The quantity of evapotranspiration from the higher parts of the alluvial fans is virtually unknown. Some field measurements would be helpful to verify the assumption used in this study that nearly all precipitation on alluvial fans is evaporated or transpired.

12. Quantifying the springflow that percolates to the ground-water system, is evapotranspired locally, or is added to the surface-water system would aid in developing water budgets for small areas of the valley. These local budgets would be helpful to verify the distribution of recharge and discharge used in future ground-water models.

13. Ground-water pumpage is well documented. However, the quantity of withdrawal from different zones of permeable material, for example from either side of a confining layer, has not been investigated.

14. More information has been gathered on the interaction of the ground-water system with the Los Angeles Aqueduct than on the interaction with the Owens River. Monitoring releases of water from the spillgates and measuring hydraulic heads in wells near the aqueduct need to be continued in order to verify concepts of local recharge and discharge.

15. The rates of underflow into and out of the Owens valley ground-water system from adjacent valleys is not known, but has been estimated by using Darcy's law. Verification of these estimates is possible by using a ground-water simulation model to test the effect of different flow rates on nearby hydraulic heads.

\section{Simulation of the Ground-Water System}

16. To calibrate and verify an improved ground-water-flow model, both a steady-state and transient period are needed that reflect hydrologic conditions in the valley after 1970 when water exports were increased.

17. Simulating the valleywide ground-water system as two layers produced satisfactory results. Detailed simulations of complicated areas, such as near permeable volcanic deposits, might require additional layers.

18. Round Valley can be excluded from future valleywide ground-water models. Although ground water does flow from Round Valley into Owens Valley, the volume and rate of flow can be estimated as accurately using Darcy's law as by including Round Valley, with its many unknown aquifer characteristics and rates of recharge and discharge, in the ground-water model. 
19. The location and boundary conditions used to simulate underflow of ground-water from Chalfant Valley produced reasonable results; however, the unsatisfactory match between nearby simulated and measured hydraulic heads may indicate that the assumed rate of underflow is too high.

20. The southern part of the ground-water model need not include Owens Lake. The high degree of uncertainty in local recharge and discharge rates in the vicinity of Owens Lake as well as in nearby aquifer characteristics limits the usefulness of including the area in a valleywide model. Unless watermanagement issues require that the area be included, a flow boundary on the south side of the Alabama Hills would be satisfactory.

21. In order to simulate ground-water flow satisfactorily in critical areas of the valley, a finer model grid is needed. Development of smaller area models may be useful in addition to a more detailed valleywide model. Improved spatial definition is most important in the transition zone where alluvial fan and volcanic deposits grade into stream-channel and deltaic deposits.

22. The computer code by McDonald and Harbaugh (1984) accurately simulated the Owens Valley ground-water system. More detailed simulations may require additional capabilities, such as algorithms to route streamflow or to calculate evapotranspiration from estimates of soil moisture and depth to water.

23. The probable range of aquifer characteristics, except vertical hydraulic conductivity, has been well defined. Further effort is needed to define the spatial distribution of these characteristics. This information is essential to develop more detailed concepts of ground-water flow and to verify patterns of aquifer parameters used in ground-water models. Estimates of aquifer characteristics are lacking on the alluvial fans and east of the Owens River.

24. A functional relation between evapotranspiration and plant, soil, and meteorological characteristics of Owens Valley needs to be developed and verified by using actual measurements of evapotranspiration. If hydraulic head of the saturated ground-water system is one of the variables in the relation, then a computational algorithm needs to be written and included as a subroutine in future ground-water-flow models.

25. Springflows were not simulated in the preliminary model, but need to be part of future simulations.

26. Interaction of the ground-water system with the Owens River and Los Angeles Aqueduct was simulated with constant-head conditions. Although this method produced reasonable results, future models would probably be improved by using head-dependent functions.

27. Calibrated values of transmissivity were slightly lower than initial estimates. Further analysis of well-documented pumping tests is needed to verify that the calibrated values are representative of the hydrogeologic system. 
28. The most sensitive parameter in the preliminary model was evapotranspiration. An improvement in estimates of evapotranspiration would produce the greatest improvement in the preliminary model and, presumably, substantial improvements in other ground-water models of Owens Valley.

29. Vertical conductance was a less sensitive parameter than initially expected, but it may be more important in transient simulations.

30. Preliminary simulation of the ground-water system was not satisfactory along the toes of alluvial fans and at the edge of volcanic deposits near Big Pine. Because these are important areas hydrogeologically and for water management, development of more advanced models needs to focus on simulating these areas as accurately as possible.

\section{SUMMARY AND CONCLUSIONS}

Owens Valley is a major source of water for southern California and presently (1986) provides more than 60 percent of the supply for Los Angeles. Streamflow into Owens Valley from the Sierra Nevada is captured at the base of the alluvial fans, diverted into the Los Angeles Aqueduct, and transported out of the valley. This supply can be augmented with ground-water pumpage from approximately 300 wells in the valley. Since 1970, ground-water withdrawals from Owens Valley have increased, and a decline in the health of vegetation has been reported. Because of rising concerns among the local residents who enjoy the Owens Valley environment and depend on tourism, litigation was begun by Inyo County against the city of Los Angeles over the reported ill-effects of ground-water withdrawals on vegetation. This litigation, in addition to counter-suits by the city of Los Angeles, was set aside pending the results of a 5-year cooperative study by Inyo County, Los Angeles Department of Water and Power, and the U.S. Geological Survey to investigate the hydrogeology and plant ecology of Owens Valley.

Objectives of the overall study include determining the sensitivity of vegetation to changes in water levels, measuring evapotranspiration, and simulating the use of water by plants. This information will be combined with results from hydrogeologic investigations in order to develop a valleywide hydrologic management model. As an initial part of this study, a preliminary ground-water-flow model was developed and used to evaluate present data and hydrologic concepts of Owens Valley. Results of this initial evaluation are being used to guide data collection and the development of more sophisticated hydrologic models.

Conclusions reached during this part of the study resulted from analysis of available data and present concepts of the hydrogeologic system and from steady-state simulations using the ground-water-flow model. During analysis of the hydrogeologic system, previously published water budgets were reviewed and found to be incomplete. In particular, no estimates of a surface-water budget were available. In addition, estimates of recharge to and discharge from the Owens River and the Los Angeles Aqueduct were available only for 
broad areas of the valley. The geologic and hydrologic controls on the ground-water system are qualitatively known, but quantitative estimates of important variables, such as vertical hydraulic conductivity, have not been made. In addition, the location and extent of confining layers is poorly documented. Although numerous estimates of evapotranspiration have been made, there has been no comparison of these estimates with actual field measurements of evapotranspiration for the phreatophytic shrubs that cover much of the valley.

Simulations of the ground-water system under steady-state conditions were used to identify areas of the valley where more detailed information is needed and hydrologic features that exert the greatest control on the ground-water system. During model calibration, two areas consistently produced unsatisfactory results--areas near the toes of alluvial fans and areas along the edge of permeable volcanic deposits. Both types of areas have abrupt changes in hydraulic properties of aquifer materials, springs or springlines, changes in the type of vegetation, and most of the production wells. Because of the importance of these areas in water-management decisions, future data collection and model investigations need to strive to improve understanding of the areas and methods of simulating the nearby ground-water-flow system. The ground-water-flow system in other areas of the valley either was simulated satisfactorily or preliminary evaluations indicate that it can be simulated satisfactorily with minor changes in model development or calibration.

Simulated recharge to and discharge from the aquifer are considerably lower than previous estimates. This difference results primarily from an assumption of lower recharge rates for individual streams and no recharge in ungaged areas. Because these simulated recharge rates may be too low, future investigations that use numerical models need to incorporate measured values of recharge for individual streams and evaluate estimates of unmeasured recharge with sensitivity analysis. The lower values of simulated discharge (primarily evapotranspiration) resulted directly from the lower recharge rates. Evapotranspiration was assumed to have a broad range of possible values and, therefore, was calculated as a residual in the steady-state water balance.

Sensitivity analysis of the model indicated that evapotranspiration is the variable that exerts the greatest control on the ground-water system. Because of this importance, future simulations need to use spatially distributed estimates of evapotranspiration in order to verify model results. Vertical hydraulic conductivity was found to be a less important variable than originally believed, but it may have a greater effect on transient simulations. Major faults in the valley appear to produce only localized effects on the ground-water-flow system. The bedrock areas in Tungsten Hills, Poverty Hills, and Alabama Hills effectively are impermeable parts of the ground-water system, and as such can be excluded from future modeling efforts. Round Valley and the area near Owens Lake do not significantly affect the accuracy of model results in the central part of Owens Valley and, therefore, probably can be excluded from future ground-water-flow models that focus on the area from Bishop to Lone Pine. 
Future investigations need to consider developing both valleywide and small area models. A valleywide model with the changes indicated in this report would have several important uses. First, it assures that local estimates of the water budget, aquifer characteristics, and hydraulic heads are all compatible throughout the valley. Second, in areas where data are sparse or uncertain, the model can be used to test the importance of additional information. Third, large-scale or long-term alternative water-management strategies can be evaluated for the entire ground-water system. Many details of the ground-water system, however, cannot be adequately represented with a valleywide model, except by using extremely large, expensive computer resources. Small area models, using boundary conditions derived from a valleywide model, could be an effective way to simulate local ground-water-flow systems and to investigate more detailed questions about water management.

\section{SELECTED REFERENCES}

Bateman, P.C., 1965, Geology and tungsten mineralization of the Bishop district, California, Gravity study of Owens Valley by L.C. Pakiser and M.F. Kane, Seismic profile, by L.C. Pakiser: U.S. Geological Survey Professional Paper 470, $207 \mathrm{p}$.

Bennett, G.D., Kontis, A.L., and Larson, S.P., 1982, Representation of multiaquifer well effects in three-dimensional ground-water flow simulation: Ground Water, v. 20, no. 3, p. 334-341.

California Department of Water Resources, 1960, Reconnaissance investigation of water resources of Mono and Owens basins, Mono and Inyo Counties: $92 \mathrm{p}$.

Conkling, Harold, 1921, Report on Owens Valley project, California: U.S. Reclamation Service, 86 p.

Dewiest, R.J.M., 1969, Porosity and permeability of natural materials, in Flow through Porous Media, edited by R.J.M. DeWiest: New York, Academic Press, p. 53-89.

Durbin, T.J., 1978, Calibration of a mathematical model of the Antelope Valley ground-water basin, California: U.S. Geological Survey Water-Supply Paper 2046, $91 \mathrm{p}$.

Durbin, T.J., Glenn, G.W., and Freckleton, J.R., 1978, Two-dimensional and three-dimensional digital flow models of the Salinas Valley ground-water basin, California: U.S. Geological Survey Water-Resources Investigations Report 78-113, $134 \mathrm{p}$.

Fenneman, N.M., 1931, Physiography of western United States: New York, McGraw-Hi11, 534p.

Freeze, R.A., and Cherry, J.A., 1979, Groundwater: Englewood Cliffs, New Jersey, Prentice-Hal1, Inc., $604 \mathrm{p}$.

Gilbert, C.M., 1938, Welded tuff in eastern California: Geological Society of America Bulletin, v. 49, no. 12, p. 1829-1862.

Griepentrog, T.E., and Groeneveld, D.P., 1981, The Owens Valley management report: Prepared for the County of Inyo, Bishop, California, $272 \mathrm{p}$. 
Hardt, W.F, 1980, Review of hydrologic information for adequacy in developing a water-management plan in the Owens Valley, southern California, Appendix B of Owens Valley ground-water investigation, Phase 1: Cal ifornia Department of Water Resources Southern District report, $77 \mathrm{p}$.

Knopf, Adolph, 1918, A geologic reconnaissance of the Inyo Range and the eastern slope of the southern Sierra Nevada, California, Stratigraphy of the Inyo Range, by Edwin Kirk: U.S. Geological Survey Professional Paper $110,130 \mathrm{p}$.

Lee, C.H., 1912, An intensive study of the water resources of a part of Owens Valley, California: U.S. Geological Survey Water-Supply Paper 294, $135 \mathrm{p}$.

Lee, W.T., 1906, Geology and water resources of Owens Valley, California: U.S. Geological Survey Water-Supply and Irrigation Paper 181, 28 p.

Lohman, S.W., 1979, Ground-water hydraulics: U.S. Geological Survey Professional Paper 708, $70 \mathrm{p}$.

Los Angeles Department of Water and Power, 1972, Report on water resources management plan, Owens Valley groundwater basin: $160 \mathrm{p}$.

1976, Increased pumping of the Owens Valley groundwater basin: Final Environmental Impact Report, v. 2, $125 \mathrm{p}$.

1978, Increased pumping of the Owens Valley groundwater basin: Draft Environmental Impact Report, 152 p., 8 app.

-.- 1979, Increased pumping of the Owens Valley groundwater basin: Final Environmental Impact Report, v. 1, $253 \mathrm{p}$.

McDonald, M.G., 1984, Development of a multi-aquifer option for a modular mode1: Proceedings of the NWWA conference on Practical Application of Groundwater Mode1s, Columbus, Ohio, August 15-17, p. 786-796.

McDonald, M.G., and Harbaugh, A.W., 1984, A modular three-dimensional finite-difference ground-water flow model, U.S. Geological Survey Open-File Report 83-875, $528 \mathrm{p}$.

Remson, Irwin, Hornberger, G.M., and Molz, F.J., 1971, Numerical methods in subsurface hydrology: New York, John Wiley, $389 \mathrm{p}$.

Pakiser, L.C., Kane, M.F., and Jackson, W.H., 1964, Structural geology and volcanism of Owens Valley region, California--A geophysical study: U.S. Geological Survey Professional Paper 438, $68 \mathrm{p}$.

Thornthwaite, C.W., 1931, The climates of North America according to a new classification: Geographical Review, v. 21, p. 633-655.

Todd, D.K., 1959, Ground water hydrology: New York, John Wiley, 336 p.

Tyson, N.H., and Weber, E.M., 1964, Groundwater management for the nations future: Computer simulation of groundwater basins: American Society of Civil Engineers, Journal of Hydrology, v. 90, no. HY4, p. 59-77.

Wang, H.F., and Anderson, M.P., 1982, Introduction to groundwater modeling: San Francisco, W.H. Freeman, $237 \mathrm{p}$.

Williams, D.E., 1969, Preliminary geohydrologic study of a portion of the Owens Valley ground-water reservoir: unpublished Ph.D. dissertation, New Mexico Institute of Mining and Technology, $194 \mathrm{p}$.

Williams, P.B., 1978, Changes in the Owens Valley shallow groundwater levels from 1970 to 1978: Prepared for the Inyo County Board of Supervisors, $50 \mathrm{p}$.

Yen, Chung-Cheng, 1985, A deterministic-probabilistic modeling approach applied to the Owens Valley groundwater basin: unpublished Ph.D. dissertation, University of California at Irvine, School of Engineering, $199 \mathrm{p}$. 